\title{
United States: 2006 Article IV Consultation-Staff Report; Staff Statement; and Public Information Notice on the Executive Board Discussion
}

Under Article IV of the IMF's Articles of Agreement, the IMF holds bilateral discussions with members, usually every year. In the context of the 2006 Article IV consultation with the United States, the following documents have been released and are included in this package:

- $\quad$ the staff report for the 2006 Article IV consultation, prepared by a staff team of the IMF, following discussions that ended on May 31, 2006, with the officials of the United States on economic developments and policies. Based on information available at the time of these discussions, the staff report was completed on June 30, 2006. The views expressed in the staff report are those of the staff team and do not necessarily reflect the views of the Executive Board of the IMF.

- $\quad$ a staff statement of July 24, 2006 updating information on recent developments.

- $\quad$ a Public Information Notice (PIN) summarizing the views of the Executive Board as expressed during its July 24, 2006 discussion of the staff report that concluded the Article IV consultation.

The document listed below has been or will be separately released.

\section{Selected Issues Paper}

The policy of publication of staff reports and other documents allows for the deletion of market-sensitive information.

To assist the IMF in evaluating the publication policy, reader comments are invited and may be sent by e-mail to publicationpolicy@imf.org.

$$
\begin{gathered}
\text { Copies of this report are available to the public from } \\
\text { International Monetary Fund • Publication Services } \\
70019^{\text {th }} \text { Street, N.W. • Washington, D.C. } 20431 \\
\text { Telephone: (202) 623-7430 • Telefax: (202) 623-7201 } \\
\text { E-mail: publications@imf.org • Internet: http://www.imf.org }
\end{gathered}
$$

Price: $\$ 15.00$ a copy

\section{International Monetary Fund Washington, D.C.}





\title{
INTERNATIONAL MONETARY FUND
}

\section{UNITED STATES}

\section{Staff Report for the 2006 Article IV Consultation}

Prepared by the Staff Representatives for the 2006 Consultation with the United States

\author{
Approved by Anoop Singh and Carlo Cottarelli
}

June 30, 2006

- The 2006 Article IV discussions took place in Washington, D.C. during April and May. The staff team comprised C. Towe (Head), T. Bayoumi, M. Mühleisen, R. Balakrishnan, V. Klyuev, K. Krajnyák, S. Ouliaris, and E. Tsounta (all WHD); P. Mills (ICM); A. Bhatia (MFD); P. Mullins (FAD); H. Lankes and J. Hallaert (PDR). Ms. Lundsager, Alternate Executive Director, and Ms. Pollard, Advisor (OED), also participated in the meetings.

- $\quad$ The Managing Director, the First Deputy Managing Director, Mr. Rajan (RES), Mr. Singh (WHD), and Mr. Moghadam (OMD) took part in the concluding discussions with outgoing Treasury Secretary Snow and Federal Reserve Chairman Bernanke on May 31. The mission also met with officials from the U.S. Treasury, Federal Reserve Board, Congressional Budget Office, Department of Health and Human Services, Federal Deposit Insurance Corporation, National Association of Insurance Commissioners, National Association of State Budget Officers, Office of the Comptroller of the Currency, Office of Management and Budget, Office of the U.S. Trade Representative, Pension Benefit Guaranty Corporation, and Securities and Exchange Commission. The team also met with financial and energy market participants, officials of the Federal Reserve Banks of Dallas and New York, and the New York State Insurance Department in February and March.

- $\quad$ The United States is a party to the convention on Combating Bribery of Foreign Public Officials in International Business Transactions and the Financial Action Task Force (FATF). An evaluation of the United States' compliance with FATF recommendations took place in 2006, with the report currently being finalized.

- U.S. authorities are developing a strategy to respond to an outbreak of an "avian flu" pandemic that includes preserving the functionality of the financial system. Financial institutions are expected to develop response plans based on government assumptions, and tests of the authorities' own preparedness are set to take place later in the year. Given the heavy reliance on remote computer access in case of an outbreak, the capacity of the communications infrastructure to provide sufficient bandwidth remains a critical factor. 


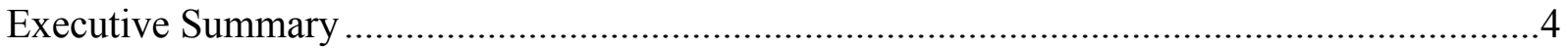

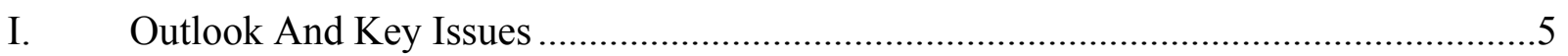

II. Monetary Policy: Maintaining Noninflationary Growth ……........................................

A. How Fast will Household Spending Slow? ……….........................................

B. Will Business Investment Surprise on the Upside? .............................................

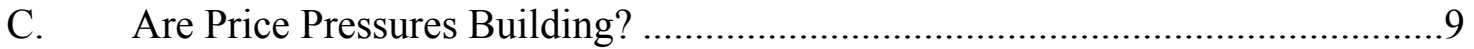

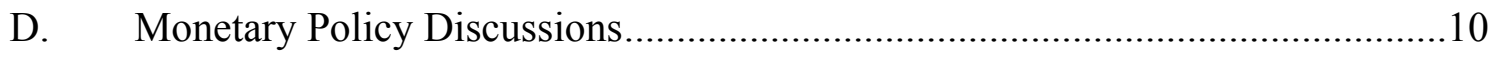

III. Preserving Domestic and External Financial Stability .................................................11

A. How Long will Benign Financing Conditions Continue? .....................................11

B. How Will the Current Account Deficit Adjust? ....................................................14

IV Fiscal Policy: Preparing For An Aging Population .....................................................

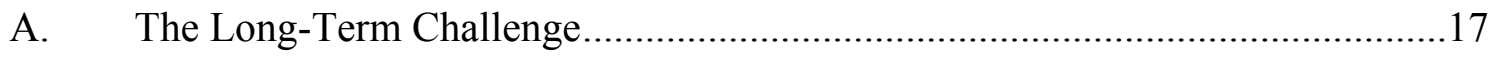

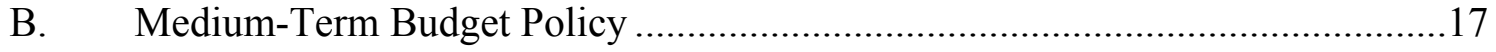

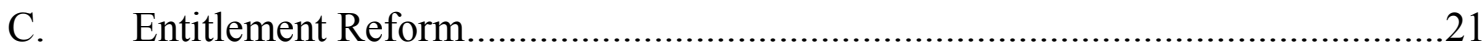

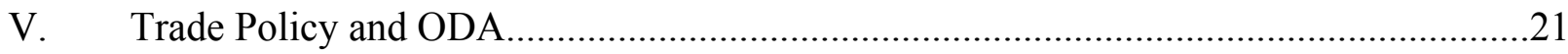

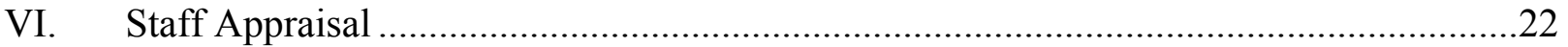

\section{Boxes}

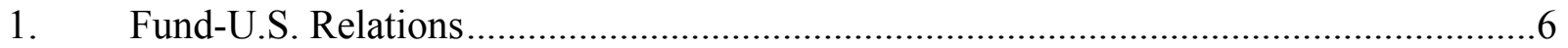

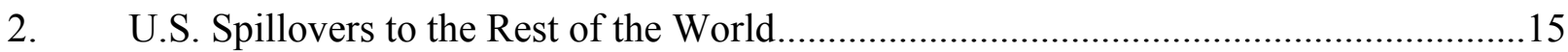

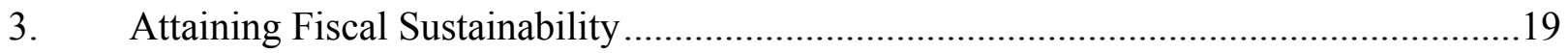

Tables

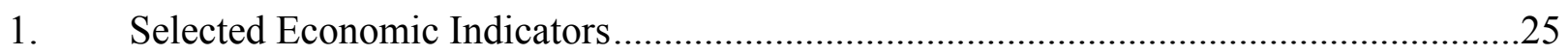

2. Economic Performance of Major Industrial Countries ……………………….............26

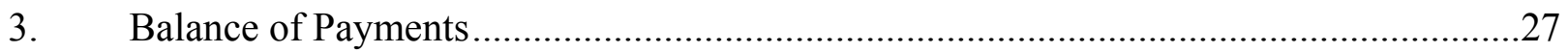

4. Indicators of External and Financial Vulnerability ……...............................................2

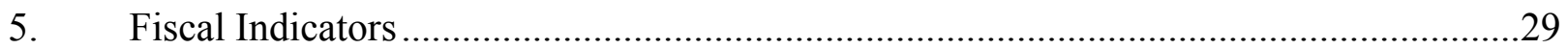

Figures

1. Economic Activity: Recent Developments and Outlook ………...................................30

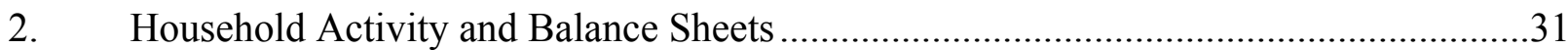

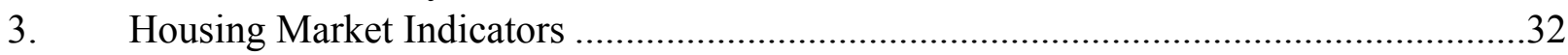

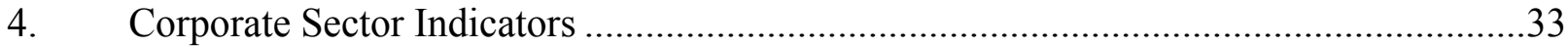

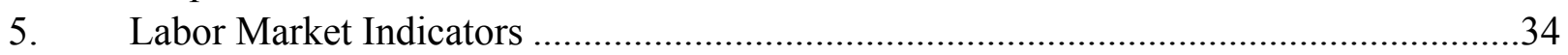

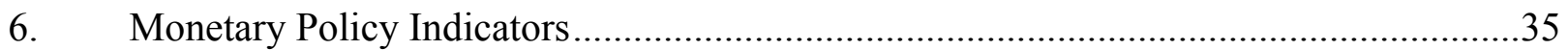




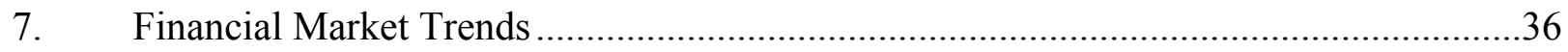

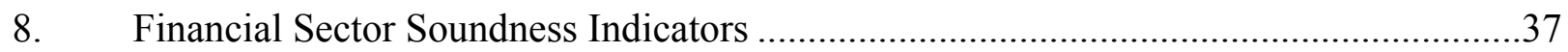

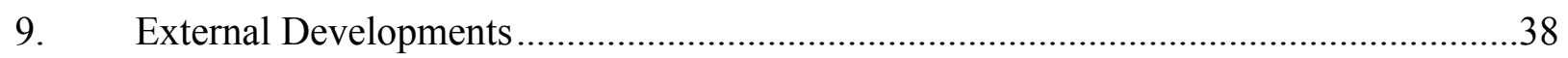

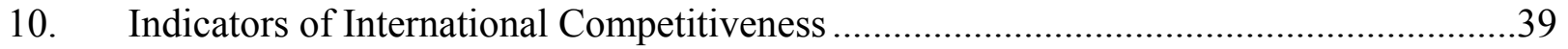

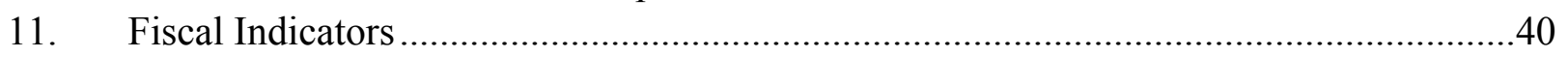

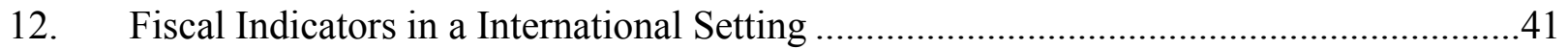

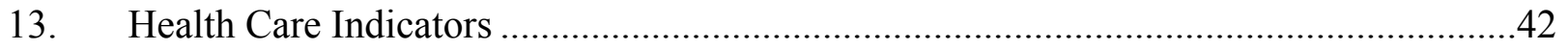

\section{Annexes}

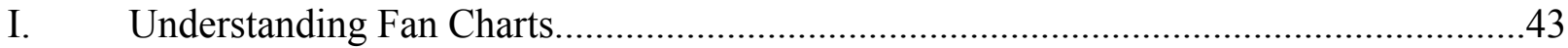

II. Summaries of background work issued as Working Papers ......................................44

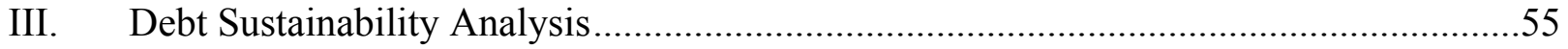

\section{Appendices}

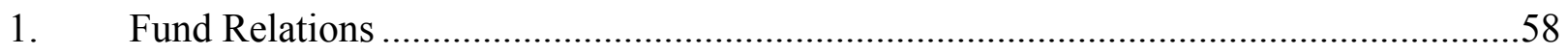

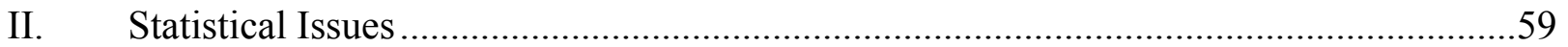




\section{EXECUTIVE SUMMARY}

The U.S. economy has remained a key engine of global growth, despite devastating hurricanes, a withdrawal of monetary stimulus, and high energy prices. Activity has remained robust, supported by strong productivity growth, and buoyant tax revenues seem likely to keep the FY 2006 federal deficit well below initial budget estimates.

The Federal Reserve will need to steer a delicate course between competing risks. A cooling housing market, higher energy prices, and an unusally low saving rate could weigh more heavily on activity than expected. However, given the recent pick up in core inflation and price expectations, policymakers have appropriately cautioned that some further policy firming may yet be needed. There would also seem merit in the Fed providing a more explicit statement of its inflation objective to help further anchor inflation expectations.

The U.S. financial sector has proven innovative and resilient in recent years. There are important areas where further reform could help enhance the financial system's strength and efficiency, including by tightening the supervision of the housing GSEs, moving to consolidate supervision and regulation of insurance companies, and reforming corporate pension plans. Publishing a regular Financial Stability Report and undertaking a Fund FSAP could provide further insights on these challenges.

Firm and vigorous implementation of the cooperative strategy laid out by the IMFC last April would support an orderly resolution to global imbalances. The United States has a major role to play in addressing this shared responsibility, and its main task remains to boost national saving, including by more ambitious fiscal consolidation. Achieving a balanced budget, excluding the Social Security surplus, within the next five years would set the federal debt ratio on a firm downward path and reduce the fiscal burden on future generations.

Although controlling outlays should remain central to deficit reduction, revenue measures should not be ruled out. There would seem merit in re-introducing caps on discretionary spending, as well as pay-as-you-go (PAYGO) requirements covering both entitlement spending and tax measures. On the revenue side, the priority should be on reforms that would broaden the revenue base by reducing tax preferences, but consideration could also be given to consumption-based indirect taxes.

It is critically important to re-invigorate the momentum for entitlement reform. Based on existing proposals, the challenge for policymakers is to form the necessary consensus to reform Social Security. Moreover, given the much larger financial shortfall of the Medicare system, fundamental reform of the U.S. health care system seems necessary.

Leadership by the United States remains key to global trade liberalization. Continued U.S. commitment is needed to ensure sufficient momentum for an ambitious conclusion to the Doha Round negotiations. Care will also be needed to resist domestic protectionist sentiment and to ensure that bilateral trade initiatives complement multilateral approaches. 


\section{OUTLOOK AND KeY ISSUES}

1. The U.S. economy has continued to be an engine of global growth despite monetary tightening and high oil prices (Figure 1). Over the last year, household spending remained robust, spurred by mortgage borrowing and double-digit house price inflation. However, with employment and wage growth remaining modest, the household saving ratio dropped into negative territory. As a result, and notwithstanding strong business saving and an improvement in the fiscal balance, the current account deficit reached a new record high.

2. Officials and staff both expect a "soft landing," with growth easing to potential and inflation remaining contained (Tables 1 and 2). ${ }^{1}$ The housing market is likely to cool in response to high valuations and tightening financial conditions, causing the impetus from consumption and residential investment to wane, but strong fundamentals should continue to support business investment. The external deficit is likely to remain wide, but the drag on activity from net exports will lessen as growth abroad strengthens. On the supply side, solid productivity growth should accommodate wage gains while containing price pressures.

\begin{tabular}{|c|c|c|c|c|c|c|c|}
\hline \multicolumn{8}{|c|}{$\begin{array}{l}\text { United States: Medium-Term Projections } \\
\text { (Percent change from previous period, unless otherwise indicated) }\end{array}$} \\
\hline & 2005 & 2006 & 2007 & 2008 & 2009 & 2010 & 2011 \\
\hline \multicolumn{8}{|l|}{ National production and income } \\
\hline Real GDP & 3.5 & 3.5 & 3.1 & 3.2 & 3.2 & 3.2 & 3.2 \\
\hline Total domestic demand & 3.6 & 3.7 & 3.1 & 3.1 & 3.1 & 3.1 & 3.1 \\
\hline Final domestic demand & 3.9 & 3.6 & 3.1 & 3.1 & 3.1 & 3.1 & 3.1 \\
\hline Private final consumption & 3.5 & 3.1 & 2.8 & 2.8 & 2.8 & 2.9 & 2.9 \\
\hline Net exports $1 /$ & -0.3 & -0.4 & -0.2 & -0.1 & -0.1 & -0.1 & -0.1 \\
\hline Unemployment rate (percent) & 5.1 & 4.8 & 4.8 & 4.8 & 4.8 & 4.8 & 4.8 \\
\hline CPI inflation & 3.4 & 3.2 & 2.6 & 2.5 & 2.5 & 2.5 & 2.5 \\
\hline Unified federal balance (Fiscal year) 2/ & -2.6 & -2.3 & -2.6 & -2.3 & -2.0 & -1.9 & -1.8 \\
\hline Current account balance 2/ & -6.3 & -6.5 & -6.7 & -6.7 & -6.7 & -6.7 & -6.7 \\
\hline \multicolumn{8}{|l|}{ Memorandum items: } \\
\hline Partner country growth & 2.8 & 3.2 & 2.9 & 2.9 & 2.8 & 2.8 & 2.8 \\
\hline Oil prices (\$/Barrel) 3/ & 53.4 & 66.5 & 69.8 & 68.5 & 67.5 & 66.8 & 66.0 \\
\hline $\begin{array}{l}\text { Sources: Haver Analytics; and Fund sta } \\
\text { 1/ Contributions to growth; NIPA basis, } \\
\text { 2/ In percent of GDP. } \\
\text { 3/ Average petroleum spot price: simple }\end{array}$ & $\begin{array}{l}\text { f estima } \\
\text { goods a }\end{array}$ & $\begin{array}{l}\text { nd servi } \\
\text { nis. }\end{array}$ & es. & ubai & Wes & yas & \\
\hline
\end{tabular}

3. Staff and officials also concurred on the sources of macroeconomic uncertainties, but had somewhat different perceptions of the balance of risks (Figure 1 shows fan charts, whose construction is discussed in Annex I):

\footnotetext{
${ }^{1}$ Box 1 summarizes the United States' relations with the Fund.
} 


\section{Box 1. Fund-U.S. Relations}

The United States and the Fund enjoy a close relationship, reflecting a consensus on the fundamental factors underpinning growth in market-based economies. Chief among those are a commitment to free trade, the strong role of property rights and sound institutions, flexible labor and product markets, a deep financial system, a relatively small size of government, and a high degree of transparency of economic policy decisions.

Within this broader consensus, both sides have taken different views on the amount of U.S. fiscal adjustment needed to prepare for population aging and the role of tax policy. While both sides agree that entitlement reform is key to long-term sustainability, the Fund has been advocating a more determined effort at fiscal consolidation to prepare for population aging. The Administration aims to reduce the deficit to around its long-term average of 11/2-2 percent of GDP, and has ruled out revenue measures to achieve more ambitious deficit reduction.

The authorities also remain skeptical about the role of U.S. fiscal policy in reducing global current account imbalances. The authorities commended bilateral surveillance of the United States for integrating analysis from the Fund's World Economic Outlook and other sources. ${ }^{1}$ However, they have discounted staff arguments that fiscal adjustment in the United States by itself could contribute significantly to an orderly adjustment of global current account imbalances, presenting their own analysis to suggest that the U.S. current account deficit is relatively insensitive to U.S. fiscal policy. ${ }^{2}$

Nevertheless, the United States has been a key voice for strengthening the role of the Fund in resolving global imbalances. Treasury officials have called on the Fund to strengthen its surveillance over members' exchange rate policies and have supported the introduction of multilateral consultations, reflecting the authorities' view that the resolution of global current account imbalances is a shared responsibility.

U.S. legislation has also been seeking to promote sound economic policies internationally through the work of the Fund. The U.S. Executive Director is obliged to pursue slightly more than 70 legislative mandates (as of August 2005) prescribing U.S. policy goals at the Fund, ranging from exchange rate stability to strengthened financial systems, good governance, AML/CFT, and U.S. voting positions on assistance to individual borrower countries. Progress toward these goals is evaluated in annual reports by the U.S. Treasury and the U.S. Government Accountability Office (GAO) to Congress. ${ }^{3}$

The authorities' agreement to discuss the modalities of a Financial Sector Assessment Program (FSAP) provides a welcome recognition of the Fund's work on financial sector soundness. The United States is the last G-7 country yet to agree to an FSAP, which has been a long-standing recommendation by staff.

1 "Working with the IMF to Strengthen Exchange Rate Surveillance," Remarks by Under Secretary for International Affairs Tim Adams at the American Enterprise Institute, February 2, 2006.

${ }^{2}$ See M. Barth and P. Pollard, "The Limits of Fiscal Policy in Current Account Adjustment," Department of the Treasury, Office of International Affairs, Occasional Paper No. 2, 2006.

${ }^{3}$ See "Implementation of Legislative Provisions Relating to the International Monetary Fund: A Report to Congress," Department of the Treasury, November 2005. 
- Staff considered risks to growth to be on the downside. The possibility of a more abrupt slowdown in the housing market, possible disappointments on the productivity front, and a disorderly adjustment to global imbalances more than offset the upside potential for business investment. Further, more difficult to quantify downside risks stemmed from avian flu and geopolitical events. Officials regarded risks as relatively balanced as they were more sanguine about the potential impact of the housing slowdown on spending and placed greater weight on upside potential from business investment, exports, and productivity.

- Staff suggested that the risks to inflation were on the upside. These stemmed largely from supply effects, including the possibility of a larger-than-anticipated productivity slowdown pushing up unit labor costs and the potential for pass-through of high commodity prices. Federal Reserve officials acknowledged the risks from commodity prices but were less concerned about downside risks to productivity growth.

4. Against this outlook, growing global current account imbalances, and the imminent retirement of the "baby boom" generation, the discussions focused on:

- Maintaining noninflationary growth. With policy interest rates having risen to around neutral, and output and inflation risks somewhat skewed, monetary policy decisions had become more delicately balanced.

- $\quad$ Preserving domestic and external financial stability. For example, U.S. policies could reduce risks from financial market volatility stemming from a disorderly resolution of global external imbalances.

- $\quad$ Preparing for an aging population. This involves reforming unsustainable entitlement programs and potentially pursuing more forceful medium-term public debt reduction to cope with spending pressures as the baby boom generation retires.

\section{Monetary Policy: Maintaining Noninflationary Growth}

\section{A. How Fast Will Household Spending Slow?}

5. Household spending has been the main driver of the expansion, boosted by the housing boom (Figure 2). With capital gains - particularly on houses - boosting personal wealth, real consumption and residential investment spending has grown an average $1 / 2$ percentage point faster than GDP since the 2001 recession. Real disposable income growth has been held back by rising energy prices and lackluster employment growth, and household saving turned negative as spending was financed in part through home equity withdrawal (HEW), which rose to a record 8 percent of U.S. personal income in 2005.

6. Staff and officials agreed that easy financing conditions and flexible U.S. financial markets had supported the housing market and contributed to a record housing equity withdrawal (HEW) ratio (Figure 3). Mortgage securitization had helped channel foreign savings into the U.S. housing market while allowing mortgage originators greater flexibility 
to diversify credit exposures and reduce systemic risk. Innovative mortgage instruments, low refinancing costs, and access to tax-advantaged home equity loans, had also supported HEW.

7. Staff observed that, while conditions varied across regions, U.S. house prices seemed overvalued and a correction appeared to have started (Chapter 1 of the Selected Issues paper suggests house prices are 15-20 percent above equilibrium). Fed officials did not disagree with this assessment but cautioned that such estimates were subject to considerable uncertainty and varied considerably across models. Moreover, empirical evidence suggested that the impact of personal income and employment conditions on house prices tended to dominate that of long-term interest rates, suggesting that less favorable financing conditions were unlikely to represent a significant shock to prices. $^{2}$

\section{Staff and officials agreed that a cooling in the housing market was likely to} dampen consumption and residential investment. The mission suggested that, with real house price inflation likely to halve to 5 percent in 2006 (yoy)and decelerate further subsequently, the increasing use of HEW and nontraditional mortgages implied that the sensitivity of consumption to a change in housing wealth would probably be at the upper end of the usual estimate of 3-7 cents per dollar. Once the impact on residential investment was added, this implied a reduction in GDP growth of around $1 / 2$ percent of GDP over the next two years (Annex I). Background work, summarized in Annex II.1, illustrates that in the U.K. and Australia, countries that experienced HEW ratios similar to that in the United States in recent years, slowing house price inflation led to a manageable rebound in household saving.

9. Staff viewed the balance of risks for household spending and residential investment as being on the downside. A faster deceleration in house prices could further amplify the impact on consumer and residential spending by eroding confidence and increased the strain on borrowers. These risks were exacerbated by the negative household saving rate and continued high energy prices that reduced discretionary spending power. Fed officials responded that, given the surprising strength of consumption over many years, smaller effects from slowing house prices and high energy costs were also possible.

\section{B. Will Business Investment Surprise on the Upside?}

10. Fed officials viewed the recent strength of business investment as consistent with underlying fundamentals. While business investment had been weak in the aftermath of the IT bubble, officials viewed the trends in the capital/labor ratio and other indicators as suggesting that any post-IT bubble overhang had been worked off. Continuing declines in capital goods prices and strong demand had made capital accumulation attractive even as interest rates had become less stimulative. As a result, purchases of (especially IT) equipment and software had accelerated to levels not seen since the late-1990s. Real growth in structures had been less strong and, given high office vacancy rates, officials expected this trend to continue.

\footnotetext{
2 Private sector analysts projected a relatively small short-term impact on the ratio of debt payments to income from upward movements in variable mortgage rates on adjustable rate mortgages and nontraditional mortgages.
} 
11. Officials and staff agreed that business investment could surprise on the upside. In line with global trends, the corporate sector had used high profits and low interest rates to strengthen balance sheets - including through equity buybacks - and accumulate large cash holdings, taking on the unusual position of a net lender (Figure 4). ${ }^{3}$ Although an expected weakening in consumption growth could have some dampening effect on business spending, extremely strong fundamentals - the near-record profit rate, healthy expected earnings growth, low leverage, and the still low cost of capital—suggested upside risks dominated.

\section{Are Price Pressures Building?}

\section{Fed officials acknowledged that the recent uptick in core inflation had been}

discouraging. The unemployment rate-at $43 / 4$ percent in April- had fallen to the low end of most estimates of the NAIRU, and capacity utilization was around its long-run average. Nevertheless, unit labor cost increases had been contained, reflecting solid productivity growth and modest wage gains. Officials noted that the absence of wage pressures could indicate a lower level of the NAIRU, although other structural factors, including globalization, could also have played a role. Staff analysis (summarized in Annex II.2) suggests that low inflation in recent years has largely reflected a larger-term downward trend. This has been somewhat reinforced by cyclical factors, including through globalization, that could reverse as the domestic and global environment evolves. ${ }^{4}$

13. Officials expected wage pressures to pick up over the coming year, but did not anticipate much pass-through to overall inflation. The post-2000 drop in labor market participation (discussed in Chapter 2 of the Selected Issues paper) was unlikely to be reversed. Thus, low unemployment could eventually lead to a pick-up in wage growth and some recovery of the labor share of national income (Figure 5). ${ }^{5}$ However, this would not necessarily translate into inflation, given strong productivity growth and room for downward adjustments to profit margins.

\section{Officials also observed that the boom in commodity prices implied a short-term} inflation risk. Energy prices now seemed to be feeding into inflation expectations, and this process might not yet be complete even if energy prices remained at their present level. While the impact of higher oil prices on the economy had been smaller than in the past, partly reflecting the reductions in oil intensity of production and productivity growth (staff analysis is contained in Chapter 3 of the Selected Issues paper), there continued to be a risk

\footnotetext{
${ }^{3}$ See Chapter 4 of the April 2006 World Economic Outlook.

${ }^{4}$ Chapter 3 of the April 2006 World Economic Outlook contains a multilateral discussion of globalization and inflation.

${ }^{5}$ Chapter 2 of last year's Selected Issues paper analyzes international trends in labor's share of national income.
} 
of price shocks related to bottlenecks in some key segments of the U.S. energy infrastructure. $^{6}$

\section{Monetary Policy Discussions}

\section{The technical discussions took place before the increase in financial market} volatility of May-June and the associated heightened concerns voiced about inflation, including by senior Fed officials. The global sell-off of riskier assets - most notably global equities and emerging market bonds-confirmed incipient evidence that the credit cycle was turning but has not had a significant impact on private sector assessments of U.S. growth prospects or financial vulnerabilities.

16. At the time of the meetings, staff suggested that, at 5 percent, the federal funds rate was close to most estimates of a neutral level (Figure 6). With inflation risks on the upside, however, a "risk management" approach to monetary policy-which took into account both the likely path of the economy and the risks around that path - could suggest the need for some further tightening, consistent with market expectations of a further rise in the federal funds rate by 25 basis points in subsequent months.

\section{Officials responded that the direction of future policy decisions had become much} less certain than earlier, when the federal funds rate was well below the neutral range. The May 10 Federal Market Open Committee (FOMC) statement reflected these considerations, noting that while "a further policy firming may yet be needed to address inflation risks ... the extent and timing of any such firming will depend importantly on the evolution of the economic outlook as implied by incoming information." Reflecting heightened inflation concerns, the FOMC raised the Fed funds rate to 51/4 percent on June 29 and the accompanying statement observed that while "some inflation risks remain ... any additional firming will depend on the evolution of the outlook for both inflation and economic growth."

18. Fed officials noted that policy decisions were complicated by uncertainty about the factors contributing to low long-term bond yields. If low term premiums reflected a shift in portfolio preferences toward long-term assets-possibly in response to the "great moderation" in macroeconomic volatility in recent decades - short-term interest rates would need to be higher than otherwise to offset the boost to demand from lower long rates. Conversely, if low term premiums reflected a weakening of global investment demand or higher global saving that helped contain domestic price pressures, a tightening would not be warranted.

\section{They observed that the impact of global financial market integration on the} monetary transmission mechanism was equally difficult to assess. Staff suggested that increased integration of national bond markets could help explain the muted rise in long-term interest rates and the correspondingly subdued response of demand components to U.S.

\footnotetext{
${ }^{6}$ Recent hurricanes have underlined structural weaknesses in the U.S. energy industry, including heavy reliance on Gulf Coast facilities and slow growth in refinery capacity. There are also increasing signs of strains in the electricity sector, as discussed in Chapter 4 of the Selected Issues paper.
} 
monetary tightening. Officials responded that it was difficult to gauge how the monetary transmission mechanism had changed in recent years, but they noted that recent movements in long-term interest rates seemed to reflect a relatively accurate anticipation of the pace and timing of Fed tightening, and the response of demand to these interest rate movements was consistent with past trends.

20. Fed officials did not see rising commodity prices as reflecting broader global inflationary pressures. Rather than a symptom of abundant global liquidity-including through easy U.S. monetary policy - officials viewed the commodity price boom as reflecting a relative price shift in response to rapid growth in commodity intensive countries, such as China. While the global economy might be hitting some bottlenecks, there was little sign of generalized pressures on resources. Rather, fast productivity growth in emerging markets had limited cost increases of their products and the ability of producers elsewhere to pass through higher commodity prices.

21. The mission suggested that the present conjuncture seemed propitious for the Fed to define its inflation objective more explicitly. Fed officials responded that a committee headed by Vice-Chairman Kohn had been established to examine the Fed's overall communication policy, including refining the definition of stable prices. Before such a refinement could occur, however, it would be necessary to establish a consensus that, by lowering inflation uncertainty, such a move would also be helpful in achieving the other objectives defined in the Federal Reserve Act (maximum employment and moderate longterm interest rates). Staff also suggested it could be helpful to increase the frequency and forward-looking element of the biannual Monetary Policy Report, to which officials responded that it would be difficult given the size and diversity of the FOMC.

\section{Preserving Domestic and External Financial StabiLity}

\section{A. How Long Will Benign Financing Conditions Continue?}

\section{Discussions of financial sector developments centered on the implications of the} rapid pace of change in the structure of U.S. financial markets (Figure 7). Officials observed that low credit spreads partly reflected the effectiveness of securitization and credit risk transfer techniques for improving the pricing and allocation of credit risk, especially for asset classes with higher risk profiles. ${ }^{7}$ The increased activity of hedge funds had enhanced price discovery and liquidity in many of the new markets. However, they agreed with the mission that some markets had yet to be fully tested in a less benign financial environment.

\section{Officials observed that banks had been remarkably adept in responding to}

changing market conditions. Although banking margins had been squeezed by the flattening of the yield curve, profitability had been sustained by non-interest income and low charge-off rates, notwithstanding the impact of Hurricane Katrina and a spike in personal bankruptcies in late 2005 ahead of changes to the bankruptcy code. While bank revenues remained

\footnotetext{
${ }^{7}$ Discussed in various Global Financial Stability Reports and Calvin Schnure "Boom-Bust Cycles in Housing: The Changing Role of Changing Financial Structure,” IMF Working Paper 05/200.
} 
dependent on the real estate market, even small and regional banks had traded parts of their

loan book against mortgage-backed securities, reducing their vulnerability to regional shocks.

\section{Staff and officials agreed that a range of indicators suggested that systemic risks} were at a low ebb (Figure 8):

- Distance-to-default measures for "large complex banking groups" (LCBGs, discussed in more detail in Chapter 5 of the Selected Issues paper), the "big five" investment banks, and the insurance sector had recovered to levels last seen in the mid-1990s. Default risks were largely confined to declining industries (the auto and airline sectors are discussed in Chapter 6 of the Selected Issues paper).

- Value-at-risk and implied default risk measures were low despite upticks after the May 2005 automotive industry rating downgrades and a large insurer's admission of accounting inaccuracies in late 2004.

- $\quad$ Capital adequacy remained strong across the banking sector, reflecting high profitability in recent years.

25. Staff and officials agreed, however, that increased risk-taking could foreshadow some deterioration in credit quality. U.S. corporate credit markets remained strong, supported by sustained brisk earnings growth, and credit spreads were low. However, staff observed that ample liquidity had begun to facilitate a pickup in mergers and acquisitions as well as leveraged buyout activity, while easier bank lending conditions had allowed loan leverage ratios to rise to levels last experienced in 1997. These trends could signal a turn in the credit cycle, leading to increased market volatility and widening corporate credit spreads. Subsequent to the discussions, a rise in equity market volatility in May and June was accompanied by a global sell-off of riskier assets, although the impact on corporate bond spreads has been modest.

\section{Financial sector risks related to household borrowing appeared relatively} manageable. With bank exposures increasingly concentrated in the household sector, officials felt that recent regulatory guidance tightening standards for home equity lending and nontraditional mortgages had already led to tighter credit conditions in those markets. Moreover, stress tests indicated that borrowers at risk of significant mortgage payment increases remained a small minority, concentrated mostly among higher-income households that were aware of the attendant risks. Officials acknowledged, however, that for banks with high concentrations of commercial real estate and construction loans on their books, sustaining revenues in the case of a downturn could be difficult. Staff observed that there was a risk of a significant dent in banking profitability if the housing market slowed abruptly.

\section{Officials acknowledged that regulators were facing a challenge to respond to the} rapid evolution of the financial system. They emphasized that - with markets becoming more complex and decentralized - supervisors could no longer track risk exposures on a system-wide basis, but instead needed to ensure that controls and procedures at systemically important institutions and infrastructure providers were robust. Given the increasingly 
complex structure of bank's operations, traditional supervisory activities were being augmented by a stronger analytical focus on large banks and critical market segments.

\section{Specific regulatory issues covered during the discussions included:}

- Hedge funds. Fed officials noted that leverage and concentration indicators of hedge funds had moderated, and that their trading strategies were more diverse than in the period leading up to the LTCM crisis. The mission broadly agreed with their view that hedge fund market activities were too fluid for direct regulation to be effective, and that supervisors - both in the United States and abroad - needed to focus instead on measures to limit counterparty risk to banks acting as prime brokers and to continue to improve the financial infrastructure. ${ }^{8}$

- Government-sponsored enterprises (GSEs). Staff and Treasury officials agreed on the need for rules to reduce the size of GSEs' own portfolios given the systemic risks they posed to the financial system. Officials were cautiously optimistic that the Administration's proposals to create a new regulator, establish risk-based capital requirements, and limit GSEs' portfolios would gain congressional support in 2006. Using the Treasury's ability to limit GSE debt issuance remained a second-best alternative, as it could encourage these institutions to accept greater risks to maintain profitability.

- Basel II. Bank regulators expected some decline in minimum capital requirements after the shift to Basel II norms in 2009. They acknowledged that the impact on bank balance sheets was uncertain, in part because the role of the economic cycle would only become fully evident after the system was implemented. However, capital adequacy standards could be recalibrated, if necessary, as the transition to the new framework was to take place over several years.

- Insurance regulation. Officials observed that the Administration had recently flagged the need for a stronger federal role in insurance regulation, which was presently a state responsibility. Staff supported this suggestion given the sector's systemic importance, increasing globalization, and the potential for regulatory arbitrage across jurisdictions. Officials noted that similar considerations could argue for some consolidation in the regulation of some segments of the financial sector (including banks), although specific proposals were not under consideration.

- Industrial Loan Companies (ILCs). Federal Reserve officials reiterated their concern that large commercial firms owning ILCs-some of which had evolved into sophisticated financial institutions - were not subject to consolidated supervision provisions under the Bank Holding Company Act. To protect the principle of

\footnotetext{
${ }^{8}$ Reflecting its focus on investor protection, the SEC proposed a rule requiring the registration of U.S. hedge fund advisers to improve controls and record-keeping systems. However, this regulation was struck down by the courts in June of this year.
} 
- $\quad$ consolidated supervision over banking operations, the mission agreed that ILCs should be limited in their ability to establish nationwide branch networks.

29. The mission suggested that a Fund Financial Sector Assessment Program (FSAP) might be a useful vehicle for providing an international perspective on these issues. Treasury and Fed officials responded that they were open to participating in an FSAP, and indicated interest in discussing specific modalities. The team also asked whether publishing a Financial Stability Report - as prepared by many other central banks or financial sector supervisors - might improve the market's understanding of U.S. financial risks and vulnerabilities. Fed officials responded that such a report would not add much value to what was already being published by regulators and market participants.

30. The team welcomed Administration proposals to strengthen defined benefit (DB) plans. Officials explained that current workers seemed to be accumulating retirement assets at a pace comparable to previous generations but, given the unfunded liabilities of many DB plans and the Social Security system, maintaining living standards past retirement could become more challenging. Proposals included reducing disincentives for overfunding of plans, using corporate bond yields to calculate pension liabilities, and allowing the Public Benefit Guaranty Corporation (PBGC) to set risk-based premiums. On the accounting side, officials were confident that a pending proposal by the Financial Accounting Standards Board (FASB) to include pension accounts in corporate balance sheets would lead to greater transparency and could help improve plan funding.

31. Staff and officials agreed that automatic enrollment in employer sponsored defined contribution plans with rising contribution schedules could help boost personal saving. Officials were seeking to amend pension regulations so that workers could be automatically enrolled in such plans, but legislation might be required to protect employers from legal sanctions that might arise if the return on pension investments disappointed. Officials observed that tax incentives, such as the lifetime saving accounts (LSAs) proposed in the budget, could also stimulate personal saving, but acknowledged that the net impact on national saving might be small in the absence of offsetting deficit-reduction measures.

\section{B. How Will the Current Account Deficit Adjust?}

32. The current account widened to a record $61 / 4$ percent of GDP in 2005, owing to higher oil prices and the relative strength of U.S. import demand (Figure 9 and Tables 3 and 4). In addition, staff analysis suggests that the shift in U.S. trade toward low-cost producers had blunted some of the measured real effective exchange rate depreciation in recent years (Figure 10 and Box 2 in last year's Staff Report). Nonetheless, the U.S. net foreign liability (NFL) position barely deteriorated in 2005, reflecting the effects of the relative strength of foreign equity markets on U.S. residents' investments, although recent financial market developments may have reversed some of these gains. 


\section{Box 2. U.S. Spillovers to the Rest of the World}

With the world's largest economy and most dominant financial markets, the U.S. has large significant spillovers on other countries :

- $\quad$ Real activity. Past WEO forecast errors (available since 1990) suggest that an unanticipated 1 percent undershoot in U.S. growth is associated with a $1 / 4$ percent slowing in growth elsewhere, with the largest effects being on countries with close trade and financial links. This may underestimate the effect of U.S. growth on the rest of the world, given the possible offsets provided by large non-U.S. shocks in the 1990s — such as the Asian crisis and German unification.

- $\quad$ Financial markets. U.S. financial markets retain their global dominance, for example dollar assets represent about half of global private sector bonds. Recent studies find that shocks to U.S. long-term real interest rates continue to flow through to foreign rates, including to major regions such as the euro area, and emerging market bond spreads appear particularly closely linked to U.S. financial conditions (see Box 1.5 of the April 2006 Global Financial Stability Report). In addition, rising gross international investment positions have increased the potential for wealth spillovers from changes in the dollar and U.S. asset prices (Annex II.4). Finally, U.S. financial market conditions have a direct impact on countries that link their exchange rates to the U.S. dollar.

- External indebtedness. Most analysts agree that while the size of U.S. net international liabilities are not currently a concern they are growing at an unsustainable rate. While many see a significant - and possibly abrupt — adjustment of the dollar as being necessary to correct this trend, with attendant risks for global growth and financial stability (as discussed in the World Economic Outlook), others have suggested that the resolution could come through a gradual adjustment of global saving and investment balances with more limited impacts on exchange rates.

U.S. monetary and fiscal policies also have international spillovers although the size of their impact remains a subject of controversy. Global Financial Stability Reports have discussed how abundant international liquidity - partly reflecting the stance of the Fed-has put downward pressure on global bond yields and supported a search for yield. In addition, analysis in the World Economic Outlook and elsewhere has estimated the impact of U.S. fiscal deficits on U.S. and global saving, external imbalances, and global real interest rates.

U.S. policies often matter more for other countries than domestically. A good example of this is the proposal by the President's Tax Reform commission to move from taxing worldwide corporate earning to a territorial system, which has generated almost no discussion at home but could significantly increase global tax competition. Staff analysis of this subject is discussed in Annex II.5. 
33. Officials agreed that the current account deficit seemed likely to widen further. Although the pickup in activity in Europe and Japan would support the trade balance, the large gap between exports and imports meant that exports needed to grow almost twice as fast as imports simply to keep the deficit unchanged. This could be difficult to achieve given that most estimates placed the income elasticity of U.S. imports as up to double the size of that for exports. Growing foreign indebtedness and rising U.S. interest rates also meant that debt dynamics were adverse, with the investment balance expected to turn negative in 2006.

34. The staff noted that the real exchange rate appeared significantly overvalued, especially given the projected deterioration of U.S. net foreign liabilities (see Annex III). A staff assessment using macroeconomic fundamentals estimated the overvaluation in the 15-35 percent range. Officials cautioned that such estimates were highly sensitive to underlying assumptions, markets were best placed to judge appropriate exchange rate levels, and foreign investors showed no signs of becoming less willing to invest in U.S. markets. In this context, they expressed concern that exchange rate inflexibility and other factors were impeding needed adjustment in many countries' competitiveness.

35. Officials remained relatively sanguine about the risk of a disorderly adjustment. U.S. financial markets were well placed to intermediate global savings, and recent dollar strength implied that the demand for U.S. securities was not satiated. ${ }^{9}$ Staff noted that market expectations implied a relative sanguine view of the risks of future dollar weakness (background work, summarized in Annex II.3, finds dollar risk premiums have varied widely over time but have not consistently risen with the increase in net foreign liabilities). Officials responded that, although sharp exchange rate adjustments could not be ruled out, experience suggested that markets could absorb considerable exchange rate movements, particularly since national financial systems had become more resilient.

36. The mission cautioned about the risks of a "disorderly" resolution of imbalances, emphasizing the need for a cooperative global adjustment strategy. This underscored the importance of raising U.S. national saving, including by more ambitious fiscal consolidation, in conjunction with steps toward greater exchange rate flexibility in emerging Asia and continued structural reforms to boost growth in Europe and Japan. Extensive analysis in the World Economic Outlook and elsewhere indicated that a disorderly resolution could significantly lower growth in the United States and abroad (Box 2).$^{10}$ Annex II.4 summarizes background work suggesting that wealth losses to foreign investors from a drop in U.S. asset prices and the value of the dollar could be significant.

37. Officials agreed that the solution to global imbalances would require a multilateral approach. They expressed strong support for the Fund's leadership in the multilateral consultations process, and hoped that this would increase the understanding of the shared

\footnotetext{
${ }^{9}$ Analysis in Chapter 1 of the Selected Issues paper suggests that mortgage securitization has created an asset class that has proved highly attractive to domestic and foreign investors.

${ }^{10}$ Appendix 1.2 of the September 2005 World Economic Outlook simulates the impact on the United States and rest of the world of different scenarios on the resolution of global imbalances.
} 
responsibility for addressing the situation. Officials were concerned that surplus countries had not accepted the need to boost domestic demand relative to output and cautioned that, without such an understanding, efforts to boost U.S. national saving -including through fiscal deficit reduction-would likely have a modest impact on global imbalances but could slow global growth. They also stressed that increased financial globalization argued against pursuing international exchange rate agreements, such as those contained in the 1985 Plaza Accord.

\section{Fiscal Policy: Preparing for an Aging Population}

\section{A. The Long-Term Challenge}

38. Staff and Treasury officials agreed that the long-term fiscal outlook was unsustainable and that entitlement reform was needed (Figure 11). Population aging and rising health care costs are projected to place an ever increasing burden on public retirement and health systems in the United States, as it is in other OECD countries (Figure 12). The FY 2007 budget projects that spending on entitlement programs (including Social Security and Medicare) will rise by around $1 \frac{1}{2}$ percent of GDP each decade through 2080 . With contributions to these programs expected to grow much less rapidly:

- $\quad$ The Trustees currently estimate the 75-year funding gap of the Social Security and Medicare systems at 325 percent of GDP. The Social Security system-which presently runs a cash surplus of $1 \frac{1}{2}$ percent of GDP - is projected to fall into deficit as early as 2017 . The underfunding of the Medicare system is much larger, and has been increased by 80 percent of GDP by the prescription drug benefit.

- Medicaid-the federal and state program providing health coverage for the poor and disabled - also has a large implicit funding gap. The rapid increase in outlays would make it increasingly difficult for states to meet their balanced-budget requirements without spending cuts elsewhere, increased tax revenues, or higher federal transfers.

- $\quad$ Social Security reforms have stalled in Congress. The Administration has proposed establishing a bipartisan commission to examine broad reform of entitlement programs, but there has been little subsequent progress. Greater consensus was needed in Congress to carry the process forward.

\section{B. Medium-Term Budget Policy}

39. Officials emphasized that recent revenue buoyancy and expenditure discipline had improved fiscal prospects (Table 5). Tax receipts through April (which included annual personal tax filings for 2005) exceeded projections on both the personal and corporate side by a significant margin. The reasons for revenue overperformance were still not fully understood, but all indications were that this year's deficit would fall below $2 \frac{1}{2}$ percent of GDP, well under the budget projection of $3 \frac{1}{4}$ percent. As a result, the objective of "halving the deficit" - relative to the $\$ 540$ billion ( $4 \frac{1}{2}$ percent of GDP) that had been forecast for FY2005-now seemed likely to be met by FY 2008, a year ahead of schedule. 


\begin{tabular}{|c|c|c|c|c|c|c|c|c|}
\hline \multicolumn{9}{|c|}{$\begin{array}{l}\text { United States: Budget Projections } \\
\text { (Fiscal years; in percent of GDP) }\end{array}$} \\
\hline & \multirow[b]{2}{*}{2004} & \multirow[b]{2}{*}{2005} & \multicolumn{6}{|c|}{ Projection } \\
\hline & & & 2006 & 2007 & 2008 & 2009 & 2010 & 2011 \\
\hline \multicolumn{9}{|l|}{ FY 2007 Budget } \\
\hline Unified balance & -3.6 & -2.6 & -3.3 & -2.6 & -1.5 & -1.4 & -1.1 & -1.2 \\
\hline Primary balance & -2.2 & -1.1 & -1.6 & -0.8 & 0.3 & 0.5 & 0.8 & 0.7 \\
\hline Unified balance exc. social security & -4.9 & -4.0 & -4.6 & -4.0 & -3.0 & -2.9 & -2.7 & -2.8 \\
\hline Debt held by the public & 37.2 & 37.3 & 38.5 & 39.0 & 38.5 & 37.9 & 37.2 & 36.5 \\
\hline \multicolumn{9}{|l|}{ Staff Projection 1/ } \\
\hline Unified balance & -3.6 & -2.6 & -2.3 & -2.6 & -2.3 & -2.0 & -1.9 & -1.8 \\
\hline Primary balance & -2.2 & -1.1 & -0.6 & -0.8 & -0.5 & -0.2 & -0.1 & 0.0 \\
\hline Unified balance exc. social security & -4.9 & -4.0 & -3.6 & -4.0 & -3.7 & -3.6 & -3.4 & -3.3 \\
\hline Debt held by the public & 37.2 & 37.3 & 37.3 & 38.0 & 38.4 & 38.7 & 38.7 & 38.6 \\
\hline
\end{tabular}

Sources: FY 2007 Budget of the U.S. Government (February 6, 2006); and Fund staff estimates.

1/ Staff projections are based on the Administration's budget adjusted for differences in macroeconomic projections; staff estimates of the cost of ongoing operations in Iraq; some additional non-defense discretionary expenditure; and continued AMT relief beyond FY2007. The projections also assume that PRA's are not introduced.

40. Staff welcomed the improved fiscal performance, which provided the opportunity to embrace a more ambitious medium-term target for deficit reduction. The fall in the federal fiscal deficit largely reflected unexpected revenue buoyancy, whose permanence remained to be seen. The expenditure ratio was still rising despite some recent success in constraining nondefense discretionary spending (comprising about one-fifth of all outlays), reflecting rising costs of entitlement programs and debt service, as well as emergency spending on Afghanistan, Iraq, and hurricane Katrina. Budget projections showing a deficit reduction to 11/4 percent of GDP by FY 2011 appeared unambitious, implying an adjustment of only around 1 percentage point relative to the likely outturn for FY 2006.

41. Balancing the budget excluding the Social Security surplus over the next five years, if coupled with entitlement reform, would restore long-term fiscal sustainability (Box 3 ). Staff analysis suggested that even with reforms that slowed entitlement benefit growth gradually (to provide individuals with time to adjust long-term plans) large additional adjustments would be needed to meet the needs of a growing elderly population. Achieving a balanced budget excluding Social Security would meet this challenge by lowering the debt burden and interest costs, thereby lessening the size of the necessary fiscal adjustment and avoiding placing an undue burden on future generations. This would require annual consolidation of some $3 / 4$ percent of GDP, whose impact on U.S. and global demand seemed manageable.

42. Officials stressed the Administration's commitment to achieving deficit reduction through expenditure restraint. The staff cautioned, however, that the discipline on discretionary spending assumed in the current budget appeared optimistic. Budget proposals involved a backloaded reduction of nondefense discretionary spending as a ratio to GDP to 


\section{Box 3: Attaining Fiscal Sustainability}

Long-term fiscal scenarios illustrate the need to combine entitlement reform with ambitious fiscal consolidation. A baseline scenario developed by the Congressional Budget Office (CBO) illustrates that population aging and rapidly increasing health care costs put federal entitlement spending on an unsustainable path (Scenario A). ${ }^{1}$ It assumes (i) a moderation in annual excess health cost growth - defined as the difference between per capita Medicare and Medicaid costs and inflation-from $2 \frac{1}{2}$ percentage points at present to 1 percentage point after 2030; (ii) a sharp drop in discretionary spending from 10.2 percent of GDP to 7.6 percent in 2030 and 6.6 percent by 2050; and (iii) maintaining the revenue ratio at its long-term average of 18.3 percent of GDP.

Entitlement reform that gradually reduces the growth of health and retirement benefits improves the situation but does not achieve fiscal sustainability (Scenario B). Reforms are assumed to eliminate the annual excess cost growth for Medicare and Medicaid by 2050, which reduces the rise in health care outlays from this source by 40 percent through 2050, and progressive indexation of Social Security benefits is also assumed. ${ }^{2}$ However, these steps are not enough to prevent a rapid build up of debt, reflecting the doubling of the old-age dependency ratio.

Combining such reform with balancing the budget excluding social security by FY 2011 achieves long-term fiscal sustainability. Scenario C augments entitlement reform with medium-term deficit reduction that achieves budget balance, excluding Social Security, in FY 2011 through higher revenues or lower nonentitlement spending. The 3 percent of GDP improvement in the nonentitlement primary balance is assumed to be maintained subsequently.

Alternative paths for achieving fiscal sustainability involve much lower benefits or higher taxes:

- To maintain the revenue ratio at its historical average, excess cost growth in Medicare and Medicaid would need to be eliminated immediately, presumably through benefit reductions, and larger cuts to the nonentitlement spending ratio would be required.

- More gradual deficit reduction - assumed to occur through rescinding the 2001 and 2003 tax cuts and leaving the AMT unreformed - would lead to a higher debt ratio than with the reforms contained in Scenario C, increasing the needed long-term fiscal consolidation by slightly over 2 percentage points of GDP.

\footnotetext{
1 “The Long-Term Budget Outlook,” Congressional Budget Office, December 2005.

2 "Long-Term Analysis of S. 2427, The Sustainable Solvency First for Social Security Act of 2006," Congressional Budget Office, April 2006.
} 
unprecedented lows, relied on several measures that had previously been rejected by Congress, and ignored the costs of funding operations in Iraq and Afghanistan beyond FY 2007 (Chapter 3 of the 2004 Selected Issues paper discusses the potential for expenditure restraint). The team welcomed, therefore, the Administration's support of a reinstatement of pay-as-you-go (PAYGO) rules for mandatory spending and statutory limits on the growth of discretionary spending, but questioned the unwillingness to include tax cuts in the PAYGO rules. $^{11}$

\section{The staff suggested that it would be prudent to explore options for raising the} revenue ratio to meet long-term spending pressures. Given rising entitlement spending, there could be growing pressure to withdraw the 2001-03 marginal income tax cuts due to expire in 2011, and it would be increasingly difficult to bear the revenue costs of reforming the AMT. In order to avoid the attendant negative implications for economic efficiency, a number of options could be considered in the context of a broader tax reform:

- Base broadening. The President's Advisory Panel on Federal Tax Reform offered a number of options for gradually reducing a number of ill-targeted and distortionary tax breaks, including those for mortgage interest payments, employers' contributions to health insurance plan premiums, and state and local tax payments. The team also noted the possibility of raising Social Security and Medicare contribution limits.

- $\quad$ Energy taxation. Energy taxes could yield significant revenues and, by lowering consumption, could also help support of the authorities' energy security and environmental objectives.

- $\quad$ A national $\boldsymbol{V A T}$. An indirect consumption tax would tend to maintain buoyancy even as the workforce retires and, by avoiding taxation of factor incomes, would encourage private saving and investment.

44. Officials responded that it was inadvisable to set a medium-term deficit objective to address spending pressures whose size was uncertain and whose solutions were largely political. The real issue, which would require difficult political choices by Congress rather than shifts in the near-term fiscal stance, was whether U.S. society was prepared to tolerate the higher taxes needed to finance existing entitlement programs or would accept lower entitlement benefits per capita. The Administration opposed revenue increases to finance deficit reduction because of their detrimental supply-side effects. Although the ratio of revenues to GDP would tend to rise gradually over time through bracket creep, they cautioned that in the past the tendency had been to respond with tax cuts, and the ratio had not deviated from its long-term average of slightly over 18 percent of GDP for an extended time in the postwar period.

\footnotetext{
11 The Budget Enforcement Act's PAYGO rules required that any legislation affecting revenues or entitlement programs be deficit neutral, whereas the Administration has proposed exempting tax cuts from this discipline.
} 


\section{Entitlement Reform}

45. The team observed that there appeared to be an urgent need for major reform of the U.S. health care system to contain costs. U.S. health care spending was around 15 percent of GDP, well above the OECD average, with the public sector responsible for around half of the total (Figure 13). Officials agreed on the need for reform and noted that their key focus was on addressing the tendency of third-party insurance to insulate consumers from rising health costs. Accordingly, health savings accounts (HSAs) had been introduced coupled with tax incentives for high deductible health care insurance plans, and steps were also being taken to improve information on the quality and effectiveness of procedures/services.

46. The Administration was encouraging state initiatives to increase the efficiency of the Medicaid program. Officials observed that states were in a better position than the federal government to control health costs through policy initiatives and experimentation. For example, "personal responsibility accounts" that encouraged healthier lifestyles had shown some promise. State representatives agreed that the federal government was providing significant flexibility in the Medicaid program while also tightening the definition of expenses eligible for federal matching grants.

\section{Officials indicated that the Administration was open to a range of reforms of the} Social Security system. The President had endorsed slowing benefit growth by linking payments to a sliding combination of wage and price indexing, which would more than halve the 75-year funding gap. The Administration would consider most additional proposals that moved the system to a sounder financial footing, particularly towards the end of the 75-year funding window, such as indexing benefits to longevity and raising the cap on payroll taxes, although raising payroll tax rates would not be acceptable. While the President had proposed creating Personal Retirement Accounts without raising payroll taxes, other approaches had not been rejected. Staff responded that the key priority was to ensure that reforms are not delayed, as this would only increase the cost of the eventual adjustment.

\section{Trade Policy and OdA}

48. Officials stressed that an ambitious completion of the Doha round remained a priority for the Administration. With trade promotion authority (TPA) expiring mid-2007, there was a need to wrap up negotiations by the end of this year. Staff noted that reductions in U.S. agricultural subsidies, and similar subsidies elsewhere, would need to be a key component of a multilateral deal. Officials responded that the United States had already made an ambitious proposal, including the ultimate elimination of agricultural tariffs and tradedistorting subsidies, and expressed disappointment with the unwillingness of others to reciprocate. They cautioned that it would be impossible to gain Congressional support for lower U.S. agricultural subsidies without a corresponding increase in market access.

49. Officials saw U.S. bilateral free trade arrangements (FTAs) as a complement to multinational negotiations, while staff expressed concern about their proliferation.

U.S. FTAs have been concluded or are under negotiation with 29 countries; only four were in place in 2002. Officials observed that U.S. negotiators sought comprehensive and WTO- 
compatible FTAs that generally increased support within countries for multilateral agreements, and that the United States was looking for free trade "any way it can." Staff responded that the proliferation of preferential agreements could undermine the multilateral fabric of world trade. The potential for defensive responses to others' FTAs suggested there was scope to agree mutual restraints or the inclusion of open-access clauses allowing countries to accede to existing FTAs. Simple and liberal rules of origin were crucial to avoid burdening cross-border value chains.

50. Staff emphasized the importance of resisting mounting protectionist sentiment. In particular, recent Congressional proposals targeted at China risked hurting workers in both countries while having little impact on the U.S. trade balance. Officials responded that they considered United States/Chinese trade relations as healthy and stressed that all U.S. policies were WTO compliant and were aimed at integrating China into the multilateral trading system. Treasury officials observed that the May semiannual report on economic and exchange rate policies had not designated China as a currency manipulator, and indicated that the Administration favored shifting the nomenclature from the inherently subjective concept of "manipulation" to the more analytically precise "misalignment."

51. The mission inquired about prospects for raising the share of U.S. official development assistance $(\mathrm{OD} A)$ in GDP, which remains one of the lowest among industrial countries. While the budget had requested a modest increase for FY 2007, OECD estimates suggested that this could be insufficient to meet the Gleneagles G-8 commitments on increased aid to Africa; the Millennium Challenge Account; and initiatives on HIV/AIDS and malaria. Officials suggested that the United States was well on its way to meeting these commitments, especially with large increases in Millennium Challenge Corporation financing programmed for the next few years. Moreover, they stressed that overall U.S. assistance (including remittances and other private capital flows) remained several times the level of official ODA, and were more important for the United States than for other countries.

\section{StafF APPRAISAL}

52. The U.S. economy has remained a key engine of global growth, despite devastating hurricanes, a withdrawal of monetary stimulus, and high energy prices. Activity has remained robust, supported by strong productivity growth, and buoyant tax revenues seem likely to keep the FY 2006 federal deficit well below initial budget estimates. Looking forward, prospects appear favorable for growth to gradually ease to a more sustainable rate.

53. In the year ahead, the Federal Reserve faces the difficult task of steering a course between competing risks. In particular, a cooling housing market, higher energy prices, and negative household saving rate could weigh more heavily on activity than expected. At the same time, however, the recent pick up in core inflation and expectations, coupled with a further drop in the unemployment rate, have underscored the danger of a build up in price pressures. Given the importance of keeping inflation expectations in check, policymakers have appropriately cautioned that some further policy firming may yet be needed. 
54. There would seem to be merit in the Fed providing a more explicit statement of its inflation objective. While the Fed's communications strategy in recent years has been highly effective, this additional step could help further anchor inflation expectations without undermining confidence in the Fed's commitment to its broader mandate. Providing more frequent Monetary Policy Reports with a greater focus on future developments could also further increase the Fed's high level of transparency.

55. The U.S. financial sector has proven innovative and resilient in recent years. The system appears well-positioned as the credit cycle turns, although conditions in markets for credit derivatives merit close monitoring, and there are important areas where further reform could help enhance the financial system's resilience and efficiency:

- $\quad$ Action is still needed to carry forward the Administration's proposals to strengthen the supervision of the housing GSEs and limit the size of their balance sheets so as to contain systemic risk in financial markets.

- Steps too are needed to improve the funding of the PBGC, strengthen the accounting and transparency of defined benefit pension plans, and improve the incentives for participation in defined contribution plans.

- $\quad$ Supervision and regulation of insurance companies is fragmented and steps to establish a more uniform approach would be welcome.

- $\quad$ Undertaking a Fund FSAP and publishing a regular Financial Stability Report could provide further insights on these challenges.

56. The United States has a major role to play in catalyzing vigorous implementation of the cooperative strategy laid out by the IMFC last April. An orderly resolution of imbalances would be supported by ambitious fiscal consolidation that helps boost national saving. Delaying the inevitable adjustment of global imbalances will mean continued increases in U.S. external indebtedness, heightening the risk of a sharp disruption to exchange rates, financial markets, and growth, both domestically and abroad.

57. The Budget again this year has highlighted that demographic and other pressures threaten both fiscal sustainability and the nation's future prosperity. While there is no doubt that entitlement reform is essential for achieving a sustainable fiscal position, even significant entitlement reforms and cuts in other spending may not be sufficient to accommodate the increased demands on public health and retirement systems from an aging population.

58. With buoyant revenues supporting deficit reduction, the time is opportune to establish a more ambitious medium-term fiscal anchor. In particular, achieving a balanced budget, excluding the Social Security surplus, within the next five years would set the federal debt ratio on a firm downward path, reducing the burden on future generations of providing health care and retirement income to the baby boom generation. It would also provide the needed room to develop and phase in the reforms required to place entitlement systems on a more sustainable basis. Given current budget projections, this would require consolidation of 
around $3 / 4$ percentage point of GDP a year, providing a helpful boost to national saving and multilateral efforts to narrow global imbalances.

59. Although controlling outlays should remain central to deficit reduction, revenue measures should not be ruled out:

- $\quad$ On the expenditure side, despite some success in slowing the growth of discretionary outlays, it may be difficult to sustain expenditure discipline, especially in light of pressures to fund defense commitments and other emergency priorities. Therefore, there would seem merit in re-introducing caps on discretionary outlays, as well as pay-as-you-go (PAYGO) requirements covering both entitlement spending and tax measures.

- $\quad$ On the revenue side, it may be difficult to sustain the significant reductions in marginal tax rates of recent years while meeting the fiscal burden from population aging. Nonetheless, the priority should be on reforms that would broaden the revenue base by reducing tax preferences, including those for mortgage interest payments, employers' contributions to health insurance plan premiums, and state and local tax payments, as suggested by the President's Advisory Panel. Consideration could also be given to consumption-based indirect taxes - such as a national sales tax, a VAT, or energy taxation - that would maintain revenue buoyancy as workers retire.

60. It is critically important to re-invigorate the momentum for entitlement reform. The Administration has offered some useful suggestions - including for "progressive price indexation"- and the challenge for policymakers is to form the necessary consensus to develop a package of reforms that can place the Social Security system on a sustainable basis. However, especially with the addition of the new prescription drug benefit, the financial shortfall of the Medicare system dwarfs that of Social Security, and while highdeductible health plans and other measures may help improve incentives, a broader, fundamental reform of the U.S. health care system seems necessary.

\section{Leadership by the United States remains key to global trade liberalization.}

Continued U.S. commitment and initiative is needed to ensure sufficient momentum for an ambitious conclusion to the Doha Round negotiations. At the same time, care will be needed to resist domestic protectionist sentiment and to ensure that bilateral trade initiatives complement rather than substitute multilateral approaches. Further boosting ODA would help achieve the ambitious goals already agreed to support the poorest countries in the world.

62. It is expected that the next Article IV consultation with the United States will be held on the regular 12-month cycle. 
Table 1. Selected Economic Indicators

(Percentage change from previous period at annual rate, unless otherwise indicated)

\begin{tabular}{|c|c|c|c|c|c|c|c|c|c|c|c|c|c|}
\hline & 2005 & 2006 & 2007 & 2008 & 2009 & 2010 & 2011 & $\begin{array}{c}2005 \\
\text { Q3 }\end{array}$ & Q4 & $\begin{array}{c}2006 \\
\text { Q1 }\end{array}$ & Q2 & Q3 & Q4 \\
\hline \multicolumn{14}{|l|}{ National production and income } \\
\hline Real GDP & 3.5 & 3.5 & 3.1 & 3.2 & 3.2 & 3.2 & 3.2 & 4.1 & 1.7 & 5.6 & 2.8 & 2.9 & 3.1 \\
\hline Net Exports 1/ & -0.3 & -0.4 & -0.2 & -0.1 & -0.1 & -0.1 & -0.1 & -0.1 & -1.4 & -0.2 & -0.4 & -0.3 & -0.3 \\
\hline Total domestic demand & 3.6 & 3.7 & 3.1 & 3.1 & 3.1 & 3.1 & 3.1 & 4.0 & 2.9 & 5.5 & 3.0 & 3.0 & 3.2 \\
\hline Final domestic demand & 3.9 & 3.6 & 3.1 & 3.1 & 3.1 & 3.1 & 3.1 & 4.5 & 1.1 & 5.8 & 3.0 & 3.1 & 3.1 \\
\hline Private final consumption & 3.5 & 3.1 & 2.8 & 2.8 & 2.8 & 2.9 & 2.9 & 4.1 & 0.9 & 5.0 & 2.5 & 2.6 & 2.8 \\
\hline Public consumption expenditure & 1.5 & 2.6 & 3.1 & 2.1 & 2.0 & 2.2 & 2.1 & 4.0 & -1.7 & 4.7 & 3.4 & 3.3 & 3.3 \\
\hline Gross fixed domestic investment & 7.2 & 6.1 & 4.4 & 4.9 & 4.9 & 4.7 & 4.6 & 6.3 & 3.8 & 9.3 & 4.7 & 4.3 & 4.0 \\
\hline Private fixed investment & 8.1 & 6.5 & 4.6 & 5.4 & 5.3 & 5.1 & 5.1 & 8.0 & 3.9 & 10.1 & 4.9 & 4.4 & 4.0 \\
\hline Equipment \& software & 10.9 & 9.8 & 8.1 & 8.0 & 8.0 & 8.0 & 8.0 & 10.6 & 5.0 & 14.8 & 9.0 & 8.0 & 8.0 \\
\hline Structures (non-residential) & 2.0 & 6.0 & 4.8 & 3.6 & 3.5 & 3.2 & 3.0 & 2.2 & 3.0 & 12.6 & 4.0 & 6.0 & 6.0 \\
\hline Structures (residential) & 7.1 & 2.6 & -0.2 & 2.8 & 2.4 & 2.0 & 2.0 & 7.3 & 2.8 & 3.3 & 0.0 & -1.0 & -2.0 \\
\hline Public fixed investment & 3.0 & 3.8 & 3.4 & 2.2 & 2.8 & 2.5 & 2.1 & -2.4 & 3.4 & 5.0 & 3.6 & 3.6 & 3.5 \\
\hline Change in private inventories $1 /$ & -0.3 & 0.1 & 0.0 & 0.0 & 0.0 & 0.0 & 0.0 & -0.4 & 1.9 & -0.2 & 0.0 & 0.0 & 0.1 \\
\hline Nominal GDP & 6.4 & 6.4 & 5.2 & 5.3 & 5.3 & 5.3 & 5.3 & 7.6 & 5.2 & 8.9 & 5.1 & 5.1 & 5.2 \\
\hline Personal saving ratio $(\%$ of DI) & -0.5 & -0.6 & 0.3 & 1.1 & 1.7 & 2.3 & 2.9 & -1.6 & -0.5 & -1.4 & -0.8 & -0.3 & 0.0 \\
\hline Private investment rate ( $\%$ of GDP) & 16.9 & 17.5 & 17.6 & 17.9 & 18.2 & 18.4 & 18.6 & 16.7 & 17.3 & 17.4 & 17.5 & 17.5 & 17.5 \\
\hline \multicolumn{14}{|l|}{ Employment and inflation } \\
\hline Output gap & -0.4 & -0.1 & -0.2 & -0.2 & -0.2 & -0.1 & 0.0 & -0.2 & -0.6 & 0.0 & -0.1 & -0.2 & -0.2 \\
\hline Potential GDP & 3.3 & 3.3 & 3.2 & 3.2 & 3.2 & 3.1 & 3.1 & 3.3 & 3.3 & 3.3 & 3.3 & 3.2 & 3.2 \\
\hline Unemployment rate (percent) & 5.1 & 4.8 & 4.8 & 4.8 & 4.8 & 4.8 & 4.8 & 5.0 & 4.9 & 4.7 & 4.8 & 4.8 & 4.8 \\
\hline CPI inflation & 3.4 & 3.2 & 2.6 & 2.5 & 2.5 & 2.5 & 2.5 & 5.5 & 3.2 & 2.2 & 3.1 & 2.7 & 2.5 \\
\hline GDP deflator & 2.8 & 2.8 & 2.0 & 2.0 & 2.0 & 2.0 & 2.0 & 3.3 & 3.5 & 3.1 & 2.2 & 2.1 & 2.0 \\
\hline \multicolumn{14}{|l|}{ Financial policy indicators } \\
\hline Central gov't balance ( $\$$ b, public accounts) & -318 & -296 & -354 & -329 & -314 & -308 & -304 & & & & & & \\
\hline In percent of FY GDP & -2.6 & -2.3 & -2.6 & -2.3 & -2.0 & -1.9 & -1.8 & $\ldots$ & $\cdots$ & ... & $\cdots$ & $\cdots$ & $\ldots$ \\
\hline Central government balance ( $\$$ b, NIPA) & -380 & -367 & -424 & -405 & -386 & -377 & -341 & & & & & & \\
\hline In percent of CY GDP & -3.0 & -2.8 & -3.0 & -2.7 & -2.5 & -2.3 & -2.0 & $\cdots$ & $\cdots$ & $\cdots$ & $\cdots$ & $\cdots$ & ... \\
\hline General government balance ( $\$ b$, NIPA) & -478 & -442 & -478 & -452 & -454 & -441 & -402 & & & & & & \\
\hline In percent of CY GDP & -3.8 & -3.3 & -3.4 & -3.1 & -2.9 & -2.7 & -2.3 & $\ldots$ & $\ldots$ & $\ldots$ & $\ldots$ & $\ldots$ & $\ldots$ \\
\hline Three-month Treasury bill rate & 3.2 & 5.0 & 5.3 & 5.3 & 5.3 & 5.3 & 5.3 & 3.4 & 3.9 & 4.5 & 4.9 & 5.2 & 5.3 \\
\hline Ten-year government bond rate & 4.3 & 5.2 & 5.8 & 6.0 & 6.0 & 6.0 & 6.0 & 4.2 & 4.5 & 4.6 & 5.1 & 5.4 & 5.6 \\
\hline \multicolumn{14}{|l|}{ Balance of payments } \\
\hline Current account balance $(\$ \mathrm{~b})$ & -792 & -868 & -935 & -984 & -1035 & -1089 & -1145 & -734 & -892 & -835 & -868 & -884 & -886 \\
\hline Merchandise trade balance $(\$ b)$ & -783 & -875 & -912 & -933 & -951 & -972 & -997 & -795 & -850 & -832 & -877 & -893 & -900 \\
\hline Balance on invisibles $(\$$ b) & -9 & 7 & -23 & -52 & -84 & -116 & -148 & 61 & -42 & -3 & 9 & 9 & 14 \\
\hline Current account balance ( $\%$ of GDP) & -6.3 & -6.5 & -6.7 & -6.7 & -6.7 & -6.7 & -6.7 & -5.8 & -7.0 & -6.4 & -6.6 & -6.6 & -6.5 \\
\hline Merchandise trade balance ( $\%$ of GDP) & -6.3 & -6.6 & -6.5 & -6.3 & -6.1 & -6.0 & -5.8 & -6.3 & -6.7 & -6.4 & -6.6 & -6.7 & -6.6 \\
\hline Balance on invisibles ( $\%$ of GDP) & -0.1 & 0.1 & -0.2 & -0.4 & -0.5 & -0.7 & -0.9 & 0.5 & -0.3 & 0.0 & 0.1 & 0.1 & 0.1 \\
\hline Export volume 2/ & 7.3 & 11.1 & 9.8 & 8.8 & 8.7 & 9.0 & 9.0 & 3.2 & 8.0 & 18.5 & 8.6 & 11.1 & 10.6 \\
\hline Import volume $2 /$ & 6.9 & 8.8 & 7.3 & 6.1 & 5.8 & 6.2 & 6.3 & 3.5 & 13.5 & 11.1 & 8.3 & 8.6 & 8.3 \\
\hline \multicolumn{14}{|l|}{ Saving and investment (as a share of GDP) } \\
\hline Gross national saving & 13.4 & 14.2 & 14.2 & 14.5 & 14.7 & 14.9 & 15.1 & 13.6 & 13.2 & 14.1 & 14.1 & 14.1 & 14.3 \\
\hline General government & -0.6 & -0.1 & -0.2 & 0.1 & 0.3 & 0.5 & 0.9 & -1.2 & -0.5 & 0.3 & -0.3 & -0.2 & -0.2 \\
\hline Private & 14.0 & 14.2 & 14.4 & 14.4 & 14.4 & 14.4 & 14.3 & 14.9 & 13.7 & 13.8 & 14.5 & 14.3 & 14.4 \\
\hline Personal & -0.3 & -0.4 & 0.2 & 0.8 & 1.3 & 1.7 & 2.2 & -1.1 & -0.4 & -1.0 & -0.6 & -0.2 & 0.0 \\
\hline Business & 14.3 & 14.7 & 14.2 & 13.5 & 13.2 & 12.7 & 12.1 & 16.0 & 14.1 & 14.8 & 15.0 & 14.5 & 14.4 \\
\hline Gross domestic investment & 20.1 & 20.7 & 20.9 & 21.2 & 21.4 & 21.6 & 21.8 & 19.9 & 20.5 & 20.7 & 20.7 & 20.7 & 20.8 \\
\hline
\end{tabular}

Sources: Haver Analytics; and Fund staff estimates.

$1 /$ Contributions to growth.

2/ NIPA basis, goods. 
Table 2. Economic Performance of Major Industrial Countries

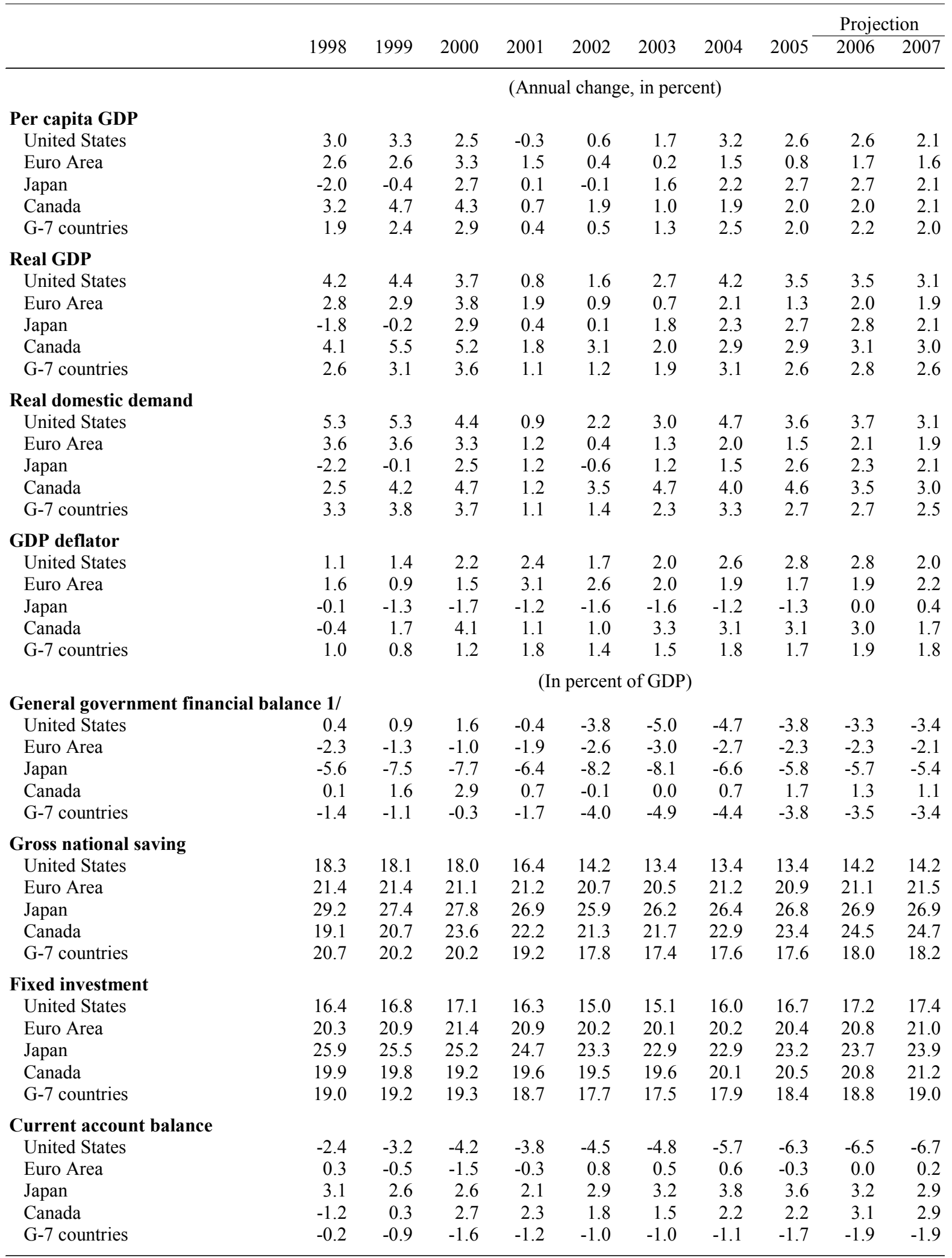

Sources: IMF, World Economic Outlook; and Fund staff estimates.

1 / National accounts basis. 
Table 3. Balance of Payments

(Billions of U.S. dollars, unless otherwise indicated)

\begin{tabular}{|c|c|c|c|c|c|c|c|}
\hline & 1999 & 2000 & 2001 & 2002 & 2003 & 2004 & 2005 \\
\hline Current account & -300 & -415 & -389 & -472 & -528 & -665 & -792 \\
\hline Percent of GDP & -3.2 & -4.2 & -3.8 & -4.5 & -4.8 & -5.7 & -6.3 \\
\hline Goods and services & -263 & -378 & -363 & -421 & -495 & -611 & -717 \\
\hline Merchandise trade & -346 & -452 & -427 & -482 & -547 & -665 & -783 \\
\hline Exports & 684 & 772 & 719 & 682 & 713 & 808 & 895 \\
\hline Imports & $-1,030$ & $-1,224$ & $-1,146$ & $-1,165$ & $-1,261$ & $-1,473$ & $-1,677$ \\
\hline Services & 83 & 75 & 64 & 61 & 52 & 54 & 66 \\
\hline Receipts & 282 & 299 & 286 & 292 & 303 & 344 & 381 \\
\hline Payments & -199 & -224 & -222 & -231 & -250 & -290 & -315 \\
\hline Income & 14 & 21 & 25 & 12 & 37 & 28 & 11 \\
\hline Receipts & 294 & 351 & 288 & 271 & 303 & 375 & 475 \\
\hline Payments & -280 & -330 & -263 & -258 & -266 & -347 & -463 \\
\hline Unilateral transfers & -50 & -59 & -51 & -64 & -69 & -82 & -86 \\
\hline Government transfers & -14 & -17 & -12 & -17 & -22 & -23 & -31 \\
\hline Private transfers & -37 & -42 & -40 & -46 & -47 & -58 & -55 \\
\hline $\begin{array}{l}\text { Capital account } \\
\text { transactions, net }\end{array}$ & -5 & -1 & -1 & -1 & -3 & -2 & -4 \\
\hline Financial account & 236 & 486 & 400 & 503 & 538 & 582 & 785 \\
\hline Private capital & 181 & 445 & 378 & 391 & 258 & 190 & 566 \\
\hline Direct investment & 65 & 162 & 25 & -70 & -86 & -111 & 101 \\
\hline Outflows & -225 & -159 & -142 & -154 & -150 & -244 & -9 \\
\hline Inflows & 289 & 321 & 167 & 84 & 64 & 133 & 110 \\
\hline Securities & 155 & 267 & 313 & 357 & 182 & 353 & 513 \\
\hline Outflows & -122 & -128 & -91 & -49 & -147 & -147 & -180 \\
\hline Inflows & 277 & 395 & 403 & 405 & 329 & 499 & 693 \\
\hline Net U.S. bank flows & -16 & -16 & -17 & 58 & 84 & -25 & -33 \\
\hline Nonbank capital flows & -21 & 32 & 58 & 46 & 78 & -27 & -14 \\
\hline U.S. official reserves & 9 & 0 & -5 & -4 & 2 & 3 & 14 \\
\hline Foreign official assets & 44 & 43 & 28 & 116 & 278 & 388 & 199 \\
\hline Other items & 3 & -1 & 0 & 0 & 1 & 2 & 6 \\
\hline Statistical discrepancy & 69 & -70 & -10 & -29 & -8 & 85 & 10 \\
\hline
\end{tabular}

Source: Haver Analytics. 
Table 4. Indicators of External and Financial Vulnerability

(In percent of GDP, unless otherwise indicated)

\begin{tabular}{|c|c|c|c|c|c|c|c|c|}
\hline & 1998 & 1999 & 2000 & 2001 & 2002 & 2003 & 2004 & 2005 \\
\hline \multicolumn{9}{|l|}{ External indicators } \\
\hline Exports of goods and services (percent change) & -0.1 & 3.5 & 10.8 & -6.1 & -3.0 & 4.2 & 13.4 & 10.7 \\
\hline Imports of goods and services (percent change) & 5.3 & 12.0 & 17.8 & -5.6 & 2.1 & 8.3 & 16.7 & 13.0 \\
\hline Terms of trade (percent change) & 2.9 & -2.1 & -4.6 & 2.8 & 1.5 & -1.3 & -1.7 & -4.0 \\
\hline Current account balance & -2.4 & -3.2 & -4.2 & -3.8 & -4.5 & -4.8 & -5.7 & -6.3 \\
\hline Capital and financial account balance & 0.8 & 2.5 & 4.9 & 3.9 & 4.8 & 4.9 & 4.9 & 6.3 \\
\hline \multicolumn{9}{|l|}{ Of which: } \\
\hline Net portfolio investment & 0.5 & 2.3 & 3.1 & 3.3 & 4.5 & 4.2 & 6.3 & 5.9 \\
\hline Net foreign direct investment & 0.4 & 0.7 & 1.7 & 0.2 & -0.7 & -0.8 & -0.9 & 0.8 \\
\hline Net other investment & -0.1 & -0.4 & 0.2 & 0.4 & 1.0 & 1.5 & -0.4 & -0.4 \\
\hline Official reserves (billion dollars) & 81.8 & 71.5 & 67.6 & 68.7 & 79.0 & 85.9 & 86.8 & 65.1 \\
\hline Central bank foreign liabilities (billion dollars) & 0.2 & 0.1 & 0.3 & 0.1 & 0.1 & 0.2 & 0.1 & 0.1 \\
\hline Official reserves (months of imports) & 0.9 & 0.7 & 0.6 & 0.6 & 0.7 & 0.7 & 0.6 & 0.4 \\
\hline Net international investment position $1 /$ & -12.2 & -11.2 & -16.1 & -23.1 & -23.4 & -21.6 & -21.7 & $\ldots$ \\
\hline Of which: General government debt 2/ & 13.9 & 12.2 & 11.6 & 12.1 & 13.8 & 15.8 & 18.2 & $\ldots$ \\
\hline External debt-to-exports ratio & 1.0 & 0.8 & 1.3 & 1.9 & 2.2 & 2.1 & 2.2 & $\ldots$ \\
\hline External interest payments to exports (percent) $3 /$ & 22.7 & 22.6 & 24.8 & 24.1 & 21.2 & 18.1 & 20.5 & 26.4 \\
\hline Nominal effective exchange rate (percent change) & 9.1 & -0.3 & 2.6 & 5.2 & 0.0 & -6.4 & -4.9 & -2.7 \\
\hline Real effective exchange rate (percent change) & 7.1 & -1.0 & 3.3 & 5.6 & -0.2 & -6.4 & -4.6 & -1.5 \\
\hline \multicolumn{9}{|l|}{ Financial market indicators } \\
\hline General government gross debt & 66.2 & 62.8 & 57.1 & 56.6 & 58.9 & 61.8 & 62.5 & 62.9 \\
\hline Three-month Treasury bill yield (percent) & 4.9 & 4.8 & 6.0 & 3.5 & 1.6 & 1.0 & 1.4 & 3.2 \\
\hline Three-month Treasury bill yield (percent, real) & 3.3 & 2.5 & 2.5 & 0.6 & 0.0 & -1.2 & -1.2 & -0.2 \\
\hline \multicolumn{9}{|l|}{ Equity market index } \\
\hline (percent change in S\&P500, year average) & 24.2 & 22.3 & 7.6 & -16.4 & -16.5 & -3.2 & 17.3 & 6.8 \\
\hline \multicolumn{9}{|c|}{ Banking sector risk indicators (percent unless otherwise indicated) 4/ } \\
\hline Total assets (in billions of dollars) & 5,443 & 5,735 & 6,246 & 6,552 & 7,077 & 7,601 & 8,414 & 9,040 \\
\hline Total loans and leases to assets & 59.5 & 60.8 & 61.1 & 59.3 & 58.7 & 58.3 & 58.3 & 59.5 \\
\hline Total loans to deposits & 87.9 & 91.1 & 91.3 & 88.7 & 88.6 & 88.0 & 87.7 & 88.6 \\
\hline Problem loans to total loans and leases 5/ & 1.0 & 1.0 & 1.1 & 1.4 & 1.5 & 1.2 & 0.9 & 0.8 \\
\hline Nonperforming assets to assets & 0.7 & 0.6 & 0.7 & 0.9 & 0.9 & 0.8 & 0.6 & 0.5 \\
\hline \multicolumn{9}{|l|}{ Loss allowance to: } \\
\hline Total loans and leases & 1.8 & 1.7 & 1.7 & 1.9 & 1.9 & 1.7 & 1.5 & 1.3 \\
\hline Noncurrent loans and leases & 183.2 & 178.0 & 149.4 & 132.4 & 127.2 & 145.7 & 174.7 & 170.5 \\
\hline Return on equity & 13.9 & 15.3 & 14.0 & 13.1 & 14.5 & 15.3 & 13.7 & 12.9 \\
\hline Return on assets & 1.2 & 1.3 & 1.2 & 1.2 & 1.3 & 1.4 & 1.3 & 1.3 \\
\hline Total capital to risk-weighted assets & 12.2 & 12.2 & 12.1 & 12.7 & 12.8 & 12.8 & 12.6 & 12.3 \\
\hline Core capital ratio & 7.5 & 7.8 & 7.7 & 7.8 & 7.8 & 7.9 & 7.8 & 7.9 \\
\hline
\end{tabular}

Sources: IMF, International Financial Statistics; Federal Deposit Insurance Corporation; and Haver Analytics. $1 /$ With FDI at market value.

2/ Excludes foreign private holdings of U.S. government securities other than Treasuries.

3/ External interest payments: income payments on foreign-owned assets (other private payments plus

U.S. government payments).

4/ FDIC-insured commercial banks.

5/ Noncurrent loans and leases. 
Table 5. Fiscal Indicators

(Fiscal years; in percent of GDP except where otherwise indicated)

\begin{tabular}{llllllll} 
& & \multicolumn{6}{c}{ Projection } \\
\cline { 2 - 7 } 2004 & 2005 & 2006 & 2007 & 2008 & 2009 & 2010 & 2011
\end{tabular}

\section{FY 2007 Budget, Administration}

Outlays
Debt service
Other
Revenue
Unified balance
Primary balance
Unified balance exc. social security
Unified balance (billion dollars)
Debt held by the public

$\begin{array}{rrrrrrrr}19.9 & 20.1 & 20.8 & 20.1 & 19.4 & 19.1 & 19.0 & 19.1 \\ 1.4 & 1.5 & 1.7 & 1.8 & 1.9 & 1.9 & 1.9 & 1.9 \\ 18.5 & 18.6 & 19.1 & 18.3 & 17.5 & 17.2 & 17.1 & 17.2 \\ 16.3 & 17.5 & 17.5 & 17.6 & 17.8 & 17.7 & 17.9 & 17.9 \\ -3.6 & -2.6 & -3.3 & -2.6 & -1.5 & -1.4 & -1.1 & -1.2 \\ -2.2 & -1.1 & -1.6 & -0.8 & 0.3 & 0.5 & 0.8 & 0.7 \\ -4.9 & -4.0 & -4.6 & -4.0 & -3.0 & -2.9 & -2.7 & -2.8 \\ -412.0 & -318.0 & -424.0 & -354.0 & -224.0 & -208.0 & -183.0 & -205.0 \\ 37.2 & 37.3 & 38.5 & 39.0 & 38.5 & 37.9 & 37.2 & 36.5\end{array}$

FY 2007 Budget, Adjusted for Staff's Budget and Economic Assumptions 1/

\begin{tabular}{|c|c|c|c|c|c|c|c|c|}
\hline Outlays & 19.9 & 20.1 & 20.2 & 20.6 & 20.4 & 20.1 & 20.0 & 20.0 \\
\hline Debt service & 1.4 & 1.5 & 1.6 & 1.7 & 1.8 & 1.9 & 1.8 & 1.8 \\
\hline Other & 18.5 & 18.6 & 18.6 & 18.9 & 18.6 & 18.3 & 18.3 & 18.3 \\
\hline Revenue & 16.3 & 17.5 & 18.0 & 18.1 & 18.1 & 18.1 & 18.1 & 18.3 \\
\hline Unified balance & -3.6 & -2.6 & -2.3 & -2.6 & -2.3 & -2.0 & -1.9 & -1.8 \\
\hline Primary balance & -2.2 & -1.1 & -0.6 & -0.8 & -0.5 & -0.2 & -0.1 & 0.0 \\
\hline Unified balance exc. social security & -4.9 & -4.0 & -3.6 & -4.0 & -3.7 & -3.6 & -3.4 & -3.3 \\
\hline Unified balance (billion dollars) & -412.0 & -318.0 & -296.0 & -353.6 & -329.2 & -313.7 & -307.5 & -303.9 \\
\hline Debt held by the public & 37.2 & 37.3 & 37.3 & 38.0 & 38.4 & 38.7 & 38.7 & 38.6 \\
\hline \multicolumn{9}{|l|}{ Memorandum items: } \\
\hline Structural unified balance 2/ & -3.4 & -2.5 & -2.2 & -2.5 & -2.2 & -2.0 & -1.9 & -1.8 \\
\hline Primary structural unified balance & -2.0 & -1.0 & -0.6 & -0.8 & -0.5 & -0.1 & -0.1 & 0.0 \\
\hline \multicolumn{9}{|c|}{ Administration's economic projections (in percent, calendar-year basis) } \\
\hline Real GDP growth & 4.2 & 3.5 & 3.4 & 3.3 & 3.3 & 3.1 & 3.1 & 3.1 \\
\hline CPI inflation & 2.7 & 3.4 & 3.0 & 2.4 & 2.4 & 2.4 & 2.4 & 2.5 \\
\hline Three-month Treasury bill rate & 1.4 & 3.2 & 4.2 & 4.2 & 4.3 & 4.3 & 4.3 & 4.3 \\
\hline Central government balance (calendar-year basis) 3/ & -3.5 & -2.7 & -2.4 & -2.7 & -2.4 & -2.1 & -2.0 & -1.7 \\
\hline General government balance (calendar-year basis) 3/ & -4.7 & -4.0 & -3.5 & -3.6 & -3.3 & -3.1 & -2.9 & -2.5 \\
\hline
\end{tabular}

Sources: FY 2007 Budget of the U.S. Government (February 6, 2006); and Fund staff estimates.

1/ Staff projections are based on the Administration's budget adjusted for differences in macroeconomic projections; staff estimates of the cost of ongoing operations in Iraq; some additional non-defense discretionary expenditure; and continued AMT relief beyond FY2007. The projections also assume that PRA's are not introduced.

2/ As a percent of potential GDP, based on proposed measures, under IMF staff's economic assumptions.

3/ On a national accounts basis. The projections use Fund staff budget and economic assumptions. 
Figure 1. Economic Activity: Recent Developments and Outlook
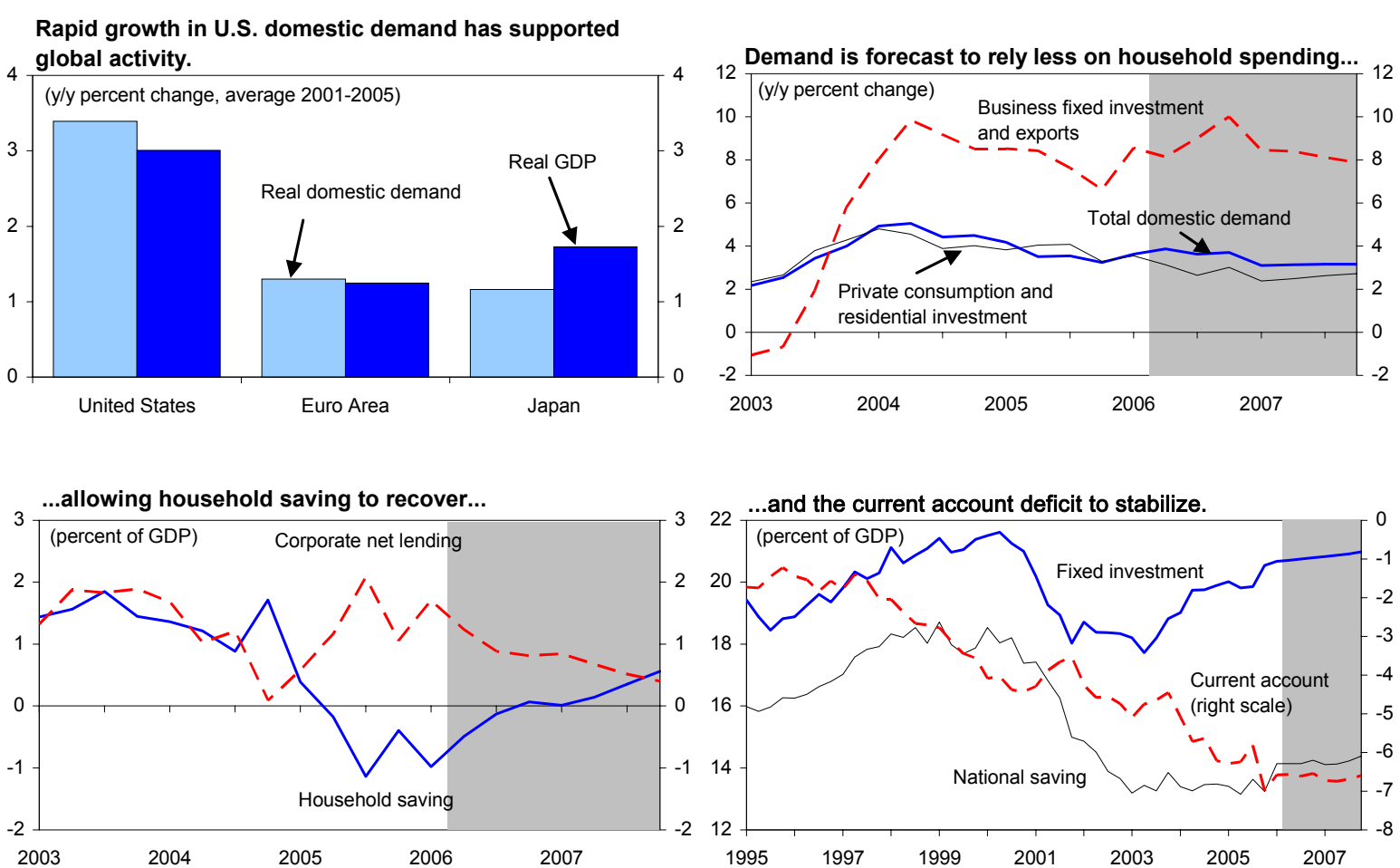

Risks to activity are on the downside...

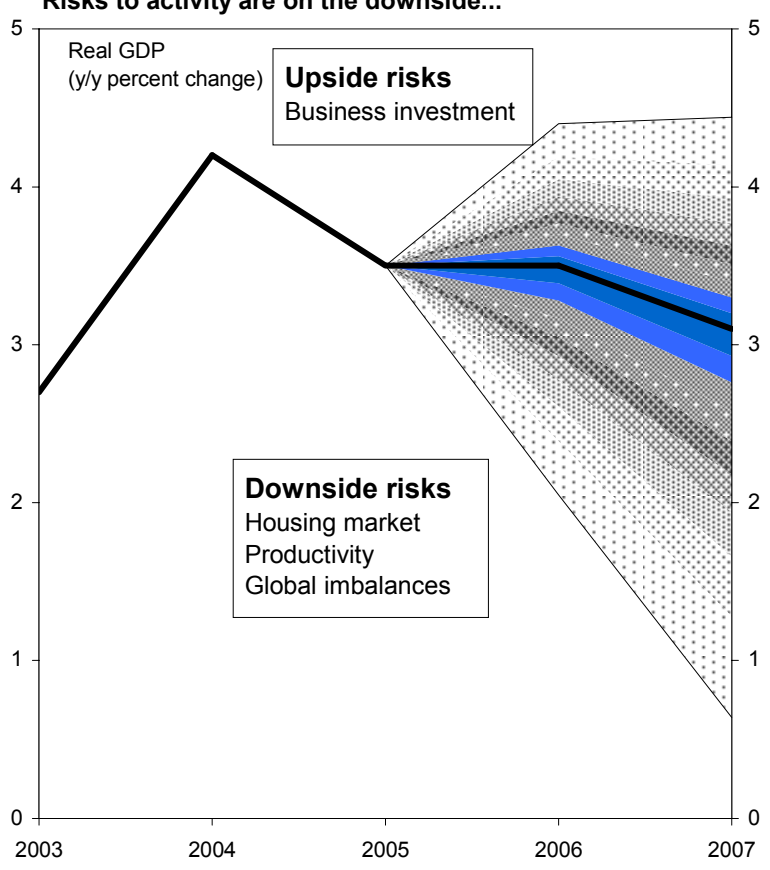

...while those to inflation are biased upward.

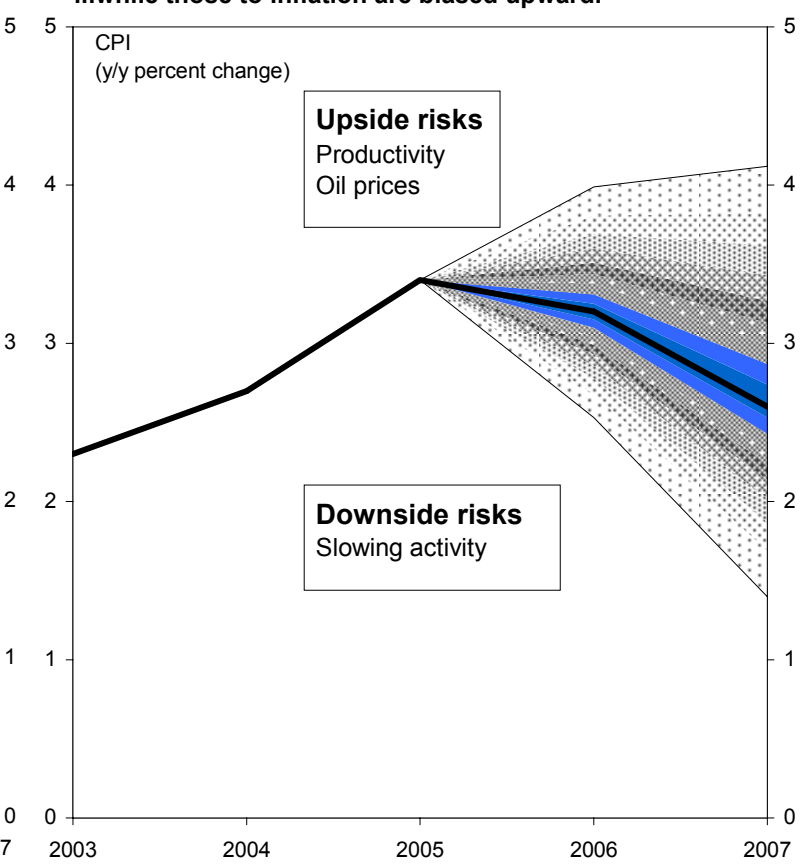

Sources: Haver Analytics; International Monetary Fund, World Economic Outlook; and Fund staff estimates. 
Figure 2. Household Activity and Balance Sheets

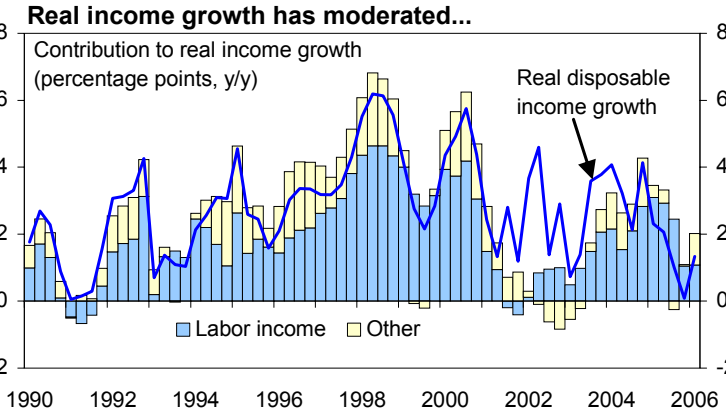

The saving rate has turned negative as wealth has recovered from post-bubble losses.

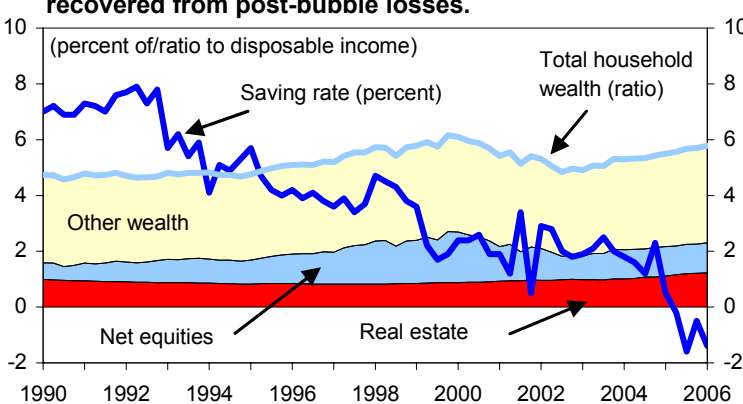

...mirroring developments in countries with similar financial systems.

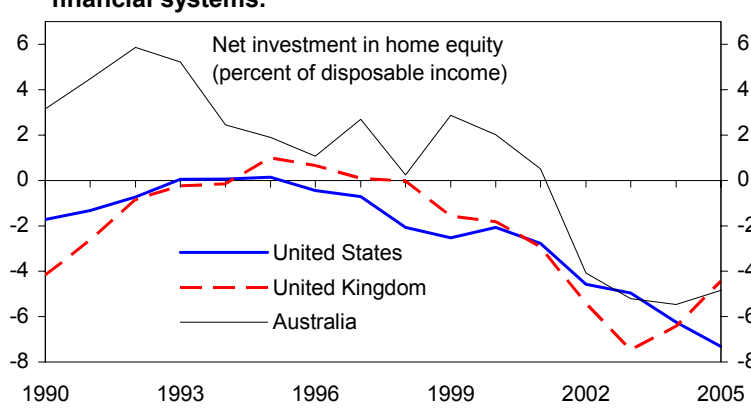

...but the increase in financial obligations has remained moderate...

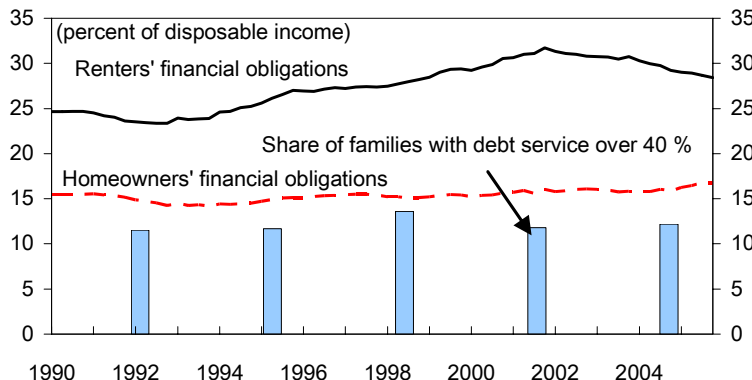

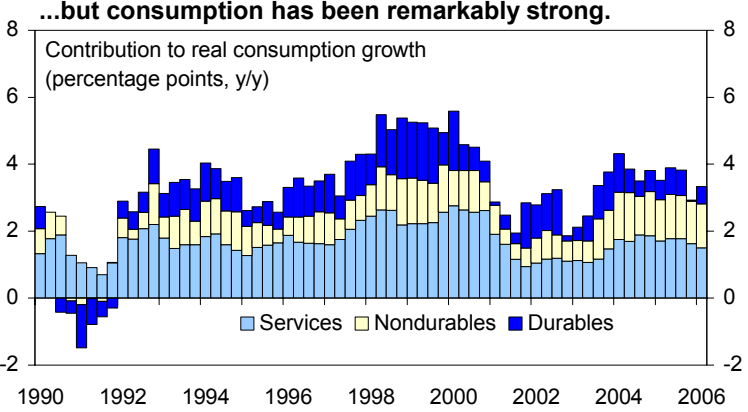

Home equity withdrawal has risen to record levels,

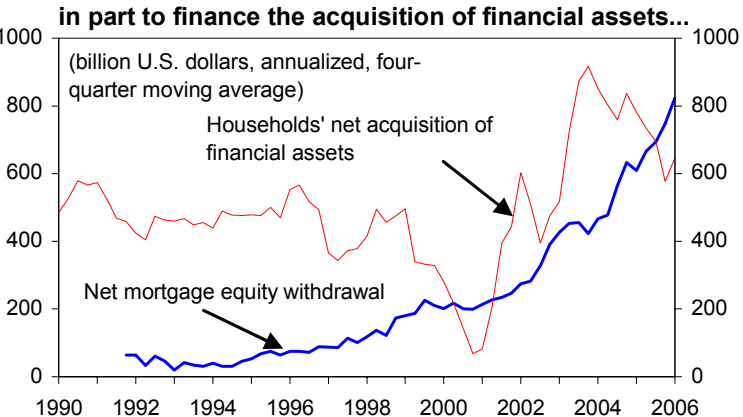

Mortgage debt has risen sharply...

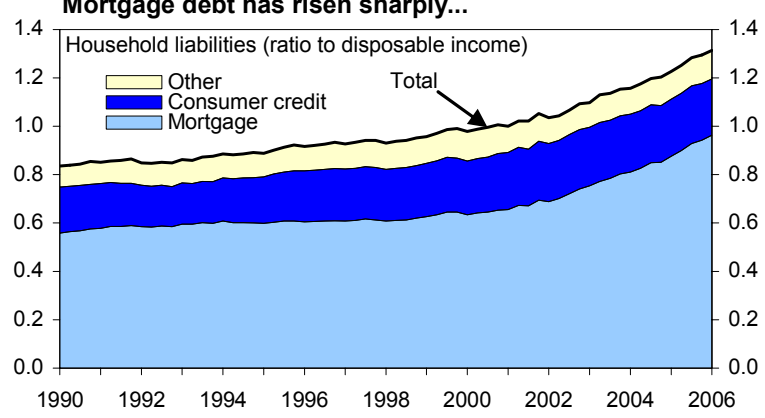

....and credit quality indicators remain within their historical range.

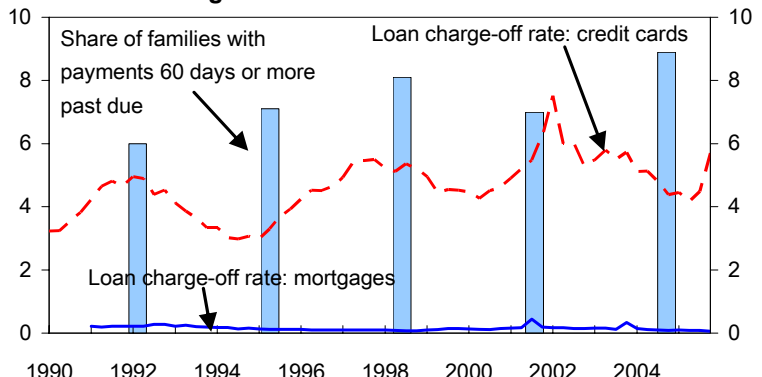

Sources: Federal Reserve Board, Survey of Consumer Finances; Haver Analytics; Australian Bureau of Statistics; Bank of England; and Fund staff calculations. 
Figure 3. Housing Market Indicators
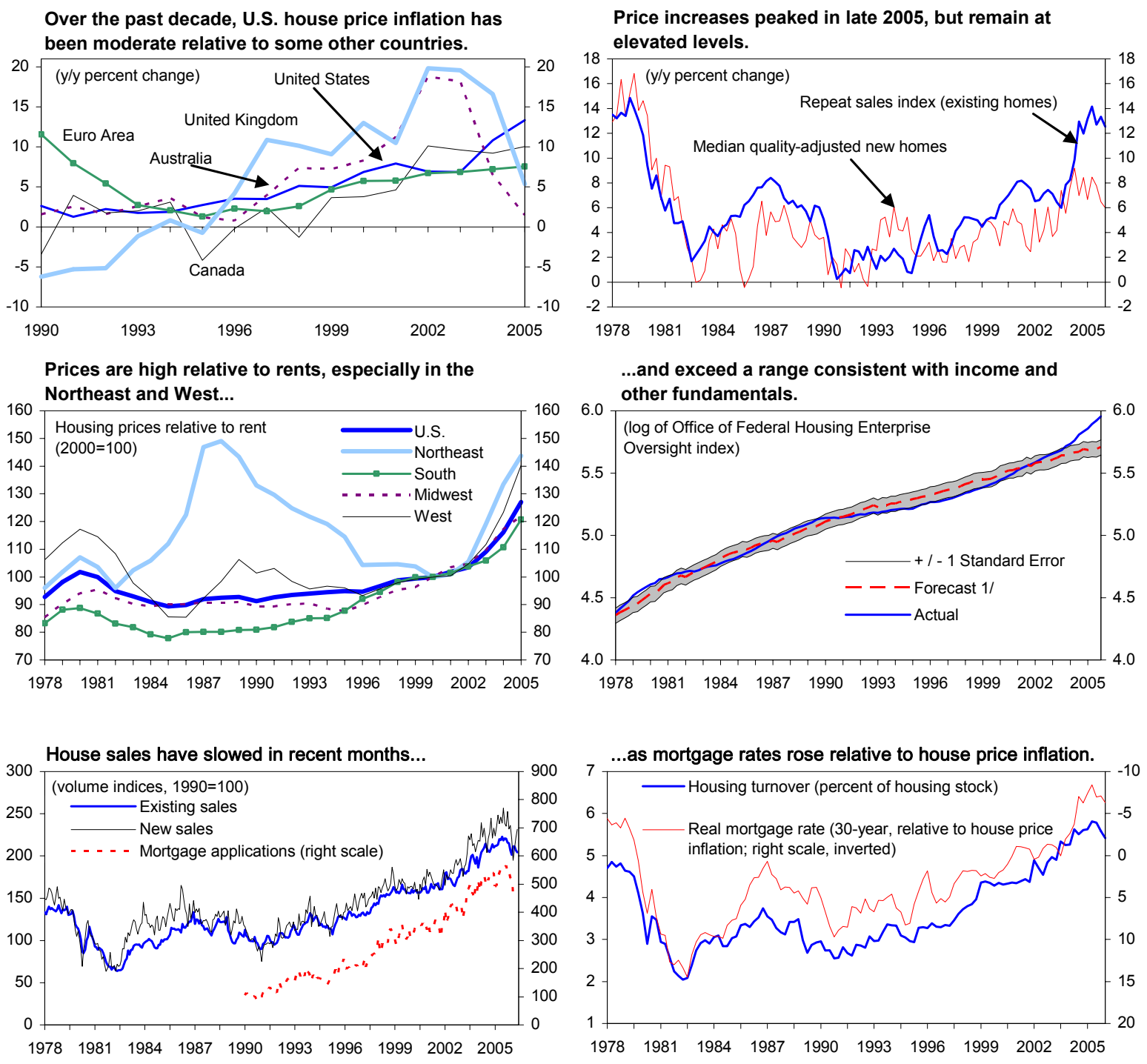

Housing inventories remain at moderate levels...

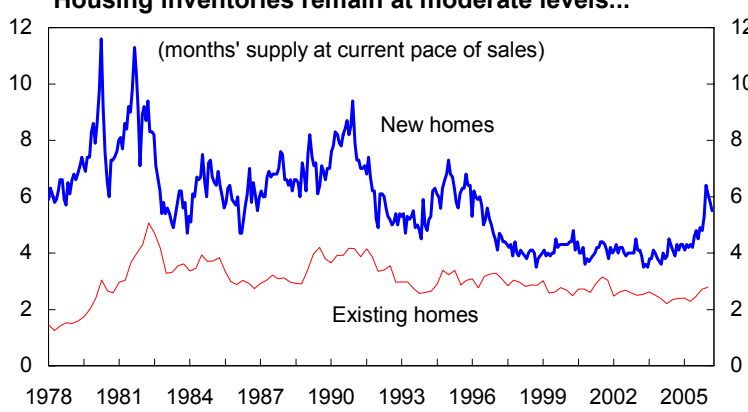

...but residential investment may weaken if house price inflation declines.

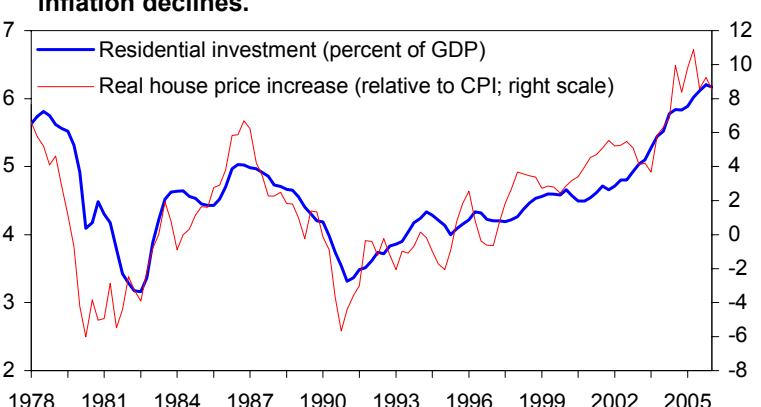

Sources: Haver Analytics; National Sources; and Fund staff calculations.

1/ See Chapter 2 of United States: Selected Issues (IMF Country Report 03/245) for a description of the methodology. 
Figure 4. Corporate Sector Indicators
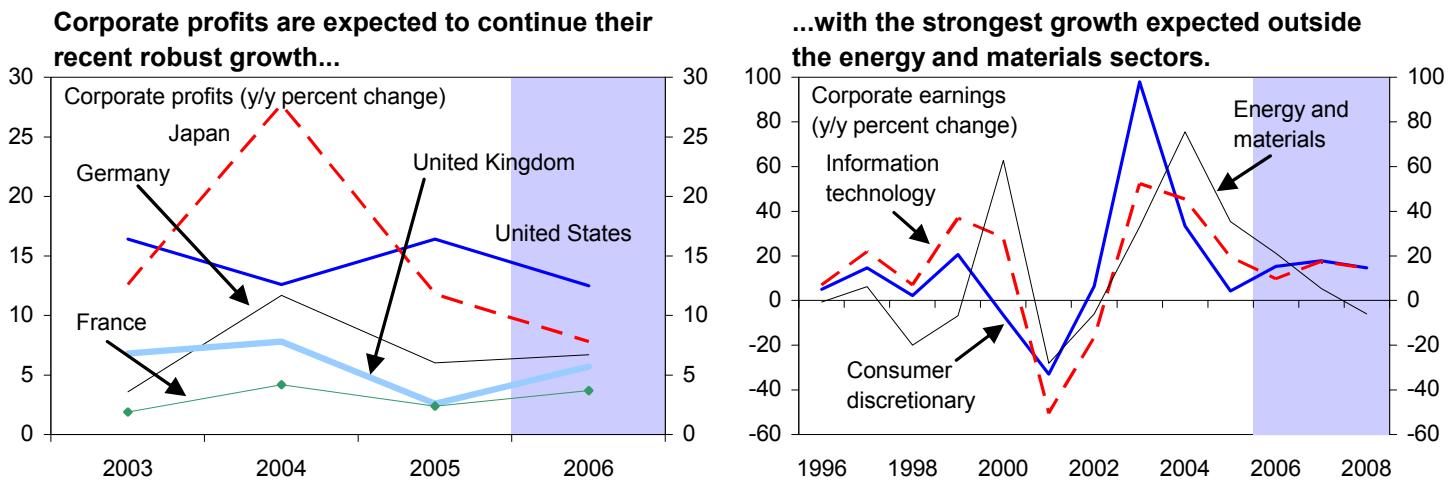

Internal funds generated by firms have
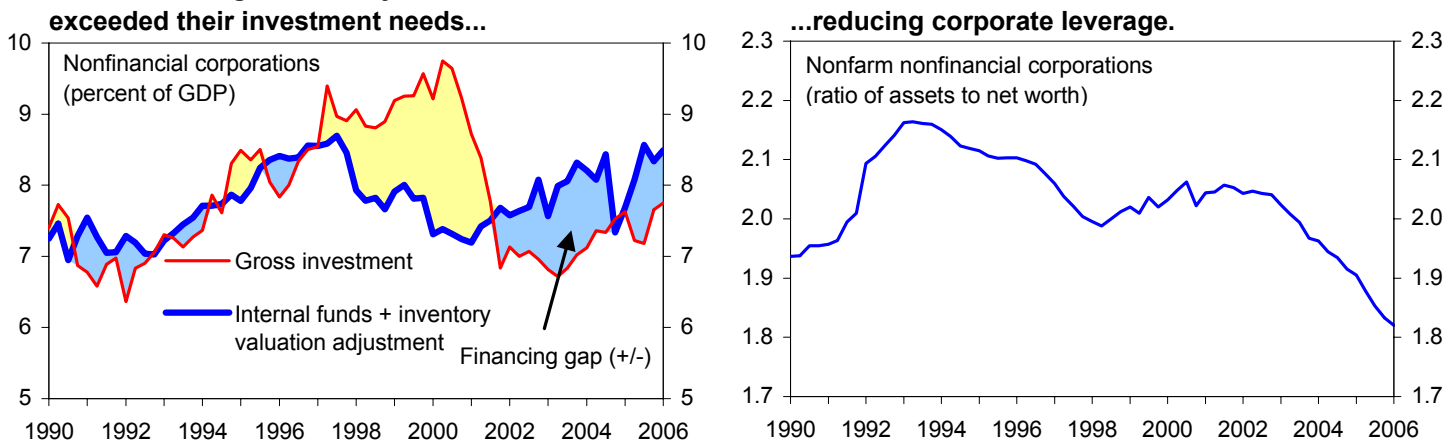

With equity valuations back to pre-bubble levels...

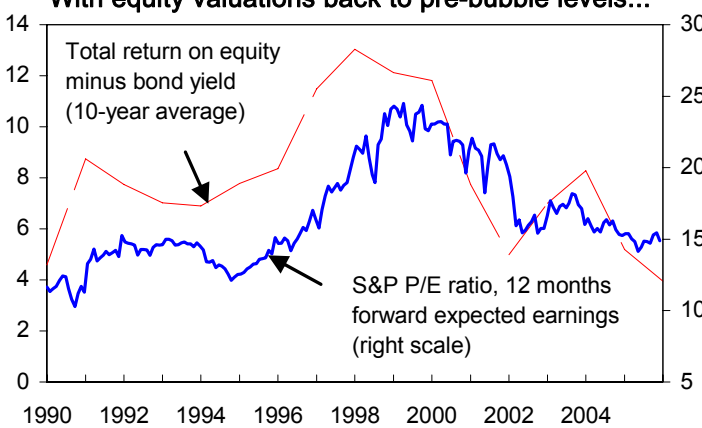

...equity buybacks have exceeded debt

issuance.

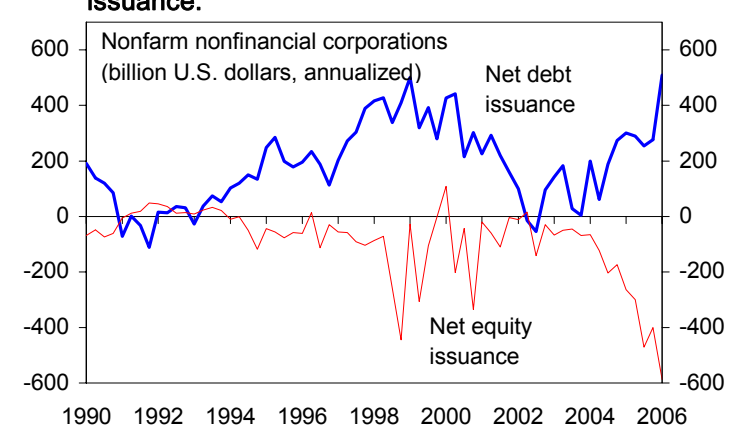

Real investment growth has been strong...
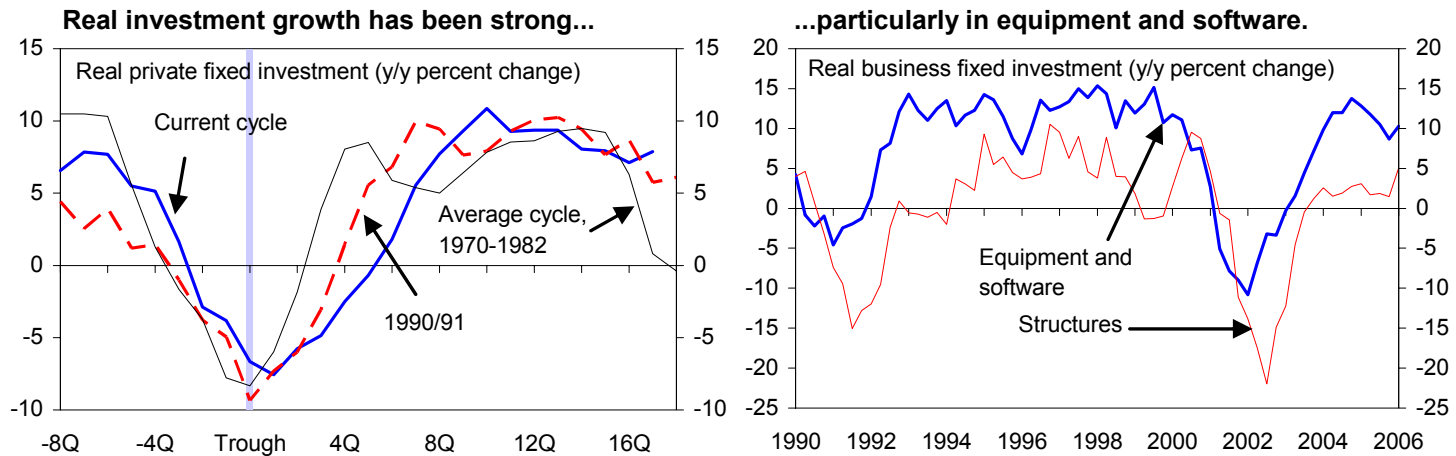

Sources: Haver Analytics; Thomson One Analytics; Consensus Forecasts; and Fund staff calculations. 
Figure 5. Labor Market Indicators

Employment growth has recently outpaced that in other countries...

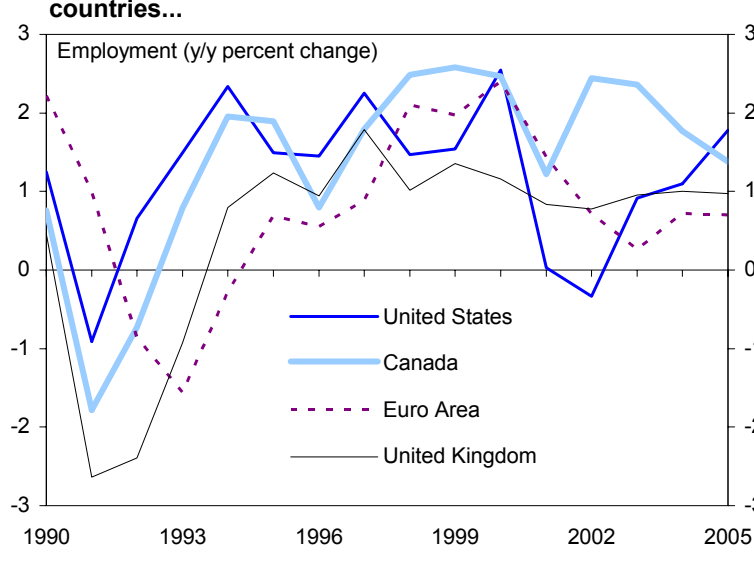

...but has been weaker than during past recoveries...
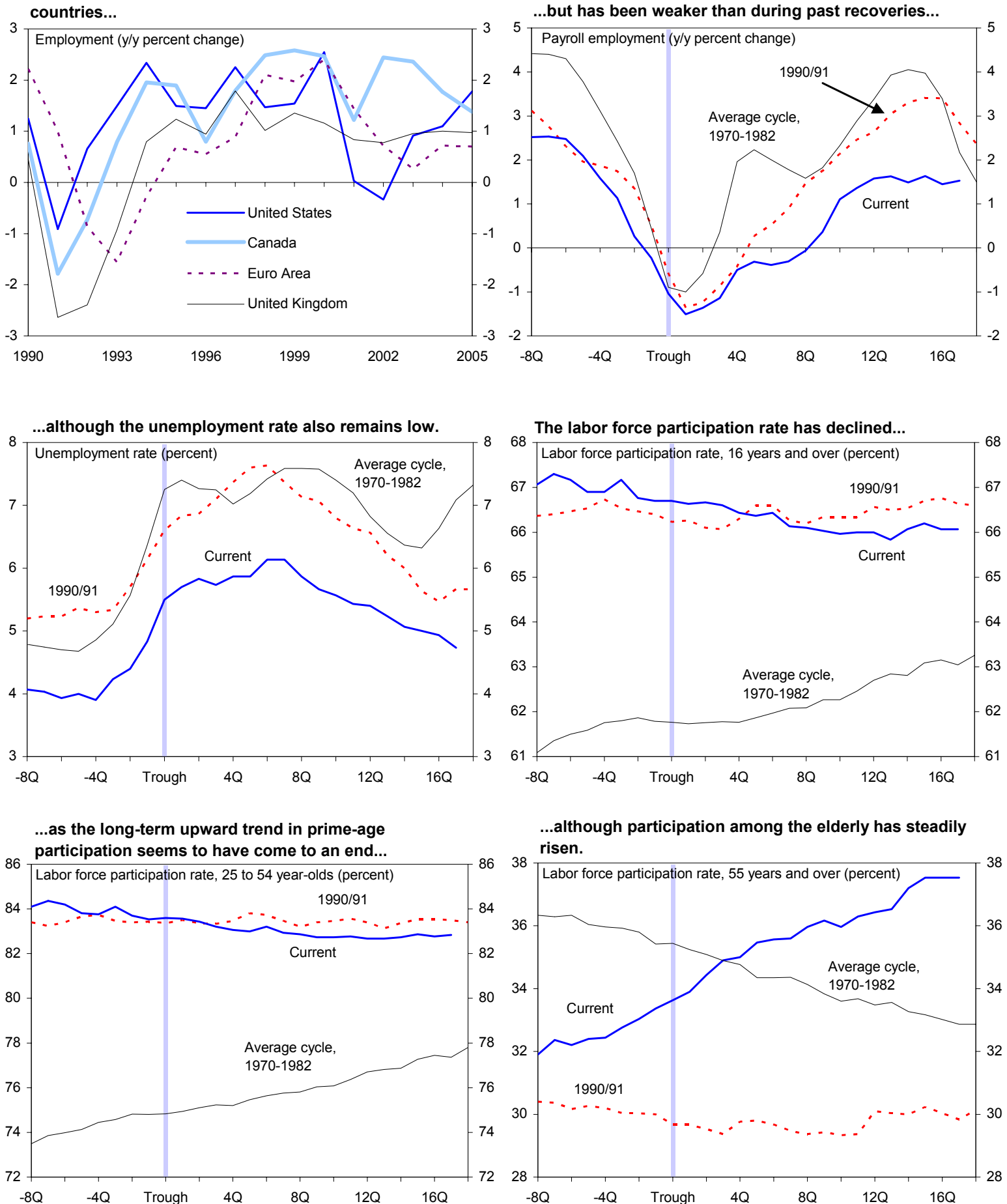

Sources: Haver Analytics; World Economic Outlook; and Fund staff calculations. 
Figure 6. Monetary Policy Indicators
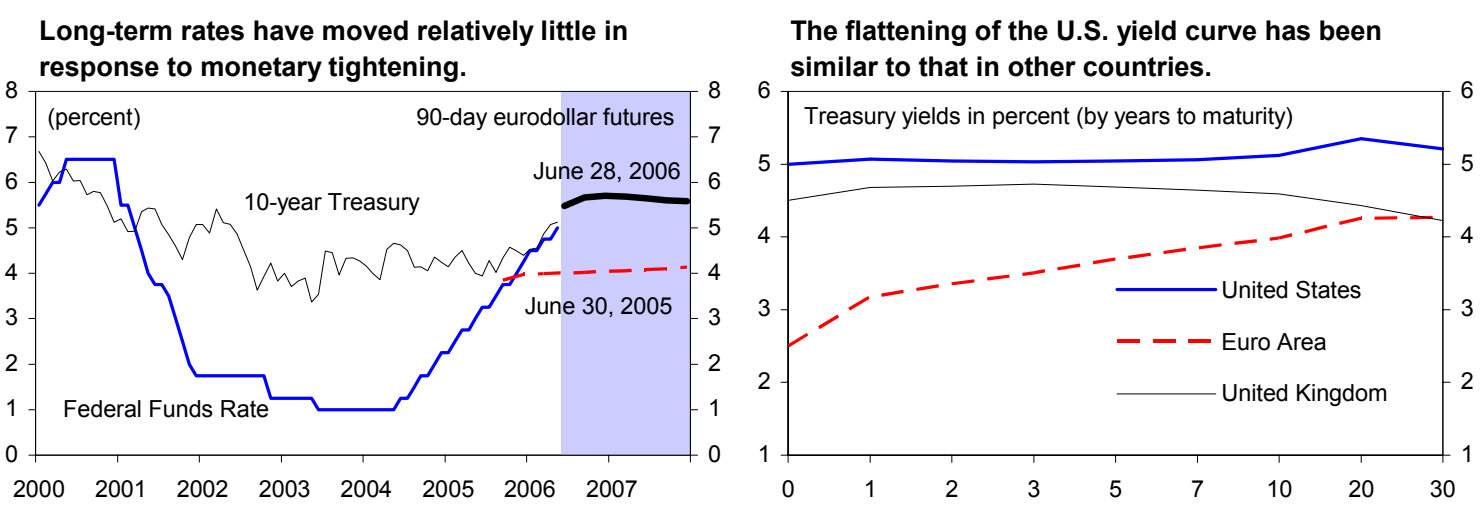

Rising energy prices have not fed into core inflation...
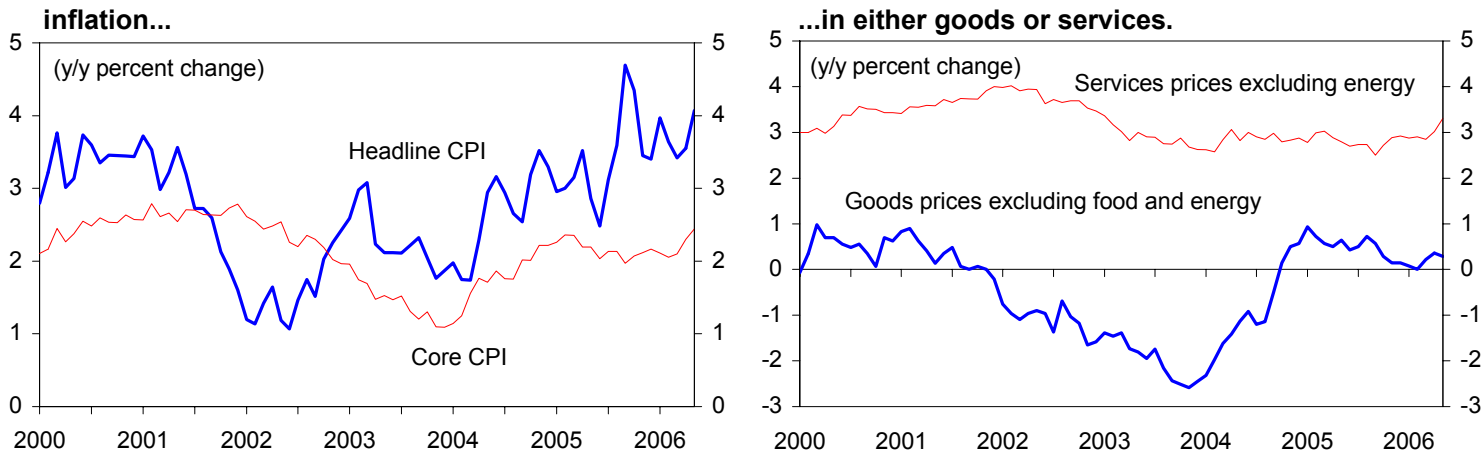

Wage growth has picked up as slack in the labor
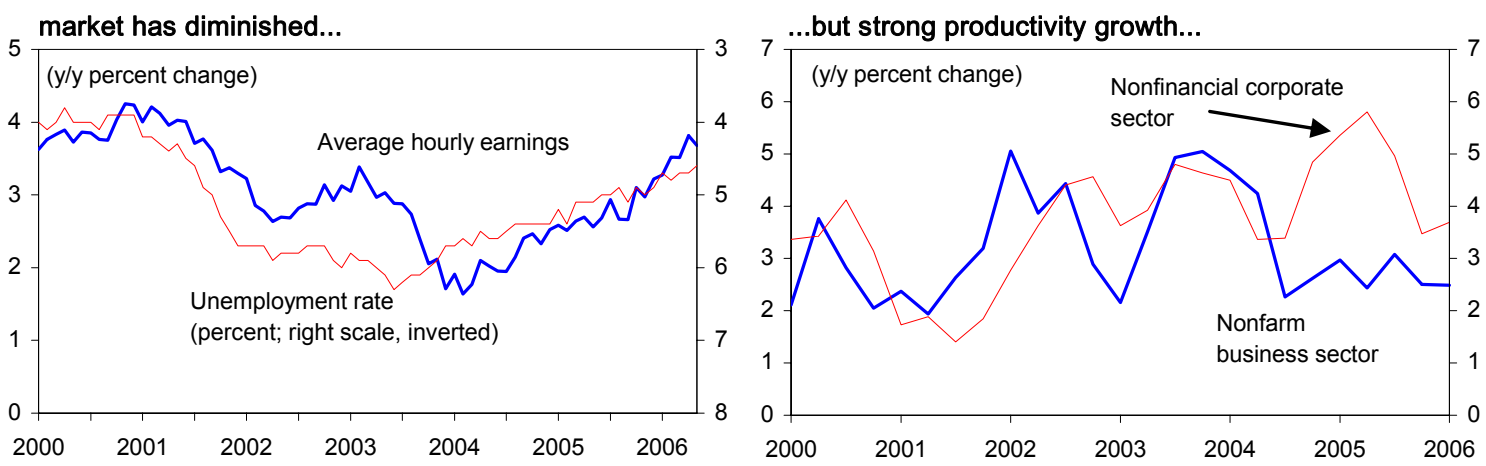

...has kept unit labor costs consistent with low and stable inflation...

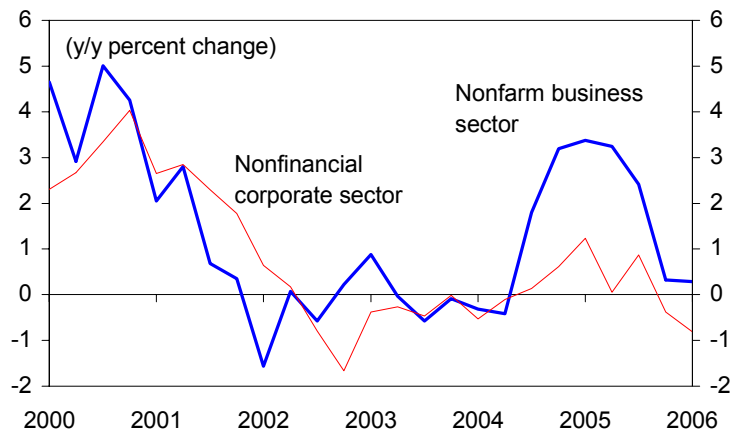

..and inflation expectations are anchored despite some near-term volatility.

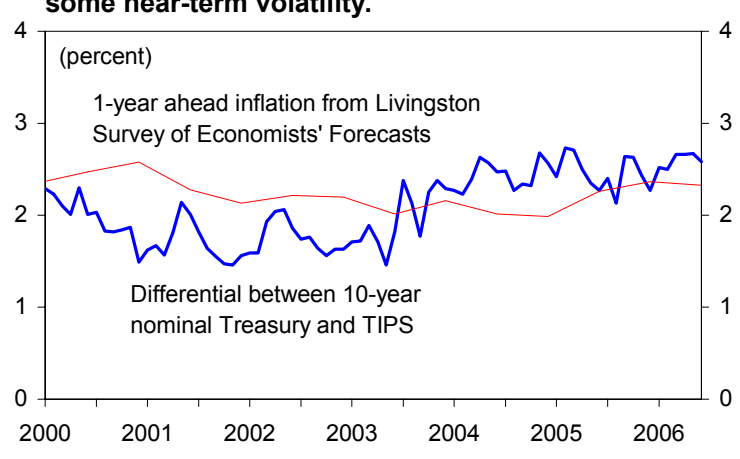

Sources: Bloomberg L.P.; Haver Analytics; and Fund staff calculations. 
Figure 7. Financial Market Trends
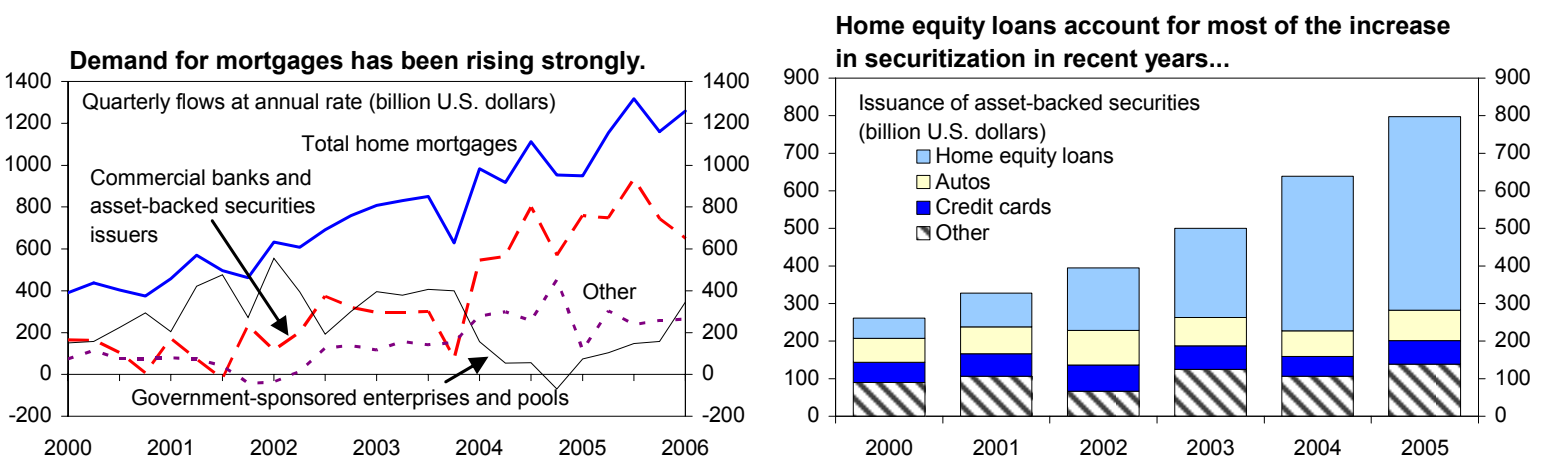

...which has helped raise the share of U.S. asset-

backed securities in the global debt market.
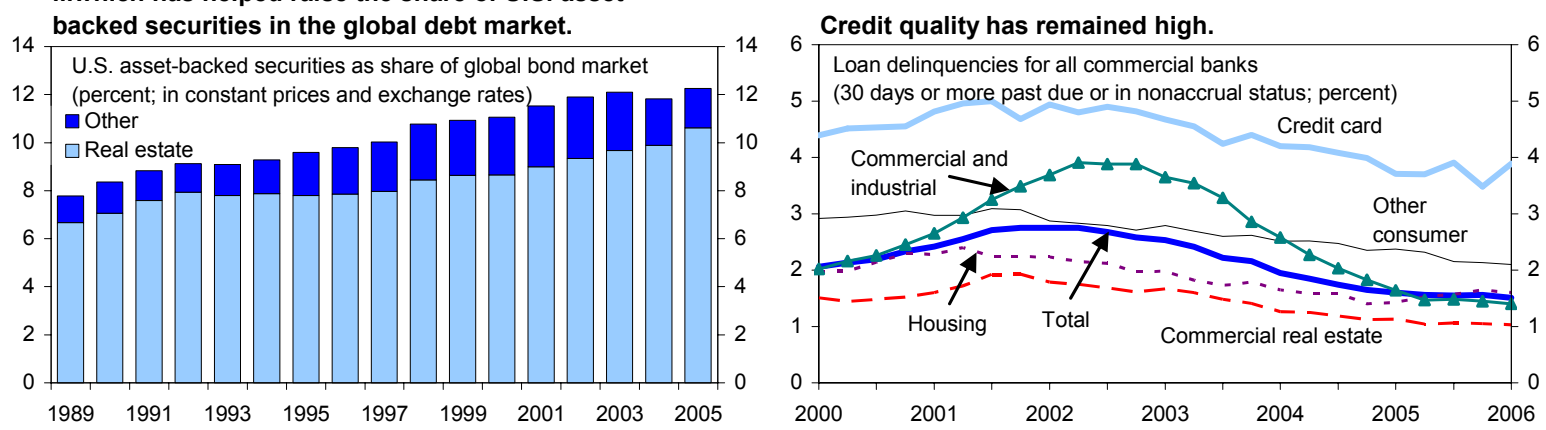

Assets under management by hedge funds have

increased...

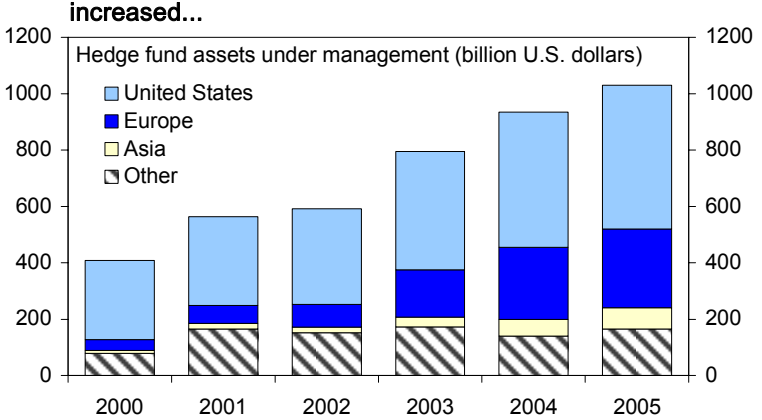

...and they are playing a significant role in certain

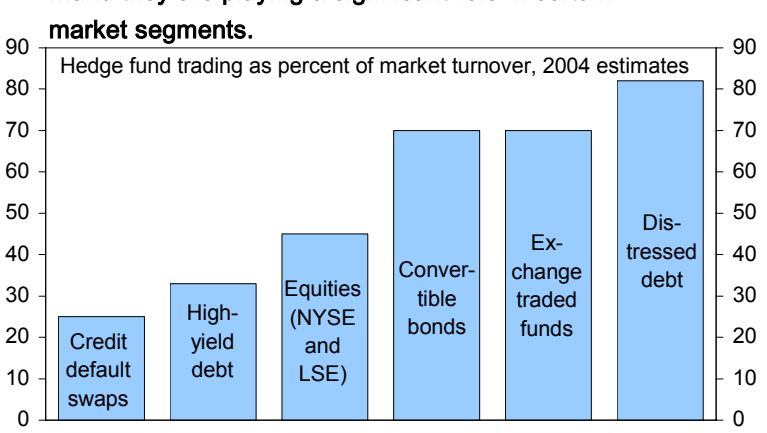

Consistent with strong balance sheets, corporate risk spreads remain well below their post-2000 levels...

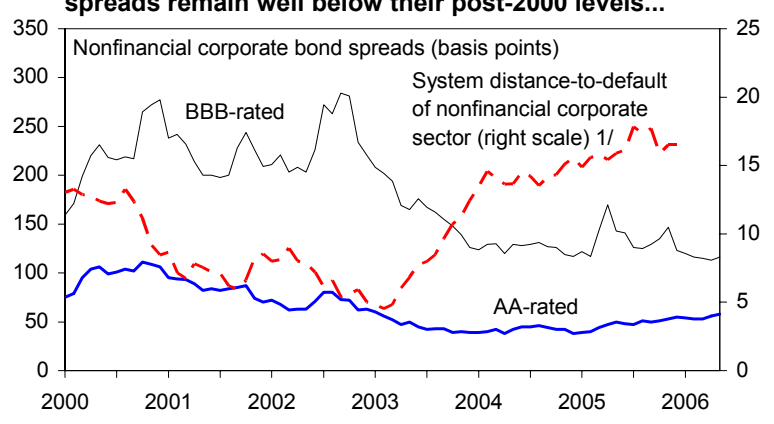

...but significant corporate pension liabilities have accumulated.

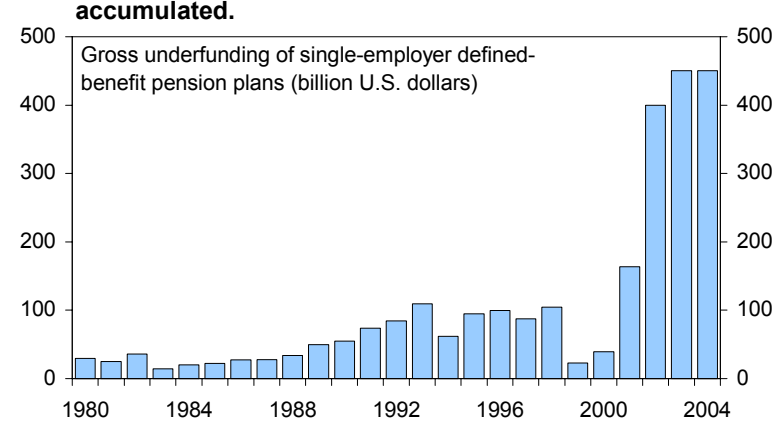

Sources: Haver Analytics; J.P. Morgan; Bank for International Settlements; Securities Industry Association; Moody's Investor Services; Merrill Lynch; Pension Benefit Guaranty Corporation; Datastream; and Fund staff calculations.

1/ For a discussion of distance-to-default measures, see Chapter 6 of United States: Selected Issues (IMF Country Report 04/228). 
Figure 8. Financial Sector Soundness Indicators

U.S. large complex banking groups (LCBG) are exceptionally profitable by international standards...
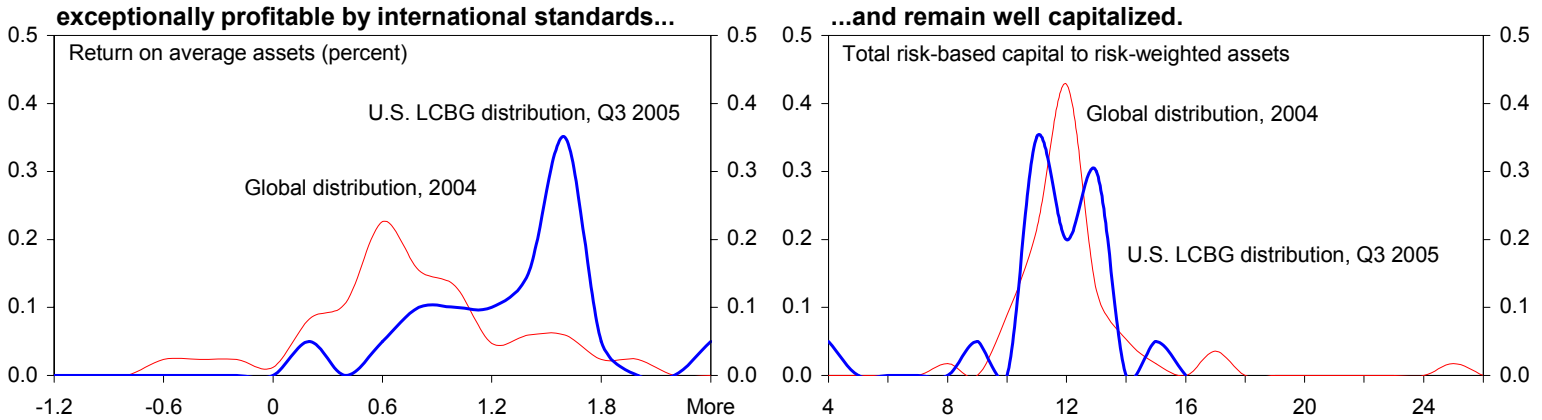

Net interest margins have declined, but noninterest income remains strong...

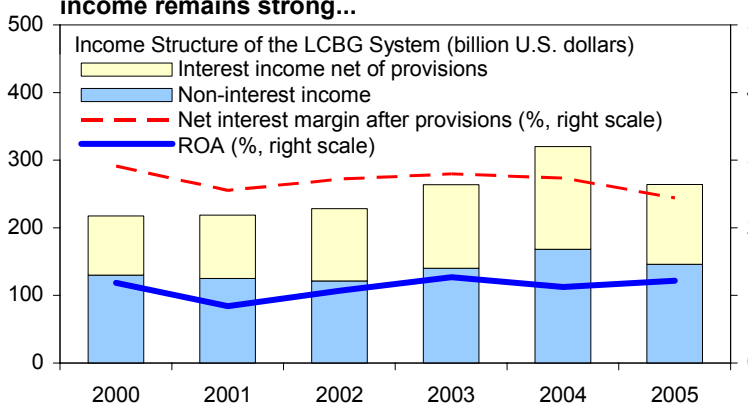

...and banking remained highly profitable, including compared to insurance.

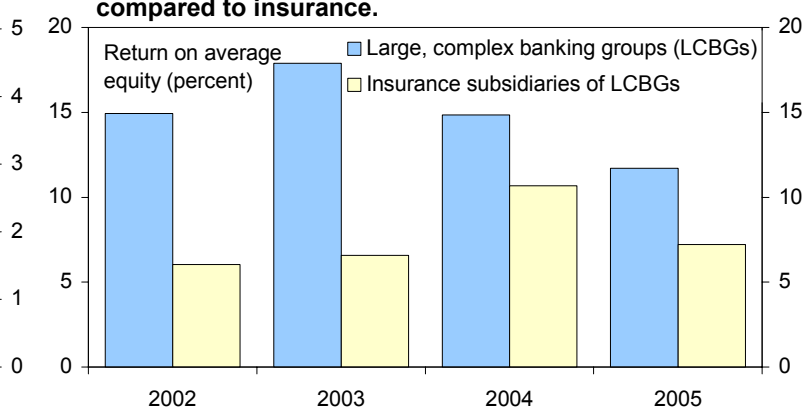

Market risk indicators for large U.S. financial
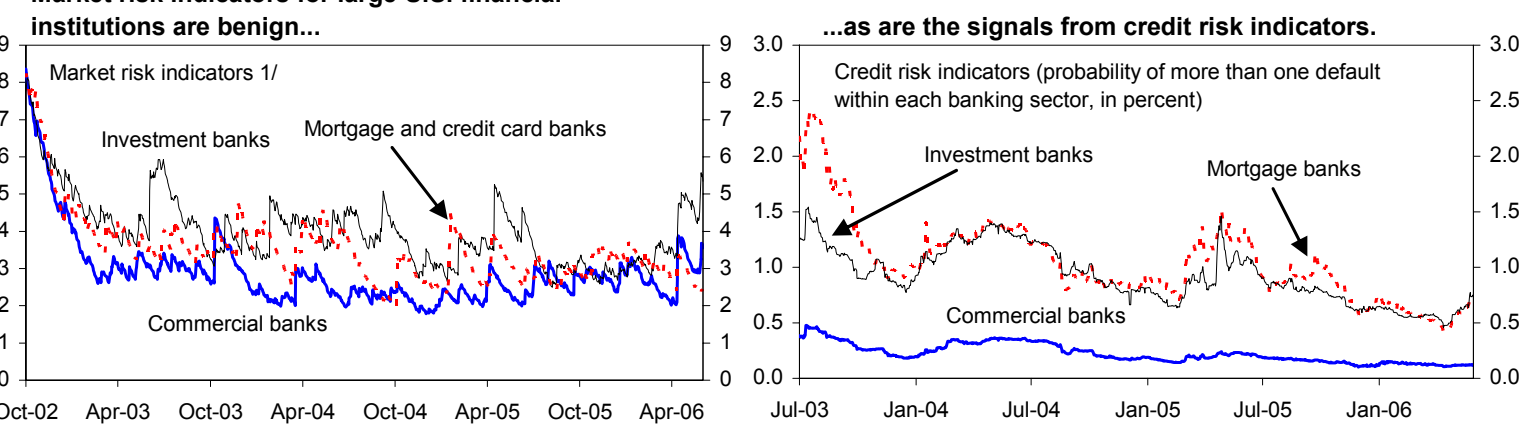

Distance-to-default measures indicate growing diversification gains across LCBGs...

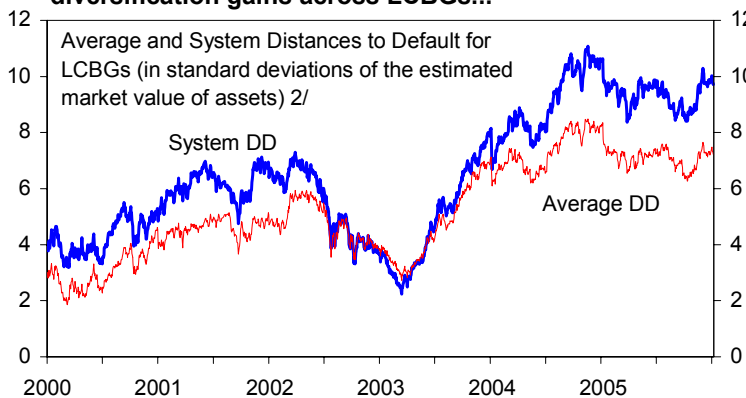

....and point to improving soundness for most segments of the financial sector.

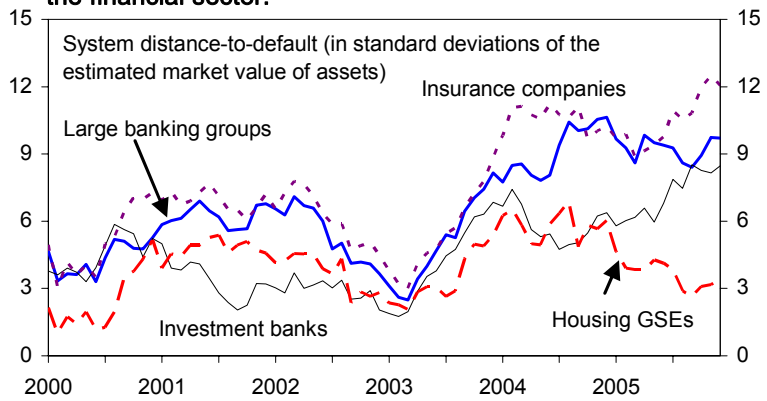

Sources: Bankscope; Datastream; Bloomberg L.P.; and Fund staff estimates.

$1 /$ Value-at-Risk without market effects for portfolio of equities issued by subset of banks, in percent.

2/ For a discussion of distance-to-default measures, see Chapter 6 of United States: Selected Issues (IMF Country Report 04/228). 
Figure 9. External Developments

The current account deficit has widened, with little apparent impact of recent exchange rate depreciation...

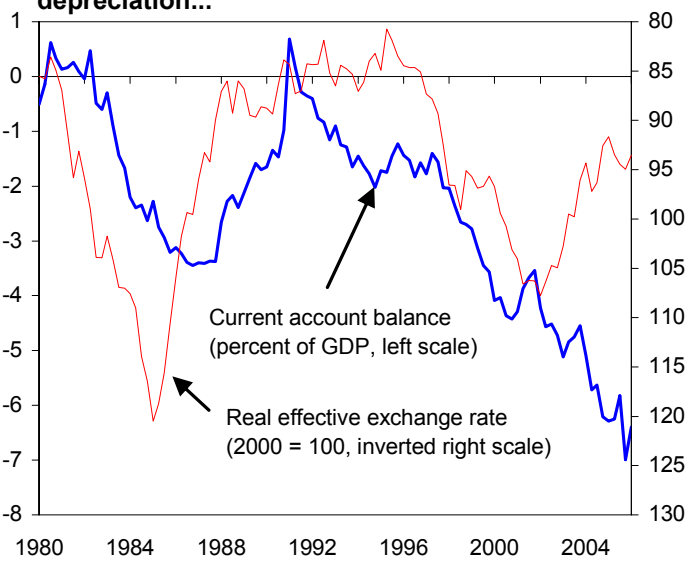

Financing has shifted toward fixed income instruments...

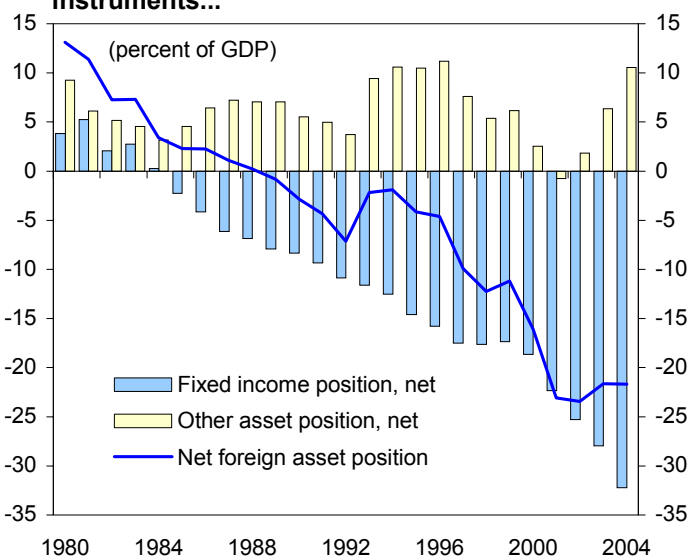

...as real import growth has tended to exceed real export growth in recent years.

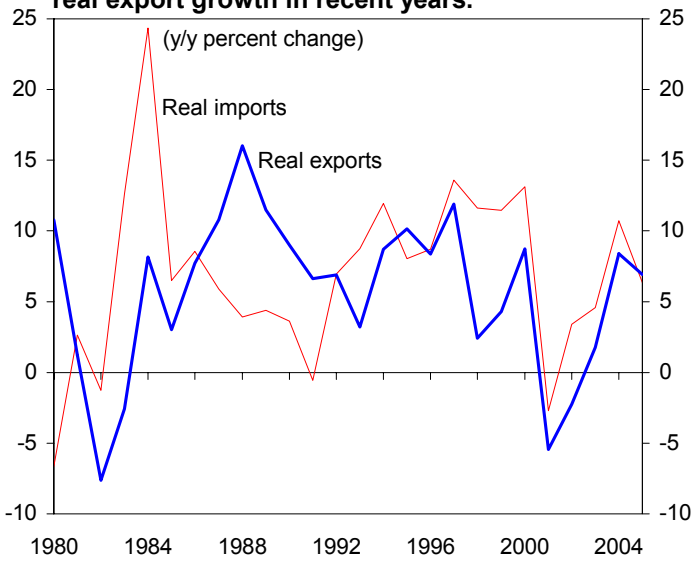

...with official flows playing an important, but diminishing, role in 2005.

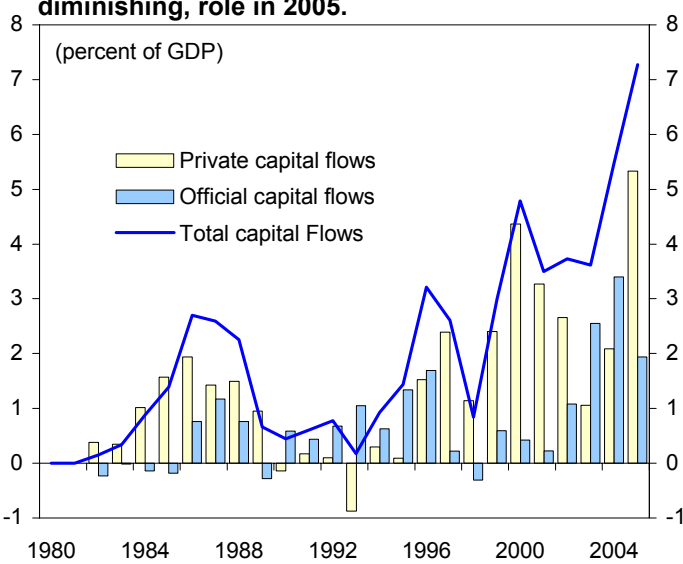

The U.S. current account deficit mirrors surpluses in Asia and among oil exporters...
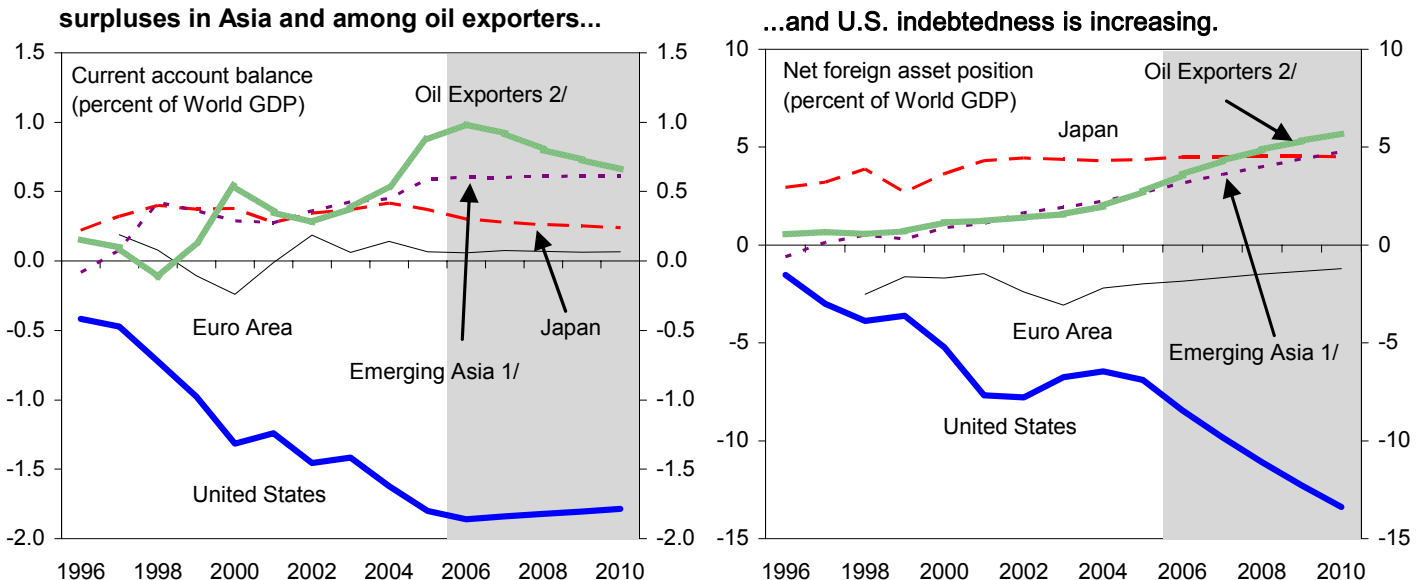

Sources: Haver Analytics; International Financial Statistics; Lane and Milesi-Ferreti (2006); and Fund staff estimates. 1/ China, Hong Kong SAR, Indonesia, Korea, Malaysia, the Philippines, Singapore, Taiwan Province of China, and Thailand. 2/ Algeria, Angola, Azerbaijan, Bahrain, Republic of Congo, Ecuador, Equatorial Guinea, Gabon, I.R. of Iran, Kuwait, Libya, Nigeria, Norway, Oman, Qatar, Russia, Saudi Arabia, Syrian Arab Republic, Turkmenistan, United Arab Emirates, Venezuela, and the Republic of Yemen. 
Figure 10. Indicators of International Competitiveness
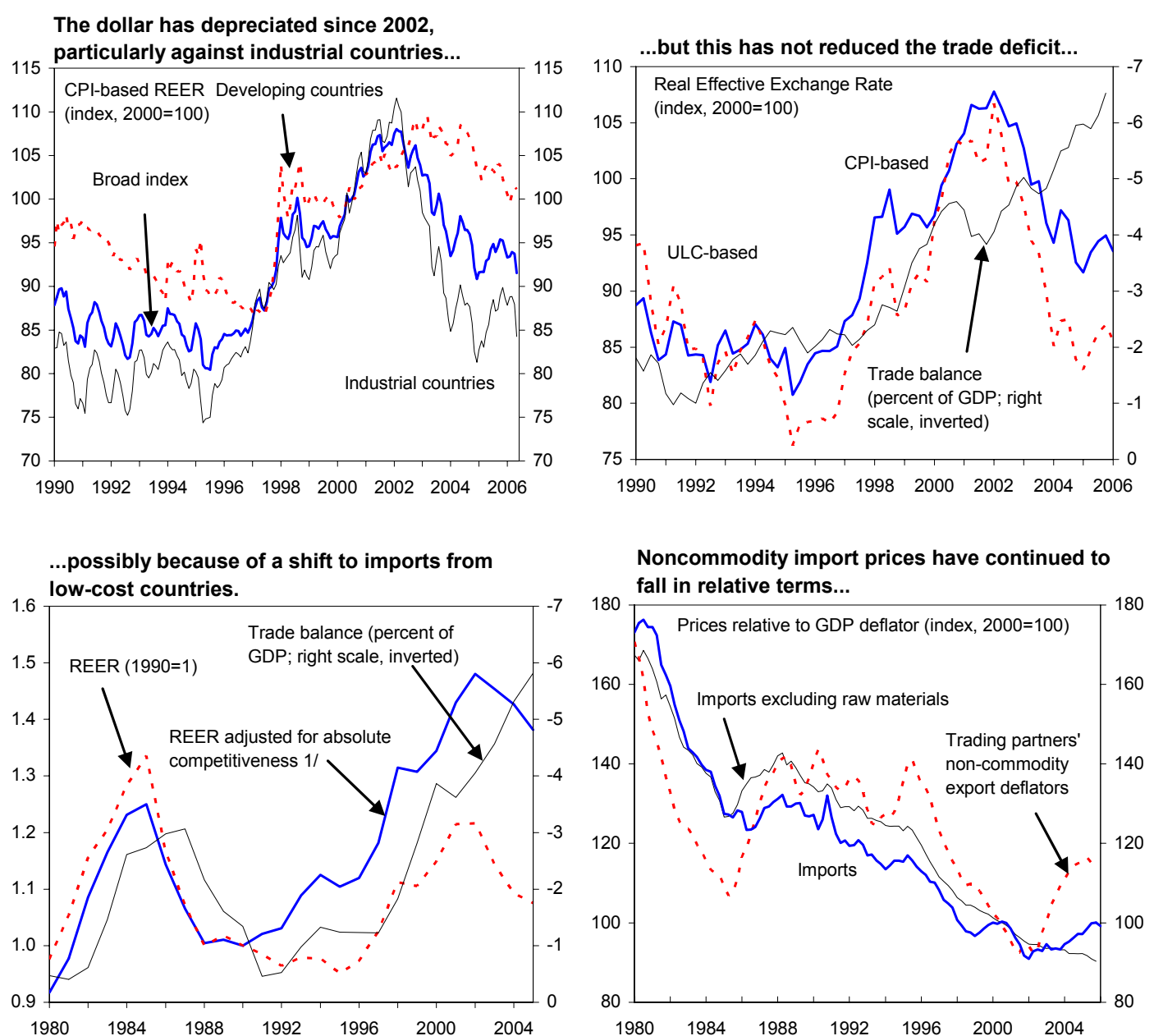

Noncommodity import prices have continued to fall in relative terms...
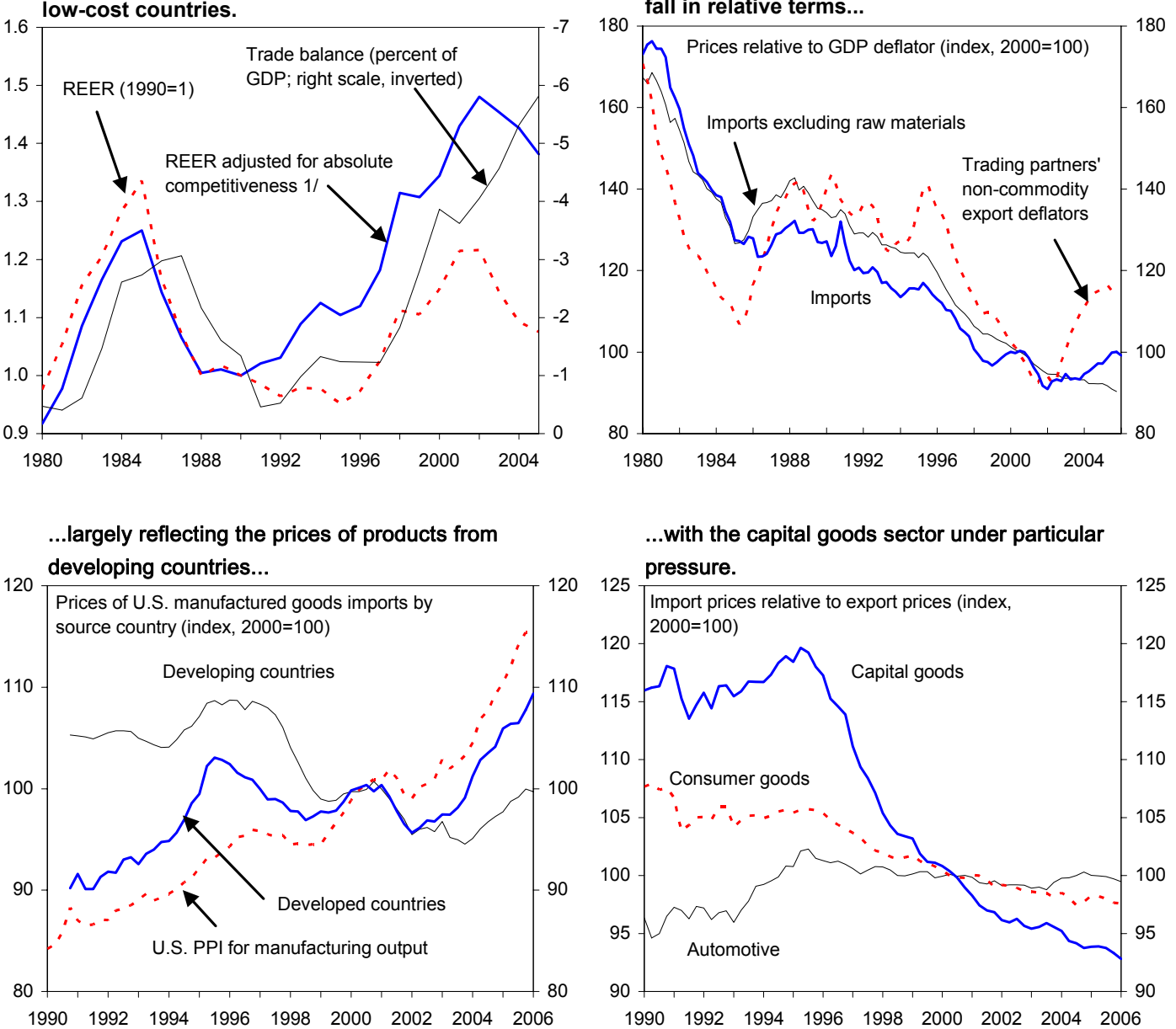

Sources: Haver Analytics; IMF, World Economic Outlook; and Fund staff calculations.

$1 /$ Trade-weighted index using deviations from PPP to measure competitiveness. 
Figure 11. Fiscal Indicators

Given the economy's cyclical position, the U.S. fiscal deficit remains large.

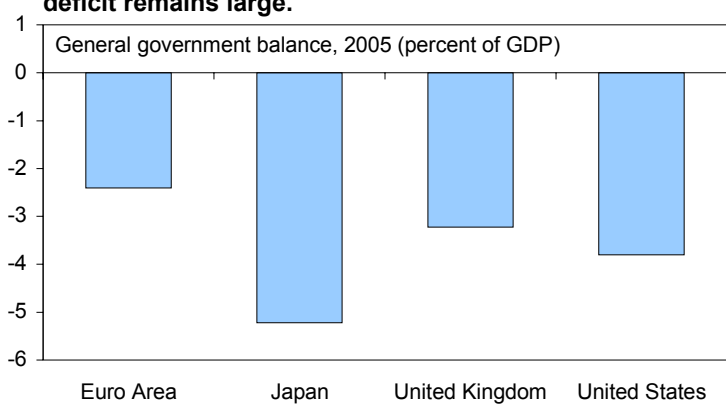

Official projections suggest that the aging of the

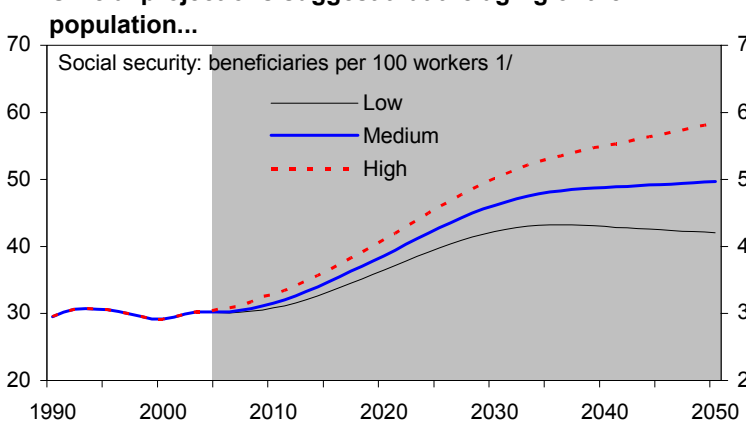

...will lead to rapidly increasing entitlement spending.
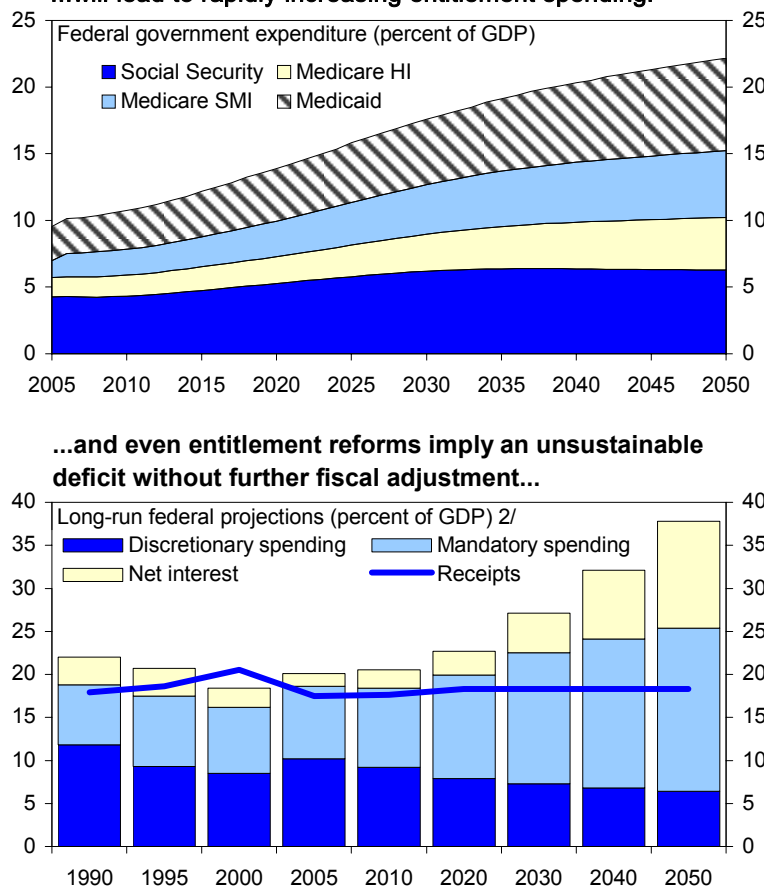

...and medium-term prospects for fiscal consolidation appear limited.

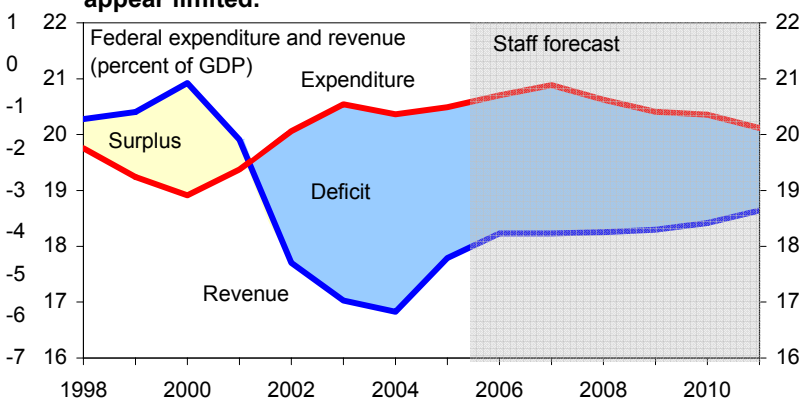

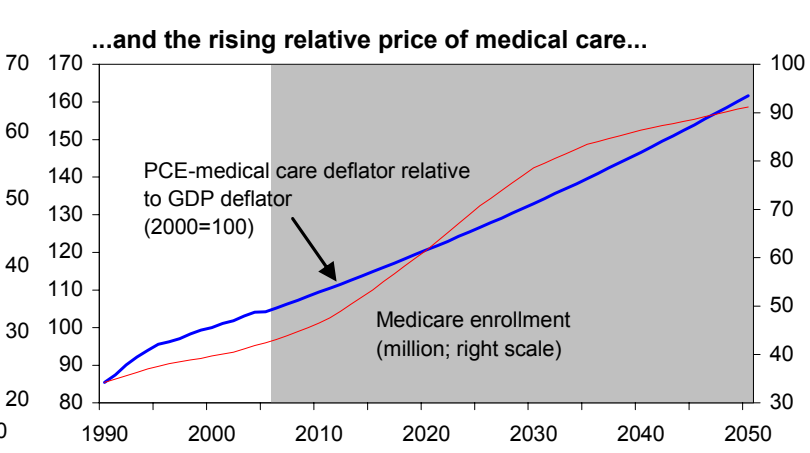

Medicare and Social Security spending will exceed payroll taxes and become a drain on other revenues...
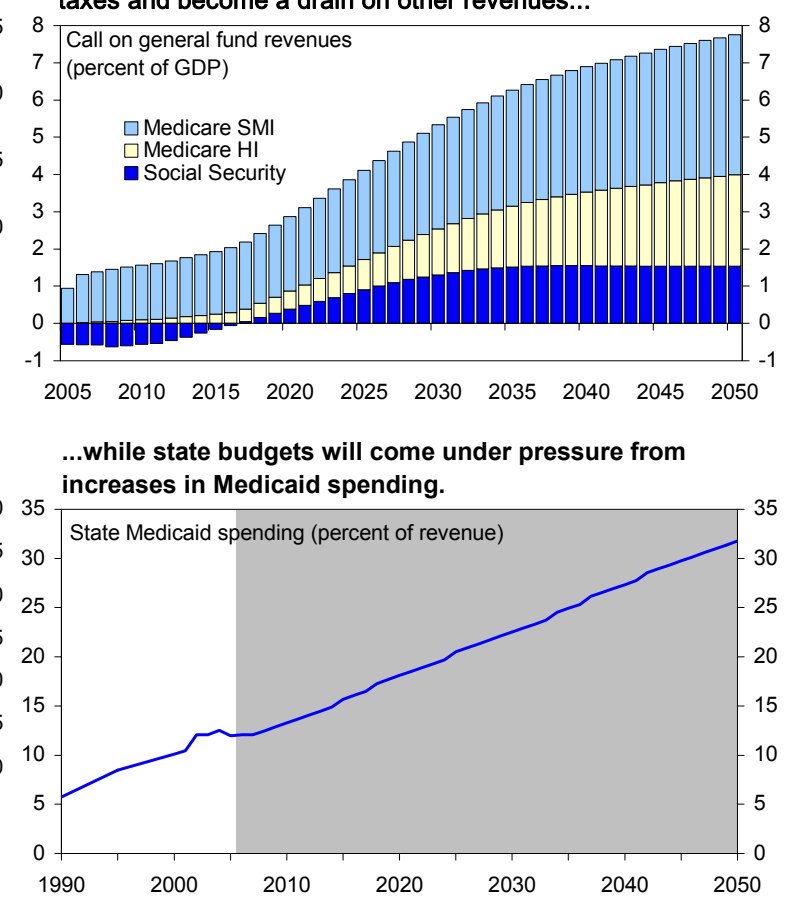

Sources: Haver Analytics; OECD; Social Security and Medicare Boards of Trustees; Congressional Budget Office (CBO); Office of Management and Budget; and Fund staff calculations.

$1 /$ The three paths are based on differing demographic assumptions.

2/ CBO projections, December, 2005. 
Figure 12. Fiscal Indicators in an International Setting
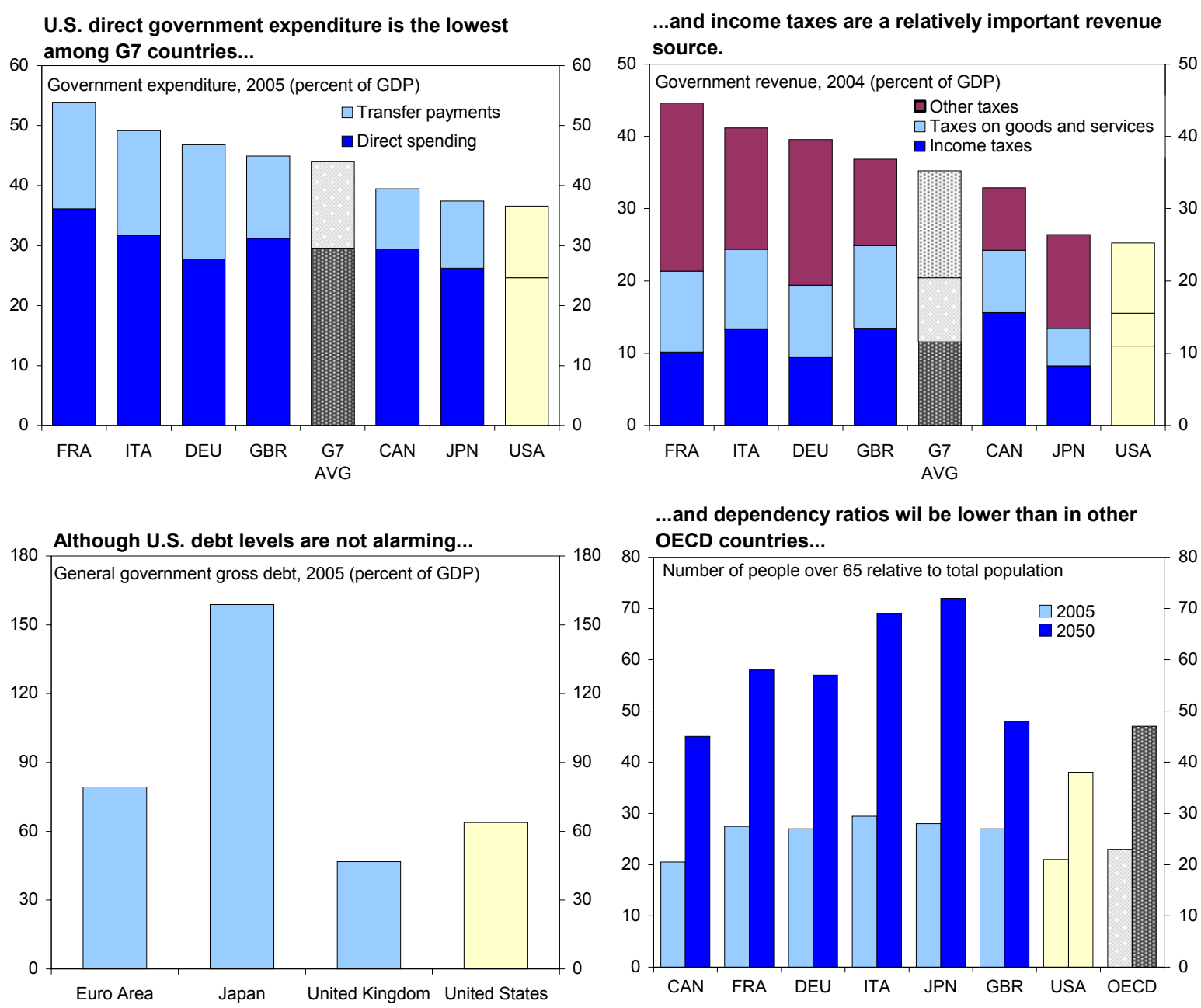

...and dependency ratios wil be lower than in other OECD countries...

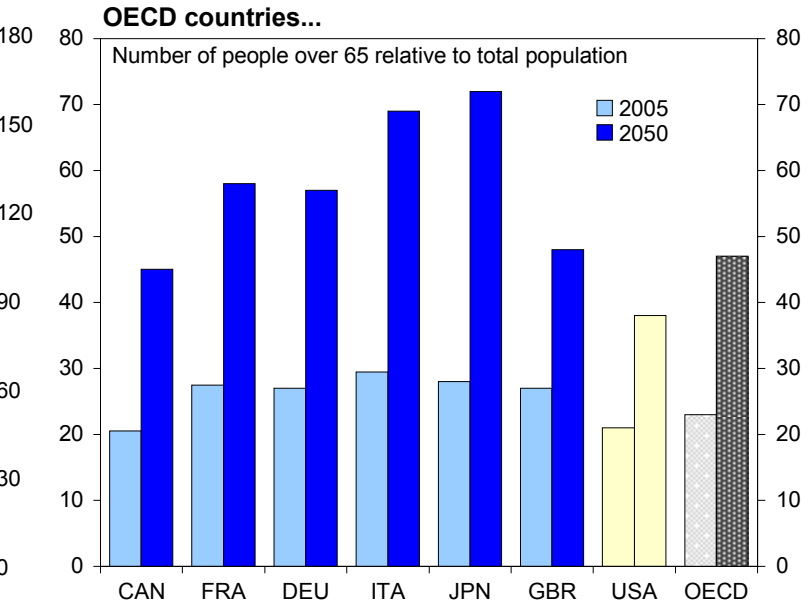

...spending pressures from health care are set to rise significantly..
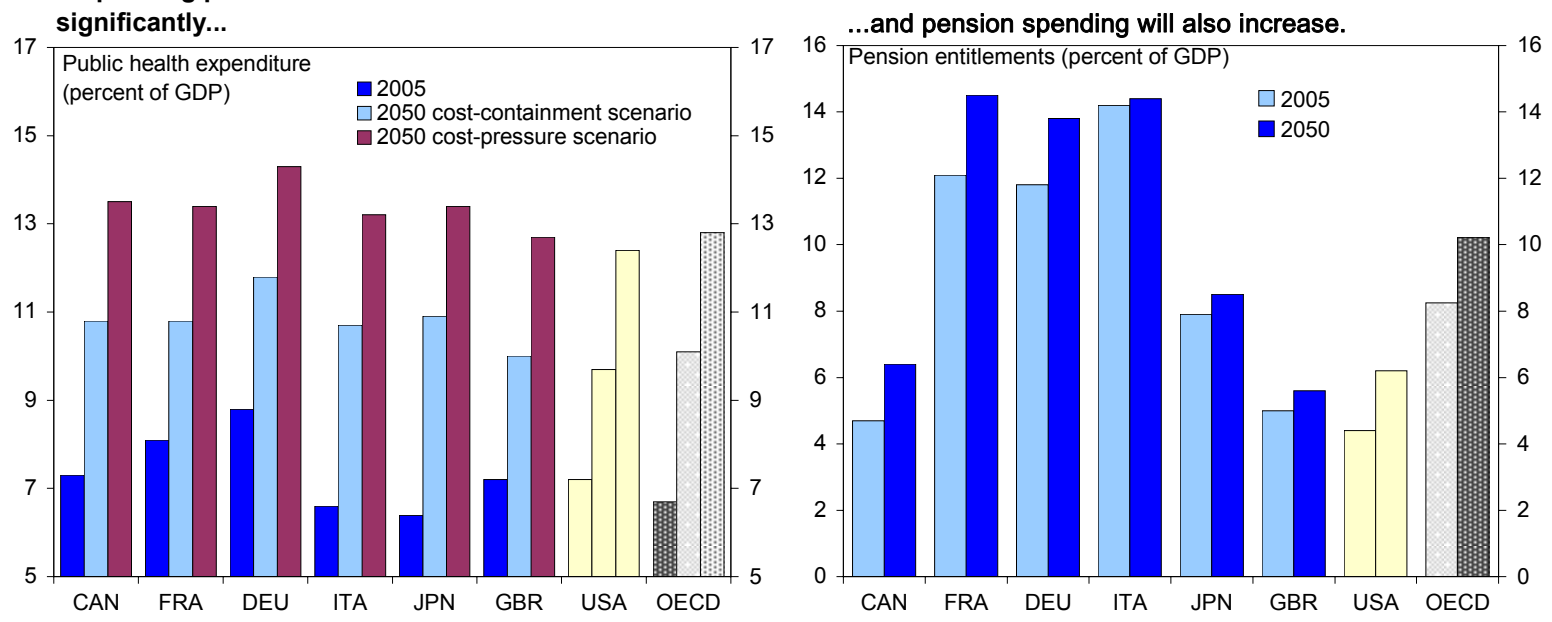

Sources: OECD; and IMF, World Economic Outlook. 


\section{Figure 13. Health Care Indicators}
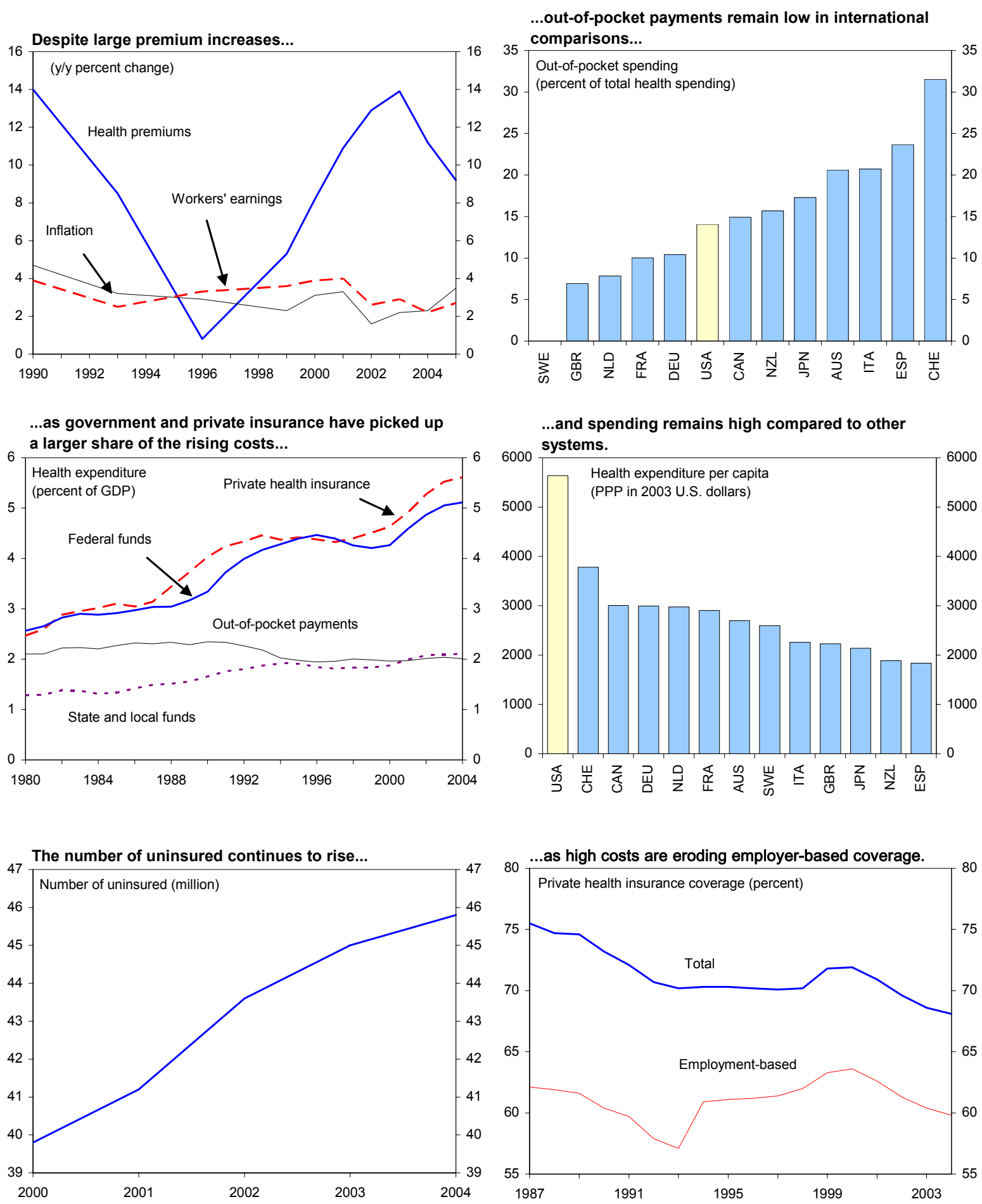

Sources: U.S. Department of Health and Human Services; OECD; Health Research and Educational Trust; and Kaiser Family Foundation. 


\section{Understanding Fan Charts}

The fan charts in Figure 1 summarize staffs' assessment of the overall impact of risks to baseline GDP growth and CPI inflation forecasts. The uncertainty around the baseline (which reflects the "most likely" outcome) is captured by the fan chart's width, while the balance of risks - up or down - is reflected in its asymmetry. For example, the growth fan chart is negatively skewed, suggesting downside risk to staff's baseline growth forecast.

\section{Two key inputs are required to construct a fan chart:}

- A measure of the inherent reliability of the baseline forecast. Staff used the standard deviation of the forecast error, calculated from the growth forecast errors in the April World Economic Outlook over 1992-2005.

- The balance of risks to the baseline forecast. Staff assessed four risks to baseline growth, stemming from the housing market, labor productivity, financial conditions (all of which were assessed to produce downside risks to growth), and corporate spending (an upside risk). Staff also considered the impact of unlikely "discontinuous" events with large effects on growth — an Avian flu pandemic, other geopolitical risks (including a sharp spike in oil prices), and a disorderly unwinding of global imbalances. The balance of risks for 2006 implies that the average (mean) forecast for growth is $1 / 4$ percent below the staff's most likely (mode) forecast, and this difference rises further in 2007.

To provide a sense of the assumptions underpinning a specific risk imbedded in the growth fan chart, it is useful to elaborate on the risks to growth stemming from the U.S. housing market in 2006 - the largest "continuous" risk to the baseline forecast. The baseline growth forecast assumes real house price growth will slow to 5 percent in 2006, implying a drag on GDP growth from the housing market of approximately $1 / 2$ percent in 2006 and in 2007.

Staff then assessed two extreme but equally likely outcomes in the housing market. A downside risk is that nominal house prices will remain unchanged over the next year (real prices fall moderately) and residential investment growth turns negative. In this case, assuming a larger housing wealth effect of 10 cents in the dollar owing to a rapid slowdown in home equity withdrawal, GDP growth is expected to fall by 1 percent relative to the 2006 baseline. Staff also considered an upside risk that house price inflation and activity in 2006 remains the same as in 2005, implying a $1 / 2$ percentage point higher GDP growth than in the baseline forecast.

Risks to inflation were considered to be on the upside. The downside risks associated with the potential for lower activity were offset by the potential boost to unit labor costs from slower-than-expected productivity growth. The upside risk comes from adding the possibility that high oil costs would be passed through to prices. 


\section{Summaries of BACKground Work ISSUed As Working PAPERS}

\section{Is Housing Wealth an 'ATM'? The Relationship between Household Wealth, Home Equity Withdrawal, and Saving Rates \\ by Vladimir Klyuev and Paul Mills (WP/06/162)}

The increase in U.S. home equity withdrawal (HEW) in recent years is often associated with the decline of the U.S. household saving rate. HEW is net new household borrowing secured on dwellings in excess of actual investment in housing. HEW increased from around 1 percent of U.S. net disposable income in the early 1990s to 9 percent in 2005-a period during which the ratio of household saving to disposable income fell from 7 percent to minus 0.5 percent. Some analysts have therefore argued that U.S. households have mainly used HEW to finance consumption, whereas others contend that HEW has been used to acquire financial assets, with lower saving a consequence of rising household wealth.

The paper analyzes the relationship between $\mathrm{HEW}$, household wealth, and the saving rate for four countries. Given similar trends in home ownership, personal wealth and saving in the United States, Australia, Canada, and the United Kingdom, the paper investigates whether developments in these countries can shed light on the future path for U.S. HEW and household saving.

\section{Trends in HEW}

All countries have experienced considerable financial innovation, which has improved access to home equity. Mortgage market innovations in all four countries mean that, to varying degrees, borrowing constraints on middle- and low-income households have been relaxed, the cost of refinancing has fallen, and housing equity can be accessed at lower transactions costs. This is illustrated by the increasing share of secured credit in household debt in the United States. The increase in the liquidity of home equity is also likely to reduce the volatility of consumption and increase the attractiveness of owning a home by making it a more readily accessible store of value.

\section{However, HEW does not appear to have played a consistent role across countries:}

- While the decline in personal saving has been relatively similar, HEW trends have differed markedly across countries. In the United States, HEW has been on an upward trend since the mid-1990s, consistent with the stylized fact that HEW tends to rise with housing market turnover and real house price inflation. HEW has exhibited a more cyclical pattern in the U.K. and Australia, with the latter also showing some trend increase. In Canada, the household sector in aggregate has almost never withdrawn equity from their housing assets.

- Survey evidence indicates that HEW is used for a variety of purposes, with consumer spending taking only a modest share. Evidence from the United States, 
the U.K., and Australia indicates that acquisition of financial assets and repayment of other debts constituted the principal uses of HEW, with about 15-25 percent of withdrawn equity being used to finance consumption. In these surveys, a similar amount is used for home improvement, which is counted as residential investment and is not included in the national accounts definition of HEW.

The link between $\mathrm{HEW}$ and the net acquisition of financial assets by households is less clear in the aggregate data. Unlike the synchronous rise in HEW and decline in the personal saving rate, the acquisition of financial assets in the United States, Australia, and the United Kingdom has not exhibited a clear trend. In Canada, household saving declined against the background of growing home equity injection and a declining flow into net financial assets.

\section{Regression results}

Regression results indicate that $\mathrm{HEW}$ does not affect household saving rates in the long run, including in the United States. In the long run, the personal saving rates are largely determined by the ratio of household net worth to disposable income, the real interest rate, and the inflation rate. A time trend, probably reflecting financial market liberalization and innovation, also helps to explain the path of the U.S. saving rate.

Regressions do suggest, however, that HEW may have a notable short-run effect on saving. Changes in HEW are estimated to lead to a 15-20 cents in the dollar temporary offset on U.S. household saving, consistent with the survey evidence, although the impact is not statistically significant. Results for other countries vary, with the U.K. regression indicating a larger (and significant) effect, while the effects in Australia and Canada are estimated to be somewhat smaller than in the in the United States and insignificant.

\section{Policy implications}

Accessing housing wealth through HEW appears to have a short-term impact on household saving, while long-term trends are dominated by changes in household wealth and real interest rates. This presumably reflects the fact that different forms of wealth are increasingly fungible over time. One implication is that mortgage market innovation - such as lower transaction costs and easier access to home equity - may well increase the level and volatility of HEW, but there should be some benefit to macroeconomic stability from allowing households to more effectively smooth consumption over time.

Turning to the current conjecture, the likely fall in HEW as the housing market cools should support some rise in the U.S. household saving rate. Recent experience in the U.K. and Australia indicates that HEW could fall significantly as the housing market decelerates. Was HEW to rapidly revert to its long-term average of around 1 percentage point, regression coefficients imply a temporary boost to household saving of 1 percentage point or so, combined with a negative impact on residential investment spending on home improvement. 


\section{U.S. Inflation Dynamics: What Drives Them Over Different Frequencies?} by Ravi Balakrishnan and Sam Ouliaris (WP/06/159)

As in many other industrialized countries, inflation in the U.S. has remained low since the mid-1990s. This favorable outcome has occurred despite generally robust economic growth and substantial oil and commodity price increases.

The academic literature offers only limited explanation for this decline in inflation. Traditional empirical models tend to over-predict inflation, particularly after the mid-1990s, and most researchers have argued that improved monetary policy credibility and increased globalization have contributed to the decline in price pressures.

The paper seeks to improve the understanding of U.S. inflation dynamics by separating structural from cyclical effects, and by studying the impact of external factors. Using data for 1960-2005, frequency domain decompositions reveal that there has been a smooth, secular decline in underlying inflation that started around 1980. The paper also finds a reduction in the size and volatility of the business cycle component of inflation over a similar period, with indications that the growing impact of globalization has played a role in this development.

Two models are used to analyzing the inflation-output tradeoff. The traditional Phillips curve (TPC) focuses on the role of lagged inflation and the output gap on inflation. The forward-looking New Keynesian Phillips Curve approach places more emphasis on expected future inflation and movements in marginal producer costs.

\section{Traditional Phillips Curve}

The TPC model enhances the understanding of cyclical inflation movements but still over predicts inflation. The model produces relatively good forecasts for the business cycle component of inflation. However, even after incorporating external shocks to capture the impact of imported inflation — proxied by movements in the terms of trade - much of the trend decline in inflation is unexplained. This suggests that the decline in inflation since the 1980 s is a structural, as opposed to cyclical, phenomenon.

Several factors are likely to contribute to the model's shortcomings. Apart from ignoring forward-looking inflation expectations, possible shifts in the expectation formation processfor example due to enhanced U.S. monetary policy credibility_-may also play a role. Moreover, significant measurement error in the output gap estimate, especially in view of the apparent increase in structural productivity growth during the second half of the 1990s, may have contributed to the upward bias in inflation projections. 


\section{New Keynesian Phillips Curve}

The New Keynesian Phillips Curve (NKPC) model offers theoretical improvements over the traditional Phillips curve approach. To address some of the shortcomings inherent in TPC models, these models use forward-looking inflation expectations and focus on changes in marginal costs — which should directly affect producers' pricing decisions — rather than measures of the output gap.

Although the NKPC also falls short of explaining the decline in structural inflation, the results suggest that the link between production costs and inflation has weakened over time. Using the labor share in GDP as a proxy for marginal production costs, we find that the relationship between inflation and marginal costs breaks down in the late 1990s - around the same time the TPC model starts to over-predict inflation. This finding is robust to changes in the definition of the labor share, such as stripping out stock options from labor income.

External variables improve the fit of the NKPC, providing support to the hypothesis that trade and global factor markets have helped to reduce inflation. The basic model was extended by introducing imported intermediate goods and allowing desired price mark-ups to vary with the business cycle and the degree of competition. This improved the overall performance of the model, although the impact and significance of external variables are evident mainly in the cyclical component.

\section{Policy implications}

The paper finds that downward price pressures related to globalization appear to be largely cyclical in nature, suggesting that their beneficial impact on inflation could wane earlier than expected. The decomposition of inflation into its cyclical component and secular trend components reveals that excess demand, terms-of-trade shocks, and competitive pressures linked to globalization operate mainly over the cycle. The result for globalization is particularly important, as it suggests that competitive effects coming from low-cost producers and higher global competition are unlikely to keep inflation low on a permanent basis.

This suggests that preserving and strengthening monetary policy credibility will be key to cementing the secular decline in inflation. Given the limited role identified for other factors, higher credibility not only appears to have contributed to the trend decline in inflation but also to have lowered the variability of inflation around its long-run path. Pinning down the structural and cyclical implications of monetary policy credibility will be an important project for future research. 


\section{U.S. Dollar Risk Premiums and Capital Flows \\ by Ravi Balakrishnan and Volodymyr Tulin (WP/06/160)}

Although the U.S. current account deficit has so far been easily financed, questions about the availability of future financing have been mounting. Following a steady deterioration since the early 1990s, the U.S. current account deficit reached a record $6 \frac{1}{2} 2$ percent of GDP in 2005. While this has been financed without placing any obvious pressure on U.S. interest rates or the dollar, many analysts and policymakers have cautioned that the current trajectory of U.S. net foreign liabilities is unsustainable, suggesting that market sentiment toward U.S. dollar assets could weaken significantly.

The paper sheds light on the attractiveness for U.S. assets by studying dollar risk premiums and linking them to bilateral capital flows. First, bilateral risk premiums on the U.S. dollar are estimated, using an uncovered interest parity framework and Consensus exchange rate forecasts. Second, the paper analyzes the link between capital flows and measured risk premiums for various regions. Finally, the paper uses regression analysis to test whether macroeconomic factors have had an influence on movements in risk premiums.

Risk premiums were estimated at one-and two-year horizons for the dollar against the pound sterling, the Canadian dollar, the euro, and the yen. These series were also used to construct "global" dollar risk premium measures.

\section{Results}

Dollar risk premiums have generally been negative in recent years. ${ }^{12}$ This is consistent with investors buying U.S. assets for reasons other than expected returns, such as the presence of a wider range of financial instruments, or liquidity or security preferences. However, premiums have exhibited large fluctuations against the Japanese yen and the euro:

- The risk premium vis-à-vis the euro declined to about -10 percent in 2000, but has now moved closer to zero.

- $\quad$ The risk premium against the yen has generally been positive, but turned negative in recent years - consistent with studies that find Japanese home bias declining from extremely high levels in the past.

- $\quad$ The overall risk premium has largely remained negative in recent years. Rising expectations of dollar depreciation have only been partly offset by growing interest differentials in favor of the United States.

\footnotetext{
${ }^{12}$ For the purpose of this paper, a dollar risk premium is defined as the difference in one or two-year interest rates on U.S. and foreign assets, adjusted for expected changes in the exchange rate. A negative premium implies that investors accept a negative expected return by investing in U.S. interest-bearing assets.
} 
These trends coincided with a substantial increase in capital flows into the United States in recent years. The rise in U.S. net liabilities has occurred mostly through increases in fixed income securities, which were purchased largely by investors in the euro area, Japan, and emerging Asian economies. European investors acquired mainly corporate bonds and equity, whereas Japan and emerging Asia invested primarily into treasury bonds. The coincidence of riskier investment patterns and - on occasion - strongly negative risk premiums on the dollar against the euro suggests that European investors may have had a greater risk appetite than Asian investors as far as U.S. assets have been concerned.

Fluctuations in dollar sentiment seem to be largely unrelated to macroeconomic developments. Regressions of risk premiums on variables such as debt sustainability indicators and U.S.-foreign growth differentials generally yielded incorrectly signed or insignificant coefficients.

On the other hand, differences in regional risk appetites, and the aftermath of the Asia crisis, appear to have had a measurable influence on dollar sentiment. In particular, an increase in risk appetites in the U.K. and the euro area - as measured by investors' revealed preference for purchasing corporate bonds over safer Treasury assets - tends to go hand in hand with a decline in risk premiums on the dollar.

\section{Policy implications}

The constellation of negative risk premiums and record capital inflows could suggest that investors may favor U.S. investments for structural reasons. The paper found that measures that influence expected returns - such as relative growth prospects - appear to have not been particularly important. One possible explanation could be that the Asian crisis created a large pool of savings searching for low-risk investment opportunities, which were provided by relatively deep, liquid, and innovative U.S. financial markets. Moreover, continued inflows of European funds into the United States suggest that investors are attracted by the wide array of instruments with different risk/return characteristics that only U.S. markets currently offer.

Looking forward, the allocative efficiency of U.S financial markets could mitigate the risks of a disorderly unwinding of global current account imbalances. To be sure, there is the risk that foreign investors will begin to demand a sharp increase in relative compensation for dollar assets without a rapid dollar depreciation. However, the likelihood of such an adverse scenario is reduced by the dollar's role as global reserve currency; the recent improvement in economic prospects in other regions; and by the continued attractiveness of the U.S. financial system, assuming that continued innovation retains its advantage over other financial markets. 


\section{How Might a Disorderly Resolution of Global Imbalances Affect Global Wealth? by Francis E. Warnock (WP/06/170)}

The widening U.S. current account deficit and the associated large positions that foreigners have amassed in U.S. securities have garnered much attention. This paper addresses the question how a disorderly adjustment that involves a marked shift in investor preferences away from U.S. assets might impact the wealth of residents in a wide range of foreign countries. To provide a sense of the orders of magnitude involved, a stylized scenario is analyzed in which there is a simultaneous decline in the value of the dollar against all other currencies, accompanied by a fall in U.S. bond and equity prices.

Very similar results are found using two surveys of international investment positions with different strengths and weaknesses:

- $\quad$ The comprehensive U.S. benchmark liabilities survey is of extremely high quality, but liabilities are subject to a custodial center bias from the use of third-country custodians. If, for example, a German resident holds a U.S. corporate bond through a custodian in Luxembourg, the survey will attribute the holdings to Luxembourg. The survey can only access the first foreign address, not that of the ultimate holder.

- The IMF's December 2004 Coordinated Portfolio Investment Survey (CPIS) does not yet have the same level of overall quality, since many of the participants are still refining their survey techniques. However, as it compiles results from individual country's asset surveys, it suffers less from the custodial center bias.

A disorderly adjustment is illustrated by assuming a simultaneous 10 percent decline in the U.S. currency and prices in equity and bond markets. The combination of all three markets moving in the same direction is indicative of a shift in investor preferences. However, the calculations are based on the assumption that the scenario would impact U.S. markets only, which may be regarded as somewhat unlikely.

The impact would be to lower the rest of the world's wealth by about 5 percentage points of GDP. In aggregate, foreigners have accumulated large positions in U.S. bonds and equitiesroughly $\$ 5$ trillion by mid-2004 - with considerable variation in exposure across countries. The analysis suggests that for every 10 percent drop in U.S. bond prices and in the exchange value of the dollar, aggregate wealth losses for the rest of the world would amount to $2 \frac{1}{2}$ percentage points of their GDP. If, in addition, U.S. equity markets also declined by 10 percent, foreigners would incur losses of another $1 \frac{1}{2}$ percentage points of GDP. Including losses through the rest of the world's exposure to dollar-denominated bonds issued by foreign countries, brings the total loss to nearly 5 percentage points of GDP.

These losses are about half as large as those experienced by U.S. residents. A 10 percent decrease in U.S. equity and bond markets would lead to a decrease in U.S. wealth of almost 
11 percentage points of GDP. Partially offsetting this would be the 2 percentage point gain from the currency appreciation on U.S. investors' foreign portfolio holdings.

The exposure of the rest of the world to U.S. assets has increased rapidly over time, reflecting rapid internationalization of asset markets as well as large U.S. external deficits. Aggregate losses from U.S. assets based on the disorderly scenario discussed above would have been 1 percentage point of foreign GDP in 1994, 3 percentage points in 2000, and 4 percentage points as of 2004. Examining the impact across more than 50 countries illustrates that the increased exposure to U.S. securities markets over the past decade has been broadly based.

The exposure to U.S. assets is similar for developed countries and for emerging markets, but for emerging markets reserve holdings are more important. Foreign countries, and especially emerging markets, are more exposed to U.S. bonds than to U.S. equities. While the average overall exposure of developed countries and emerging markets is very similar (when normalized by GDP), the exposure of the public sector is much larger for emerging markets. The analysis of reserves positions suggests that public sector losses in emerging markets could amount to about $23 / 4$ percentage points of GDP.

Exposures vary significantly across individual countries. Excluding financial centers where losses are artificially high due to large custodial bias (Belgium, Hong Kong, Luxembourg, Singapore, and parts of the Caribbean), countries with high losses include Ireland (14 $1 / 2$ percent of GDP), Taiwan and the Netherlands ( 8 percent), Canada, Norway, Sweden, and the United Kingdom (5-6 percent), and China, Japan, and Middle East oil exporters (4-41/2 percent). These countries could also incur additional losses through custodial centers.

\section{Policy implications}

Rapidly growing holdings of foreign assets have increased the potential for international wealth spillovers. While global wealth effects from a significant depreciation in the dollar and fall in the value of U.S. asset prices were trivial as late as of the mid-1990s, these effects have quadrupled and become systemically important. As a result, the impact of a sudden adverse shock to U.S. asset prices on foreign wealth could be as large as half the impact on U.S. wealth (relative to foreign and U.S. GDP, respectively).

The similarity of the exposures of emerging markets and developed countries underlines growing links within the international monetary system. Emerging Asia and, more recently, oil exporters have become important sources of capital inflows to the United States. One important difference, however, is that for emerging markets most of the losses would be experienced by governments, while in the developed world the impact would be primarily on the private sector. 


\section{Moving to Territoriality? Implications for the United States and the Rest of the World \\ by Peter Mullins (WP/06/161)}

The Report of President's Advisory Panel on Federal Tax Reform includes a suggestion to move the corporation tax from its present worldwide basis to a territorial basis. Under the worldwide tax system, profits earned abroad are taxed in the United States when they are repatriated, but with a credit for foreign taxes paid. Under the territorial tax system, profits earned abroad would be exempt in the United States. The paper considers the implications of such a reform for the United States and the rest of the world.

\section{Impact on the United States}

Advocates of territorial taxation argue that it would increase the competitiveness of U.S. firms in foreign markets. This is because foreign earnings of U.S. firms would not be taxed at U.S. corporate rates, which are relatively high by international comparison. Other arguments used to support territoriality include: removing a distortionary incentive to retain profits offshore, which could increase domestic investment; eliminating some avoidance opportunities; and greater simplicity.

Opponents argue that territoriality will encourage U.S. firms to invest abroad rather than in the United States. In their view, the gains from simplification would be minimal, as many of the current complex rules would still apply under a territorial system, and some existing problems (such as transfer pricing) would be exacerbated.

The potential benefits to the United States from adopting a territorial system are not clear cut. Against this background, there may be merit in an often proposed alternative that would retain the worldwide system but remove the current deferral of tax until repatriation (and hence the bias against this behavior) and tightening foreign tax crediting rules.

\section{Impact on the foreign countries}

The rest of the world's interest in a move by the United States to a territorial system would partly depend on its impact on U.S. FDI abroad. The United States is the leading source of FDI, accounting for around 20 percent of the worldwide stock, and relatively small changes could have a large impact on some other countries. Recipient countries would benefit to the extent that increased U.S. FDI inflows would not displace FDI from elsewhere, leading to a net gain in revenue.

The impact on foreign tax revenues is potentially sizable. The amount of revenue at stake is significant as foreign taxes paid by U.S. companies on foreign source income amounted to $\$ 44 \frac{1}{2}$ billion in 2001 , of which about a third accrued to developing countries. 
In considering the implications for the rest of the world, the paper addresses three key questions:

- Would the territorial system change the level and location of U.S. FDI? The empirical evidence suggests that a U.S. move to a territorial system could lead to changes in the location of FDI (in response to differences in national tax rates) but would leave the overall level of U.S. FDI roughly unchanged. This result reflects a number of factors, including the impact of other tax changes associated with the move to a territorial system - such as limits on expense deductibility and foreign tax crosscrediting; the tax exemption already provided under the current system (largely through tax deferral); and the possibility that increased U.S. FDI would replace nonU.S. FDI.

- Would the territorial system encourage tax competition to attract U.S. FDI? To the extent that countries are already competing to attract investment from other countries with territorial systems, the additional impact on tax competition may be limited. However, some countries that are currently setting tax rates to "soak up" U.S. foreign tax credits may move to a territorial system, which could encourage others to reduce rates to attract more FDI.

- Would other countries follow the United States lead and move to a territorial system? Except in the Latin American region, many emerging markets and developing countries have generally shifted toward territorial taxation, and adoption by the United States could provide further encouragement in this direction. However, given the scope for abuse under a territorial system (e.g., related to transfer pricing), the revenue impact could be negative for countries without strong administrative systems in place. Moreover, most double tax treaties provide for taxes on multinational corporations to be collected by the source country. Therefore, U.S. treaty partners may feel under pressure to reduce their tax rates in order to attract U.S. FDI.

\section{Policy implications}

A move to territoriality may have tax revenue implications for the United States. The direct effect of exempting foreign source income would be to reduce tax revenues, although the Tax Panel and other analysts argue that the proposal would be largely revenue-neutral or even increase revenues. This is due to the possible increase in investment in the United States as a result of earlier profit repatriation, as well as the effect of other proposed tax changes associated with the territorial system.

A move by the United States could also intensify tax competition amongst developing countries. Although countries already competing for FDI from other destinations would be less affected, countries where U.S. FDI has traditionally been most important could experience additional pressures on revenues. 


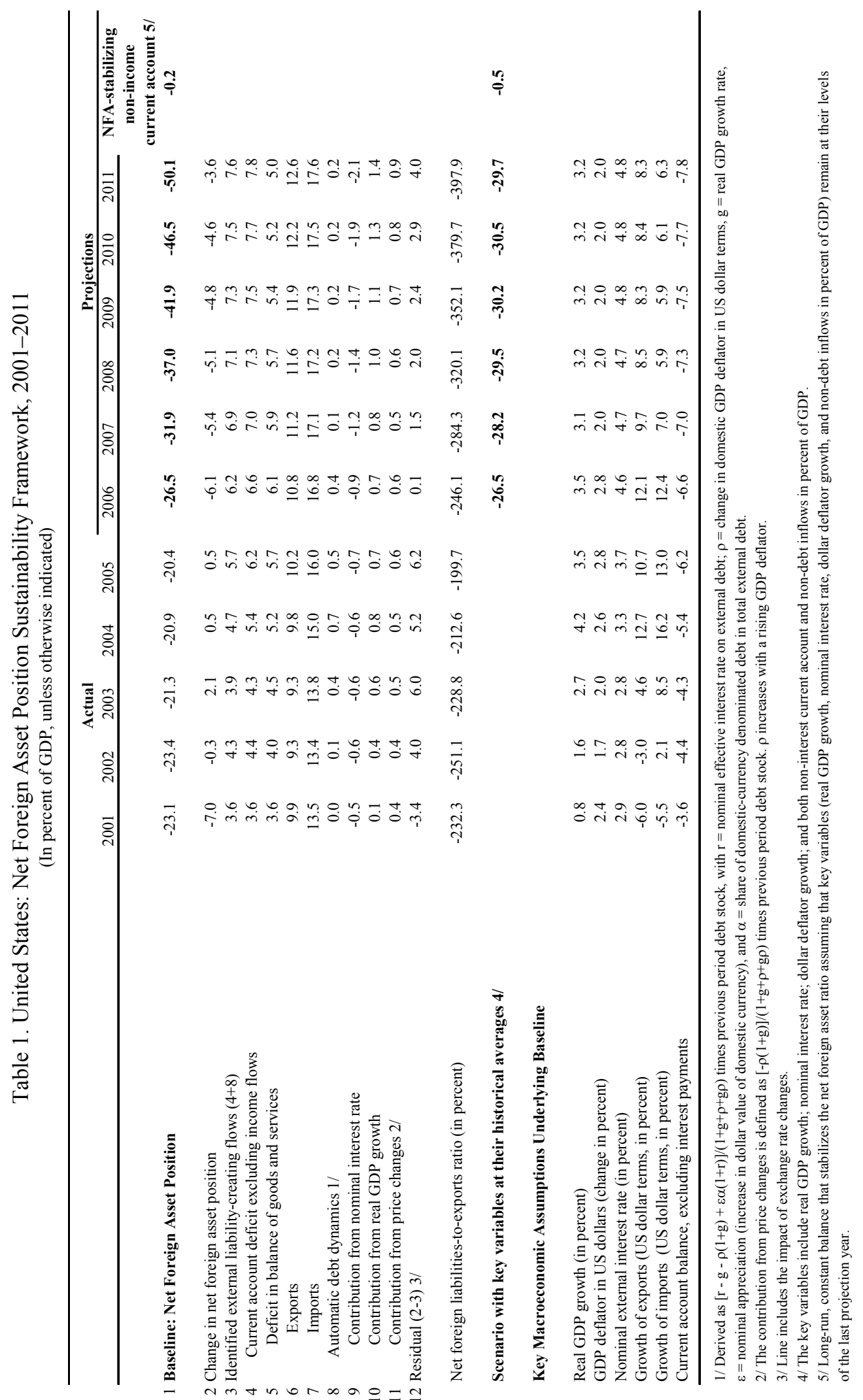




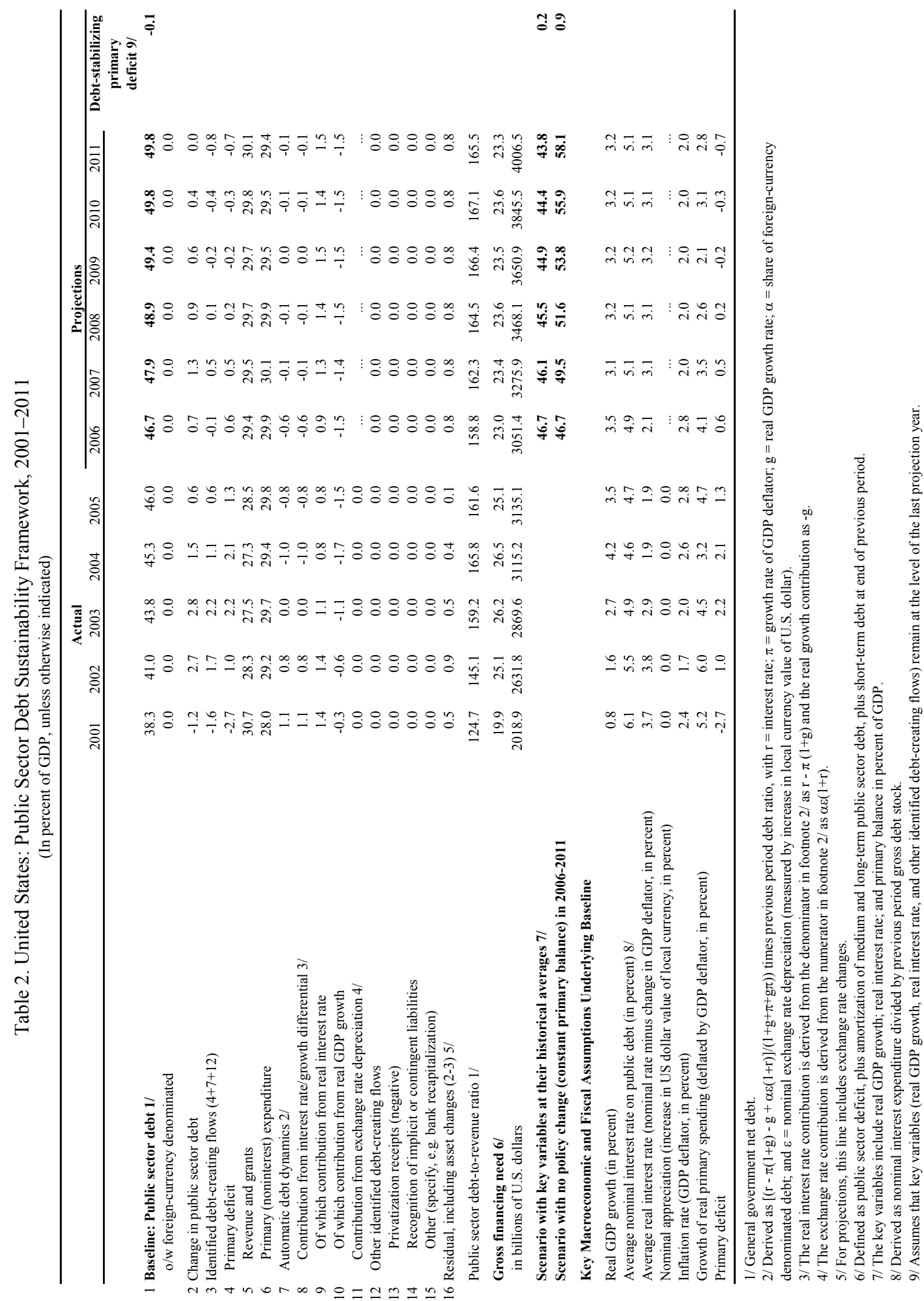


Figure 1. United States: Net Foreign Asset Sustainability: Bound Tests 1/

(Net foreign assets in percent of GDP)
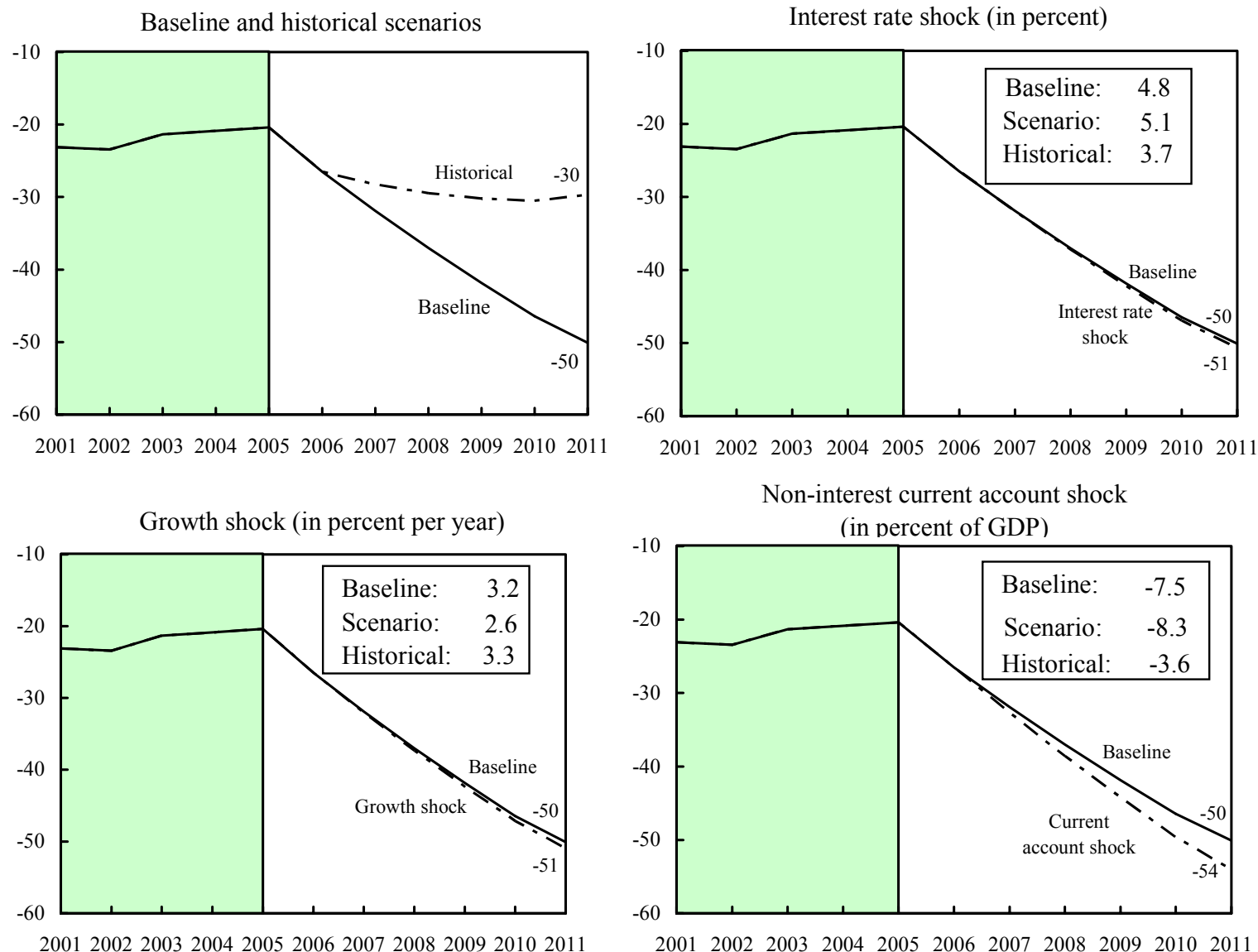

20012002200320042005200620072008200920102011

20012002200320042005200620072008200920102011

Combined shock 2/
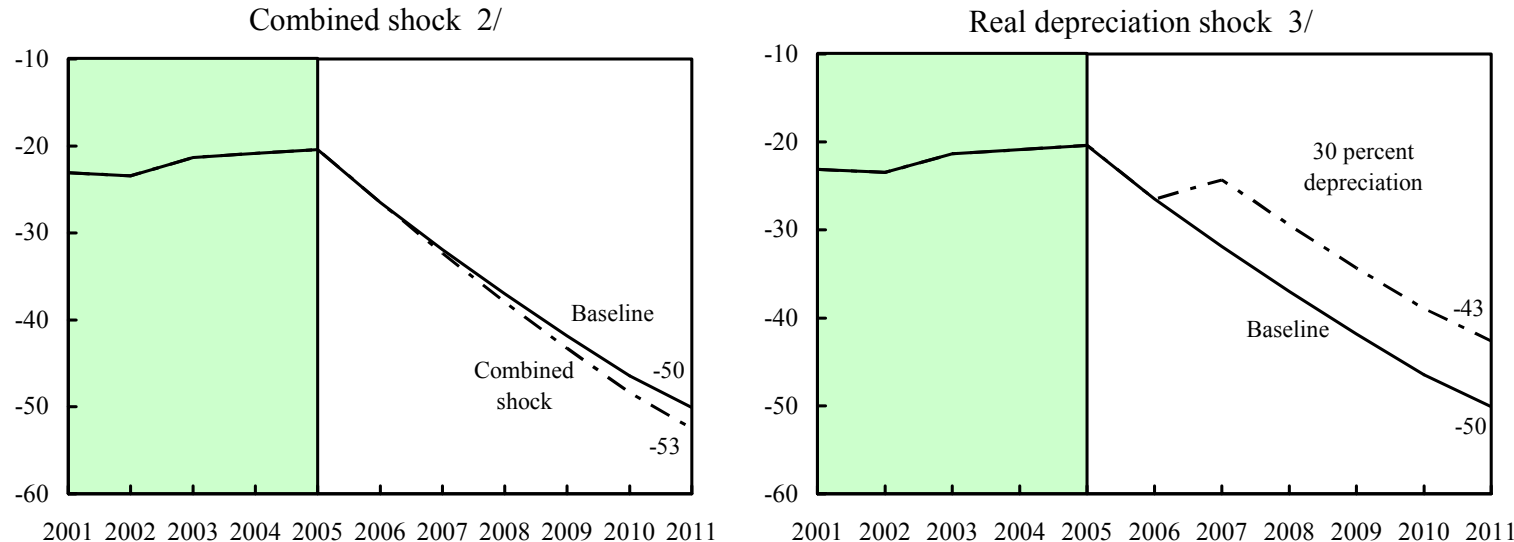

20012002200320042005200620072008200920102011

Source: Fund staff estimates.

1/ Shaded areas represent actual data. Individual shocks are permanent one-half standard deviation shocks.

Figures in the boxes represent average projections for the respective variables in the baseline and scenario being presented. Ten-year historical average for the variable is also shown.

2/ Permanent 1/4 standard deviation shocks applied to real interest rate, growth rate, and current account balance.

3/ One-time real depreciation of 30 percent occurs in 2007. 
Figure 2. United States: Public Debt Sustainability: Bound Tests 1/

(Public debt in percent of GDP)

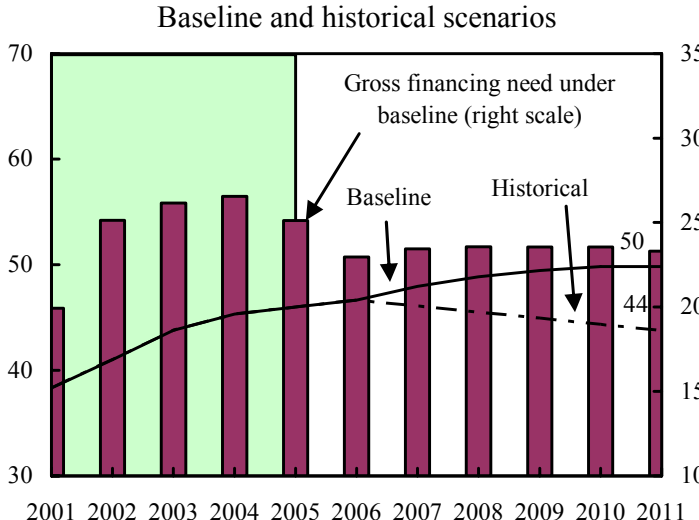

Growth shock (in percent per year)

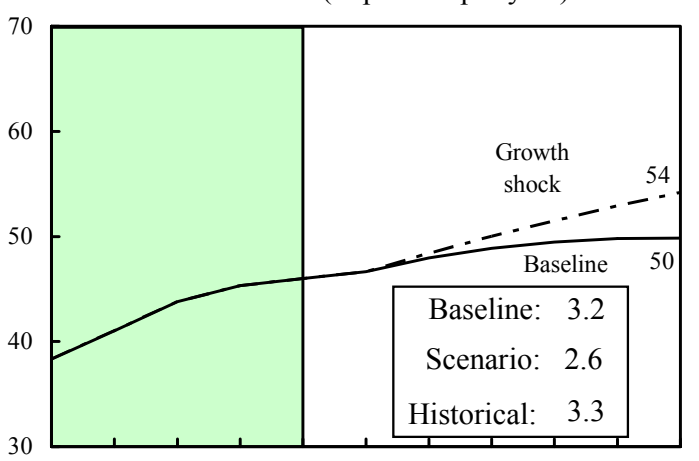

20012002200320042005200620072008200920102011

Combined shock 2/

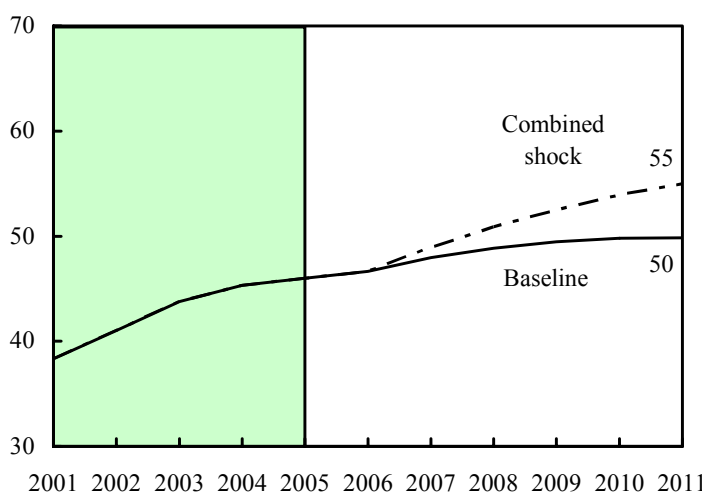

Real interest rate shock (in percent)

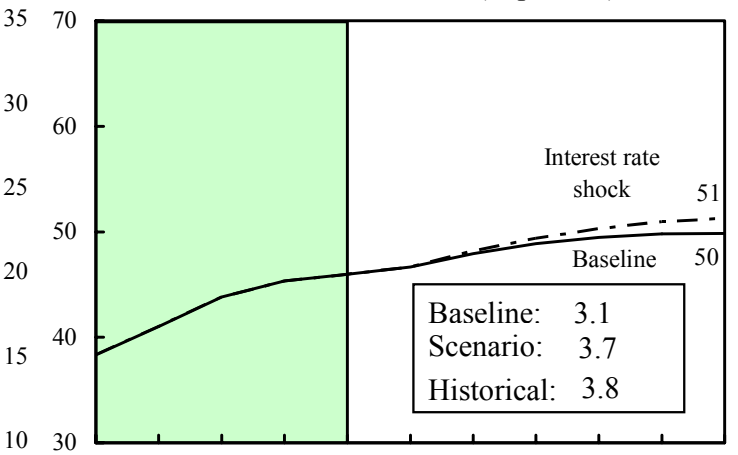

20012002200320042005200620072008200920102011

Primary balance shock (in percent of GDP) and no policy change scenario (constant primary balance)

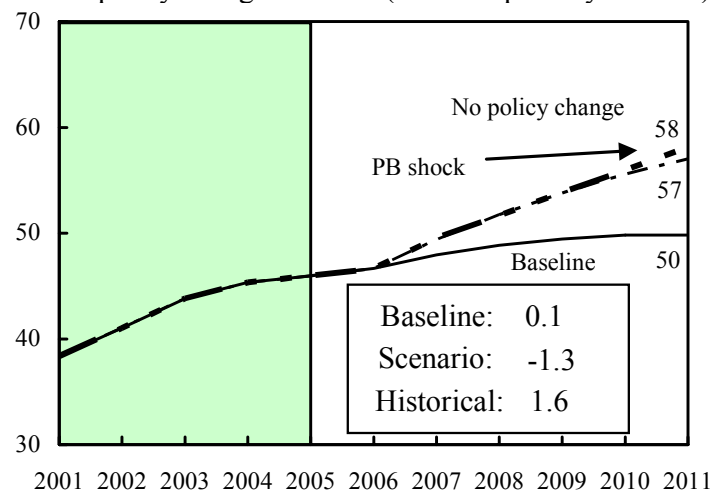

Real depreciation and contingent liabilities shocks $3 /$

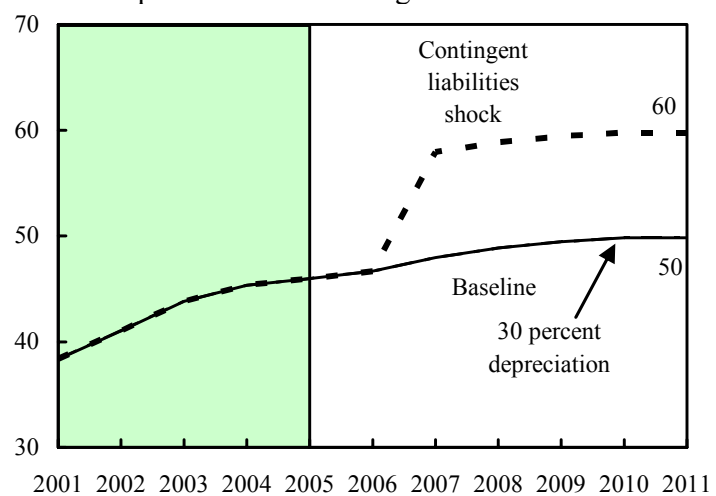

Source: Fund staff estimates.

1/ Shaded areas represent actual data.Individual shocks are permanent one-half standard deviation shocks.

Figures in the boxes represent average projections for the respective variables in the baseline and scenario being presented. Ten-year historical average for the variable is also shown.

2/ Permanent 1/4 standard deviation shocks applied to real interest rate, growth rate, and primary balance.

3/ One-time real depreciation of 30 percent and 10 percent of GDP shock to contingent liabilities occur in 2006, with real depreciation defined as nominal depreciation (measured by percentage fall in dollar value of local currency) minus domestic inflation (based on GDP deflator). 


\section{United States: Fund Relations}

(As of May 31, 2006)

I. Membership Status: Joined 12/27/45; Article VIII

II. General Resources Account:

Quota

Fund holdings of currency

Reserve position in Fund

III. SDR Department:

Net cumulative allocation

Holdings
SDR Million

$37,149.30$

$32,727.88$

$4,419.44$

SDR Million

$4,899.53$

$5,825.20$
Percent

Quota

100.0

88.1

11.9

Percent

Allocation

100.0

118.9

IV. Outstanding Purchases and Loans: None

V. Financial Arrangements: None

VI. Projected Obligations to Fund: None

VII. Exchange Rate Arrangements: The exchange rate of the U.S. dollar floats independently and is determined freely in the foreign exchange market.

VIII. Payments Restrictions: The United States maintains restrictions on payments and transfers for current international transactions to the Balkans, Belarus, Cote d'Ivoire, Cuba, Democratic People's Republic of Korea, Iraq, Islamic Republic of Iran, Liberia, Myanmar, Sudan, Syrian Arab Republic, and Zimbabwe and has notified the Fund of these restrictions under Decision No. 144-(52/51). The United States restricts the sale of arms and petroleum to the National Union for the Total Independence of Angola (UNITA) and to the territory of Angola and has prohibitions against transactions with international narcotics traffickers. The United States notified the Fund under Decision No. 144-(52/51) on August 2, 1995 of the imposition of further restrictions on current transactions with Islamic Republic of Iran. On March 21, 2002, the United States notified the Fund of exchange restrictions related to the financing of terrorism. The United States has lifted restrictions previously imposed with respect to Libya.

IX. Article IV. The 2005 Article IV consultation was concluded in July 2005 and the Staff Report was published as IMF Country Report 05/245. A fiscal ROSC was completed in the context of the 2003 consultation. 


\section{Statistical Issues}

Statistical Issues: Comprehensive economic data are available for the United States on a timely basis. The quality, coverage, periodicity, and timeliness of U.S. economic data are considered to be good both in the context of the Article IV consultation and for purposes of ongoing surveillance. The United States has subscribed to the Special Data Dissemination Standard (SDDS) and its metadata are posted on the Dissemination Standard Bulletin Board (DSBB).

\section{United States: Table of Common Indicators Required for Surveillance}

(As of June 23, 2006)

\begin{tabular}{|c|c|c|c|c|c|}
\hline & $\begin{array}{c}\text { Date of latest } \\
\text { observation }\end{array}$ & $\begin{array}{l}\text { Date } \\
\text { received }\end{array}$ & $\begin{array}{l}\text { Frequency } \\
\text { of data }^{6}\end{array}$ & $\begin{array}{l}\text { Frequency of } \\
\text { reporting }\end{array}$ & $\begin{array}{c}\text { Frequency of } \\
\text { publication }^{6}\end{array}$ \\
\hline Exchange rates & same day & same day & $\mathrm{D}$ & $\mathrm{D}$ & $\mathrm{D}$ \\
\hline $\begin{array}{l}\text { International reserve assets and reserve } \\
\text { liabilities of the monetary authorities }{ }^{1}\end{array}$ & Jun. 16 & Jun. 20 & $\mathrm{~W}$ & $\mathrm{~W}$ & $\mathrm{~W}$ \\
\hline Reserve/base money & Jun. 21 & Jun. 22 & $\mathrm{~B}$ & W & $\mathrm{W}$ \\
\hline Broad money & May 2006 & Jun. 15 & M & $\mathrm{W}$ & $\mathrm{W}$ \\
\hline Central bank balance sheet & Mar. 31, 2006 & Jun. 8 & Q & Q & Q \\
\hline Interest rates $^{2}$ & Same day & Same day & $\mathrm{D}$ & $\mathrm{D}$ & $\mathrm{D}$ \\
\hline Consumer price index & May 2006 & Jun. 14 & M & M & M \\
\hline $\begin{array}{l}\text { Revenue, expenditure, balance and } \\
\text { composition of financing }{ }^{3}-\text { general } \\
\text { government }\end{array}$ & 2006 Q1 & Apr. 28 & Q & Q & Q \\
\hline $\begin{array}{l}\text { Revenue, expenditure, balance and } \\
\text { composition of financing }{ }^{3}-\text { central } \\
\text { government }\end{array}$ & May 2006 & Jun. 12 & M & M & M \\
\hline $\begin{array}{l}\text { Stocks of central government and central } \\
\text { government-guaranteed debt }\end{array}$ & May 2006 & Jun. 6 & M & M & M \\
\hline External current account balance & 2006 Q1 & Jun. 16 & Q & Q & Q \\
\hline Exports and imports of goods and services & Apr. 2006 & Jun. 9 & $\mathrm{M}$ & $\mathrm{M}$ & $\mathrm{M}$ \\
\hline GDP/GNP & 2006 Q1 & Apr. 28 & Q & Q & Q \\
\hline Gross External Debt ${ }^{5}$ & Mar. 31, 2006 & Jun. 8 & Q & Q & Q \\
\hline
\end{tabular}

\footnotetext{
${ }^{1}$ Includes reserve assets pledged or otherwise encumbered as well as net derivative positions.

${ }^{2}$ Both market-based and officially-determined, including discount rates, money market rates, rates on treasury bills, notes and bonds.

${ }^{3}$ Foreign, domestic bank, and domestic nonbank financing.

${ }^{4}$ The general government consists of the central government (budgetary funds, extra budgetary funds, and social security funds) and state and local governments.

${ }^{5}$ Including currency and maturity composition.

${ }^{6}$ Daily (D), Weekly(W), Biweekly(B), Monthly(M), Quarterly (Q), Annually (A); NA: Not Available.
} 


\section{Statement by the IMF Staff Representative}

July 24, 2006

\section{This note reports on information that has become available since the staff report} was issued. The topics covered include the recent economic and financial market developments, monetary policy prospects, and the budget outlook. They do not affect the staff appraisal.

\section{Recent economic and financial market developments}

2. Recent developments continue to point to a gradual slowing in activity. June payroll employment rose by only 121,000 , but with stronger growth in the household employment survey, the unemployment rate remained steady at 4.6 percent. Indicators continue to suggest that the housing market is cooling, with weaker housing starts and building permits in June. Retail sales retreated 0.1 percent and producer and consumer sentiment have both softened. However, industrial production increased 0.8 percent in June, and relatively strong export growth helped keep the trade deficit broadly stable at $\$ 63.8$ billion in May, suggesting an upside risk to the staff's estimate of real net exports.

3. Core CPI inflation again exceeded expectations in June. The 12-month increase in overall and core consumer prices ticked up to 4.3 percent and 2.6 percent, respectively, with the increase in core inflation slightly above market expectations. While 12-month core producer price inflation was stable and in line with expectations at 1.9 percent, headline PPI inflation rose to 4.8 percent and hourly wage growth accelerated to close to 4 percent in June. However, spreads between conventional and inflation-indexed 10-year bonds remained stable at around 2.6 percent, suggesting that inflation expectations remain relatively well anchored.

4. U.S. financial markets have softened in response to signs of slowing activity. Longterm bond yields have decreased by about 10 basis points to just over 5 percent and equity prices have fallen by $1 \frac{1}{2}$ to 2 percent since end-June. Market expectations regarding the nearterm course of monetary policy have remained broadly unchanged, with futures prices suggesting a roughly 50 percent probability of a 25 basis point hike in the federal funds rate at the early August meeting of the Federal Open Markets Committee.

\section{Monetary and fiscal developments}

5. The Federal Reserve's semi-annual Monetary Policy Report (MPR) was presented to Congress on July 19 by Chairman Bernanke. The MPR projects that core PCE inflation (which has been running around a $1 / 4$ percentage point lower than core CPI inflation) will likely ease from around 21/4-21/2 percent in 2006 (fourth quarter on fourth quarter) to slightly above 2 percent in 2007. Economic growth is projected to moderate from around 31/4-31/2 percent this year (again fourth quarter on fourth quarter) to around 3-31/4 percent in 2007. Both forecasts are broadly in line with staff projections. The Chairman acknowledged the 
recent rise in core inflation but appeared confident that, with growth slowing, inflation would ease later in the year, prompting markets to rally.

\section{The Administration's Mid-Session Review sharply lowered the forecast budget} deficit for this year to a level consistent with staff projections. Reflecting buoyant and broad-based revenue growth through June, the Administration lowered its projection for the FY 2006 unified federal deficit (ends this September 30) to \$296 billion (21/4 percent of GDP), from its February estimate of $\$ 423$ billion (31/4 percent of GDP), leaving the forecast identical to the staff's. The strong revenue growth, together with expectations of further compression in the expenditure ratio beyond FY 2008 owing to higher growth, have also led the Administration to reduce projected deficits for FY2007-11 by $1 / 4-1 / 2$ percent of GDP (Table), with the unified federal deficit projected to fall below 1 percent of GDP by FY 2010.

\section{The Mid-Session Review emphasized the need to address the long-term fiscal} challenge posed by the unsustainable growth in entitlement spending. It noted that “...entitlement spending in Social Security, Medicare, and Medicaid is growing faster than the economy and the Nation's ability to pay for this spending. No plausible amount of cuts to discretionary programs or tax increases can avert this major fiscal challenge," underscoring the urgent need for entitlement reform.

\section{United States: Unified Budget}

\begin{tabular}{|c|c|c|c|c|c|c|c|}
\hline & FY 2005 & FY 2006 & FY 2007 & FY 2008 & FY 2009 & FY 2010 & FY 2011 \\
\hline \multicolumn{8}{|l|}{ FY 2007 Mid-Session Review ${ }^{1}$} \\
\hline Outlays & 20.1 & 20.6 & 20.1 & 19.4 & 18.9 & 18.7 & 18.8 \\
\hline Net interest expense & 1.5 & 1.7 & 1.8 & 1.8 & 1.8 & 1.8 & 1.8 \\
\hline Revenue & 17.5 & 18.3 & 17.7 & 18.1 & 17.9 & 18.0 & 18.1 \\
\hline Unified balance & -2.6 & -2.3 & -2.4 & -1.3 & -1.0 & -0.8 & -0.7 \\
\hline \multicolumn{8}{|l|}{ FY 2007 Budget } \\
\hline Outlays & 20.1 & 20.8 & 20.1 & 19.4 & 19.1 & 19.0 & 19.1 \\
\hline Net interest expense & 1.5 & 1.7 & 1.8 & 1.9 & 1.9 & 1.9 & 1.9 \\
\hline Revenue & 17.5 & 17.5 & 17.6 & 17.8 & 17.7 & 17.9 & 17.9 \\
\hline Unified balance & -2.6 & -3.3 & -2.6 & -1.5 & -1.4 & -1.1 & -1.2 \\
\hline \multicolumn{8}{|l|}{ Differences } \\
\hline Outlays & & -0.2 & 0.0 & 0.0 & -0.2 & -0.3 & -0.3 \\
\hline Net interest expense & & 0.0 & 0.0 & -0.1 & -0.1 & -0.1 & -0.1 \\
\hline Revenue & & 0.8 & 0.1 & 0.3 & 0.2 & 0.1 & 0.2 \\
\hline Unified balance & & 1.1 & 0.2 & 0.2 & 0.4 & 0.3 & 0.5 \\
\hline \multicolumn{8}{|l|}{ Staff Forecast } \\
\hline Unified Balance & & -2.3 & -2.6 & -2.3 & -2.0 & -1.9 & -1.8 \\
\hline Difference from Mid-Session Review & & 0.0 & -0.2 & -1.0 & -1.0 & -1.1 & -1.1 \\
\hline
\end{tabular}




\section{IMF Executive Board Concludes 2006 Article IV Consultation with the United States}

On July 24, 2006, the Executive Board of the International Monetary Fund (IMF) concluded the Article IV consultation with the United States. ${ }^{1}$

\section{Background}

The U.S. economy continued to grow strongly over the last year even in the face of a withdrawal of monetary stimulus and high oil prices. Household spending remained the principal driver of the expansion, spurred by mortgage borrowing and double-digit house price inflation. However, employment and wage growth remained modest, and the household saving ratio moved further into negative territory. As a result, and despite strong business saving and an improvement in the fiscal balance, the current account deficit reached a new record high.

Household consumption and residential investment have grown an average $1 / 2$ percentage point faster than GDP since the 2001 recession, financed in large part through home equity withdrawal, stimulated by rapid house price inflation as well as innovative mortgage instruments, low refinancing costs, and easy access to tax-advantaged home equity loans. However, U.S. house prices now appear to be overvalued and with signs that market conditions are cooling, the housing market is no longer likely to provide significant support to household spending.

\footnotetext{
${ }^{1}$ Under Article IV of the IMF's Articles of Agreement, the IMF holds bilateral discussions with members, usually every year. A staff team visits the country, collects economic and financial information, and discusses with officials the country's economic developments and policies. On return to headquarters, the staff prepares a report, which forms the basis for discussion by the Executive Board. At the conclusion of the discussion, the Managing Director, as Chairman of the Board, summarizes the views of Executive Directors, and this summary is transmitted to the country's authorities.
} 
During the past year, business investment also remained robust, supported by declines in capital goods prices, the economic expansion, and high profits, even in the face of higher interest rates. U.S. businesses have generally used high profits and low interest rates to strengthen balance sheets and accumulate cash holding, suggesting that the fundamentals for investment remain strong.

With sustained strong growth and recent hikes in oil and commodity prices, resource utilization has increased and headline inflation remained high. Although core CPI inflation had been relatively subdued, in recent months the core rate has risen sharply, exceeding $21 / 2$ percent in June (12-month rate). At the same time, the unemployment rate-at just above $4 \frac{1}{2}$ percent in June-remains at the low end of most estimates of the NAIRU, and capacity utilization reached its long-run average. Nevertheless, unit labor costs have remained contained, reflecting solid productivity growth and modest wage gains.

The current account deficit has widened on higher oil prices and solid import demand, and stood at about $61 / 2$ percent of GDP in the first quarter of 2006. Nevertheless, the dollar remained broadly stable, and the U.S. net foreign liability position barely deteriorated in 2005 , reflecting the valuation effects of the relative strength of foreign equity markets.

U.S. financial markets have provided important support to the expansion and facilitated the U.S. economy's ability to access foreign saving. Financial market innovation-including securitization and credit risk transfer techniques-contributed to low credit risk spreads and improved the pricing and allocation of credit risk. The increased activity of hedge funds has enhanced price discovery and liquidity in many of the new markets. At the same time, banks remained wellcapitalized and highly profitable despite changing market conditions. While bank revenues continued to depend on the real estate market, widespread securitization has helped reduce vulnerabilities to regional shocks, and a range of indicators suggest that systemic risks are at a low ebb.

Against this background, the Federal Reserve Board continued to gradually withdraw monetary stimulus, raising the federal funds rate to 5 percent by the time of the Article IV discussions and further to 51/4 percent after the June 28-29 meeting of the Federal Market Open Committee (FOMC). On the fiscal front, federal tax revenues remained buoyant and expenditure discipline has been maintained, suggesting that the FY 2006 federal budget deficit is likely to outperform initial budget estimates and fall modestly to $2 \frac{1}{4}$ percent of GDP. Looking forward, the Administration appears on track for achieving its goal of halving the federal budget deficit earlier than FY 2009.

The staff's baseline scenario for the short-term outlook is for a "soft landing," with growth easing to potential and inflation remaining contained. The housing market is likely to cool in response to high valuations and tightening financial conditions, reducing the impetus from consumption and residential investment, but strong fundamentals should continue to support business investment. The external deficit is likely to remain wide, but the drag on activity from net exports will lessen as growth abroad strengthens. On the supply side, solid productivity growth should accommodate wage gains while containing price pressures. 
There appear to be competing risks to this outlook. The possibility of a more abrupt slowdown in the housing market, disappointments on the productivity front, and a disorderly adjustment to global imbalances, as well as the risk of higher oil prices more than offset the upside potential for business investment. Avian flu and geopolitical events represent further and more difficult to quantify downside risks. In contrast, inflation risks-which mainly stem from supply effectsseem mostly on the upside. These include the possibility of a larger-than-anticipated productivity slowdown pushing up unit labor costs, and the potential for pass-through of high commodity and oil prices.

\section{Executive Board Assessment}

Executive Directors agreed with the thrust of the staff appraisal. They noted that-despite a significant withdrawal of monetary stimulus, high energy prices, and other shocks-the U.S. economy continues to be a key engine of global growth, supported by strong productivity increases. Encouragingly, buoyant tax revenues are likely to keep the FY 2006 federal deficit well below initial budget estimates. Also, Directors commended the Federal Reserve for the measured pace of its monetary tightening which, accompanied by a clear communications policy, has helped keep inflationary expectations in check while avoiding a pronounced slowdown in activity.

Looking forward, Directors saw good prospects for a soft landing of the economy, with growth likely to ease to a more sustainable rate and inflation to remain contained. However, most Directors cautioned that risks to activity are on the downside, reflecting a cooling housing market, higher energy prices, and a negative household saving rate. At the same time, these Directors observed that the recent pick up in core inflation and expectations, coupled with a further drop in the unemployment rate, suggests a risk of a build up in price pressures.

Given these competing risks, Directors observed that the Federal Reserve will need to steer an especially delicate course that limits downside risks to activity while ensuring that inflation expectations remain anchored. In such circumstances, future policy decisions would depend heavily on evolving views on the outlook as well as the importance of ensuring that inflation expectations are kept in check.

Directors remarked that the Fed's communications strategy in recent years has been highly effective. Nonetheless, a number of Directors suggested that there could be merit in the Fed providing a more explicit statement of its inflation objective, noting that this could help further anchor inflation expectations without undermining confidence in the Fed's commitment to its broader mandate. In this context, some Directors remarked that a formal inflation target might bring little additional gain to the Fed's well-established credibility, while having implications for the Fed's other policy objectives. Directors looked forward to a further consideration of these issues, and welcomed the recent establishment of a committee to examine the Fed's overall communication policy, including refining the definition of price stability. Some Directors also observed that providing more frequent Monetary Policy Reports with a greater focus on future developments could further increase the Fed's high level of transparency. 
Directors recognized that the U.S. financial sector has proven innovative and resilient in recent years, and noted that the financial system appears well-positioned as the credit cycle turns. At the same time, Directors saw important areas where further reform could help enhance the financial system's resilience and efficiency. These included tightening the supervision of the housing Government Sponsored Enterprises (GSEs), reforming rules for defined-benefit pension plan, and possibly moving to consolidate supervision and regulation of insurance companies. Directors welcomed the authorities' willingness to undertake an IMF Financial Sector Assessment Program, which they considered could provide further insights on these challenges, as well as a good framework for further analysis of the systemic role of the U.S. financial markets. It would be similarly beneficial to publish a regular Financial Stability Report.

Directors cautioned that demographic and other pressures continue to threaten long-term fiscal sustainability and economic prospects, especially given the need to accommodate the increased demands on public health and retirement systems from an aging population. They therefore welcomed the authorities' recognition of the importance of fiscal consolidation, including entitlement reform. With buoyant revenues supporting deficit reduction, most Directors suggested that the time is opportune to establish a more ambitious medium-term fiscal anchor. In particular, they noted that balancing the budget, excluding the Social Security surplus, within the next five years would set the federal debt ratio on a firm downward path. This would reduce the burden on future generations of providing health care and retirement income to the baby boom generation, while also providing the needed room to develop and phase in the reforms required to place entitlement systems on a more sustainable basis. It was observed that this would require consolidation of around $3 / 4$ percentage point of GDP a year. Such consolidation would provide a helpful boost to national saving and multilateral efforts to narrow global imbalances while having a manageable impact on U.S. and global demand. A few Directors cautioned that too rapid a fiscal consolidation could lower U.S. and global growth.

Several Directors observed that planned expenditure discipline may be difficult to sustain, especially in light of pressures to fund defense commitments and other emergency priorities. To help contain spending pressures, these Directors suggested there could be merit in reintroducing caps on discretionary outlays, as well as pay-as-you-go (PAYGO) requirements covering both entitlement spending and tax measures.

Although controlling outlays should remain central to deficit reduction, most Directors suggested that revenue measures should not be ruled out. They cautioned that it may be difficult to sustain the significant reductions in marginal tax rates of recent years while meeting the fiscal burden from population aging. They agreed that the priority should be on reforms that broaden the revenue base by reducing tax preferences, including those for mortgage interest payments, employers' contributions to health insurance plan premiums, and state and local tax payments, as suggested by the President's Advisory Panel. A number of Directors also agreed that consideration could be given to consumption-based indirect taxes-such as a national sales tax, a VAT, or energy taxation-that would maintain revenue buoyancy as workers retire.

Directors stressed the importance of re-invigorating the momentum for entitlement reform, and welcomed the proposed bipartisan commission to review this issue, which will be tasked with preparing proposals for reforming all three major entitlement programs to address future 
shortfalls. They noted that useful reform options have already been suggested-including for "progressive price indexation"-and that the key challenge now is to build the necessary consensus around a package of measures that would place the Social Security system on a more sustainable basis. However, concrete proposals will also be required to address Medicare and Medicaid funding gaps, especially given that with the addition of the new prescription drug benefit, the financial shortfall of the Medicare system dwarfs that of Social Security. While highdeductible health plans and other measures may help improve incentives, with health spending as a ratio-to-GDP well above the OECD average, Directors suggested that fundamental reform of the U.S. health care system would seem to be necessary.

At a more systemic level, and in light of the high U.S. current account deficit, Directors noted the risks in the medium term of a disorderly unwinding of global imbalances. While several Directors considered such risks to be relatively low, Directors agreed that the United States has a key role to play in supporting the cooperative strategy for an orderly resolution of global imbalances laid out by the International Monetary and Financial Committee in April 2006. In particular, they underscored the importance of boosting U.S. national saving, through ambitious fiscal consolidation, while also preserving the resilience and flexibility of the U.S. economy. Directors also generally considered that delaying the inevitable adjustment would mean continued increases in U.S. external indebtedness, and heighten the risk of a sharp disruption to exchange rates, financial markets, and growth—both domestically and abroad. In this context, they looked forward to the results of the multilateral consultations surveillance initiative, for the U.S. and other participating countries.

Directors agreed that leadership by the United States remains key to global trade liberalization, especially given the growing urgency of achieving an ambitious conclusion to the Doha Round negotiations. At the same time, most Directors cautioned that care would be needed to resist domestic protectionist sentiment and to ensure that bilateral trade initiatives complement rather than substitute multilateral approaches. While welcoming recent increases in U.S. overseas development assistance, Directors called on the authorities to boost such assistance further, noting that it remains one of the lowest among industrial countries as a proportion of gross national income.

Public Information Notices (PINs) form part of the IMF's efforts to promote transparency of the IMF's views and analysis of economic developments and policies. With the consent of the country (or countries) concerned, PINs are issued after Executive Board discussions of Article IV consultations with member countries, of its surveillance of developments at the regional level, of post-program monitoring, and of ex post assessments of member countries with longer-term program engagements. PINs are also issued after Executive Board discussions of general policy matters, unless otherwise decided by the Executive Board in a particular case. 
Table 1. United States: Selected Economic Indicators

(Annual change in percent, unless otherwise noted)

\begin{tabular}{|c|c|c|c|c|c|c|c|}
\hline & 1999 & 2000 & 2001 & 2002 & 2003 & 2004 & 2005 \\
\hline \multicolumn{8}{|l|}{ NIPA in constant prices $1 /$} \\
\hline Real GDP & 4.4 & 3.7 & 0.8 & 1.6 & 2.7 & 4.2 & 3.5 \\
\hline Net exports $2 /$ & -1.0 & -0.9 & -0.2 & -0.7 & -0.5 & -0.7 & -0.3 \\
\hline Total domestic demand & 5.3 & 4.4 & 0.9 & 2.2 & 3.0 & 4.7 & 3.6 \\
\hline Final domestic demand & 5.4 & 4.5 & 1.8 & 1.8 & 3.0 & 4.4 & 3.9 \\
\hline Private final consumption & 5.1 & 4.7 & 2.5 & 2.7 & 2.9 & 3.9 & 3.5 \\
\hline Public consumption expenditure & 3.1 & 1.7 & 3.1 & 4.3 & 3.0 & 2.1 & 1.5 \\
\hline Gross fixed domestic investment & 8.2 & 6.1 & -1.7 & -3.5 & 3.3 & 8.4 & 7.2 \\
\hline Private & 8.3 & 6.5 & -3.0 & -5.2 & 3.6 & 9.7 & 8.1 \\
\hline Public & 7.5 & 3.6 & 4.9 & 5.1 & 2.0 & 2.3 & 3.0 \\
\hline Change in business inventories $2 /$ & -0.1 & -0.1 & -0.9 & 0.4 & 0.0 & 0.3 & -0.3 \\
\hline GDP in current prices $1 /$ & 6.0 & 5.9 & 3.2 & 3.4 & 4.8 & 7.0 & 6.4 \\
\hline \multicolumn{8}{|l|}{ Employment and inflation } \\
\hline Unemployment rate (percent) & 4.2 & 4.0 & 4.7 & 5.8 & 6.0 & 5.5 & 5.1 \\
\hline CPI inflation & 2.2 & 3.4 & 2.8 & 1.6 & 2.3 & 2.7 & 3.4 \\
\hline GDP deflator & 1.4 & 2.2 & 2.4 & 1.7 & 2.0 & 2.6 & 2.8 \\
\hline \multicolumn{8}{|l|}{ Financial policy indicators } \\
\hline Unified federal balance (billions of dollars) & 126 & 236 & 128 & -158 & -378 & -413 & -318 \\
\hline In percent of FY GDP & 1.4 & 2.4 & 1.3 & -1.5 & -3.5 & -3.6 & -2.6 \\
\hline General government balance (NIPA, billions of dollars) & 79 & 159 & -39 & -397 & -543 & -554 & -478 \\
\hline In percent of CY GDP & 0.9 & 1.6 & -0.4 & -3.8 & -5.0 & -4.7 & -3.8 \\
\hline \multicolumn{8}{|l|}{ Balance of payments } \\
\hline Current account balance (billions of dollars) & -300 & -415 & -389 & -472 & -528 & -665 & -792 \\
\hline In percent of GDP & -3.2 & -4.2 & -3.8 & -4.5 & -4.8 & -5.7 & -6.3 \\
\hline Merchandise trade balance (billions of dollars) & -346 & -452 & -427 & -482 & -547 & -665 & -783 \\
\hline In percent of GDP & -3.7 & -4.6 & -4.2 & -4.6 & -5.0 & -5.7 & -6.3 \\
\hline Invisibles (billions of dollars) & 46.2 & 37.3 & 38.2 & 9.86 & 19.8 & 0.12 & -8.8 \\
\hline In percent of GDP & 0.5 & 0.4 & 0.4 & 0.1 & 0.2 & 0.0 & -0.1 \\
\hline \multicolumn{8}{|l|}{ Saving and investment (as a share of GDP) } \\
\hline Gross national saving & 18.1 & 18.0 & 16.4 & 14.2 & 13.4 & 13.4 & 13.4 \\
\hline Gross domestic investment & 20.6 & 20.8 & 19.1 & 18.4 & 18.5 & 19.6 & 20.1 \\
\hline
\end{tabular}

Source: Haver Analytics; and IMF staff estimates.

1/ National accounts data as available at the time of the July 24, 2006 Executive Board discussion.

2/ Contribution to growth. 